OBS-Arbeitsheft 103

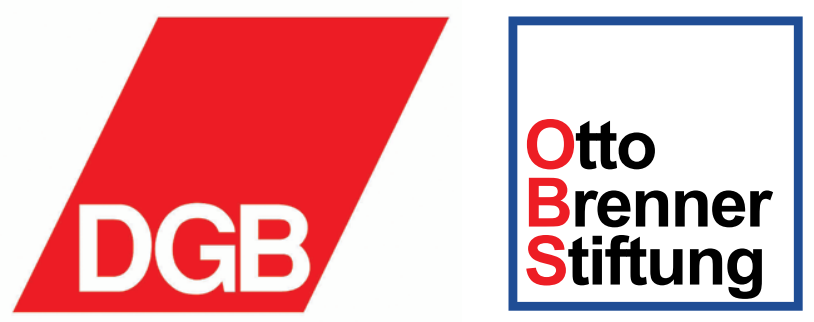

Alexander Fanta/Ingo Dachwitz

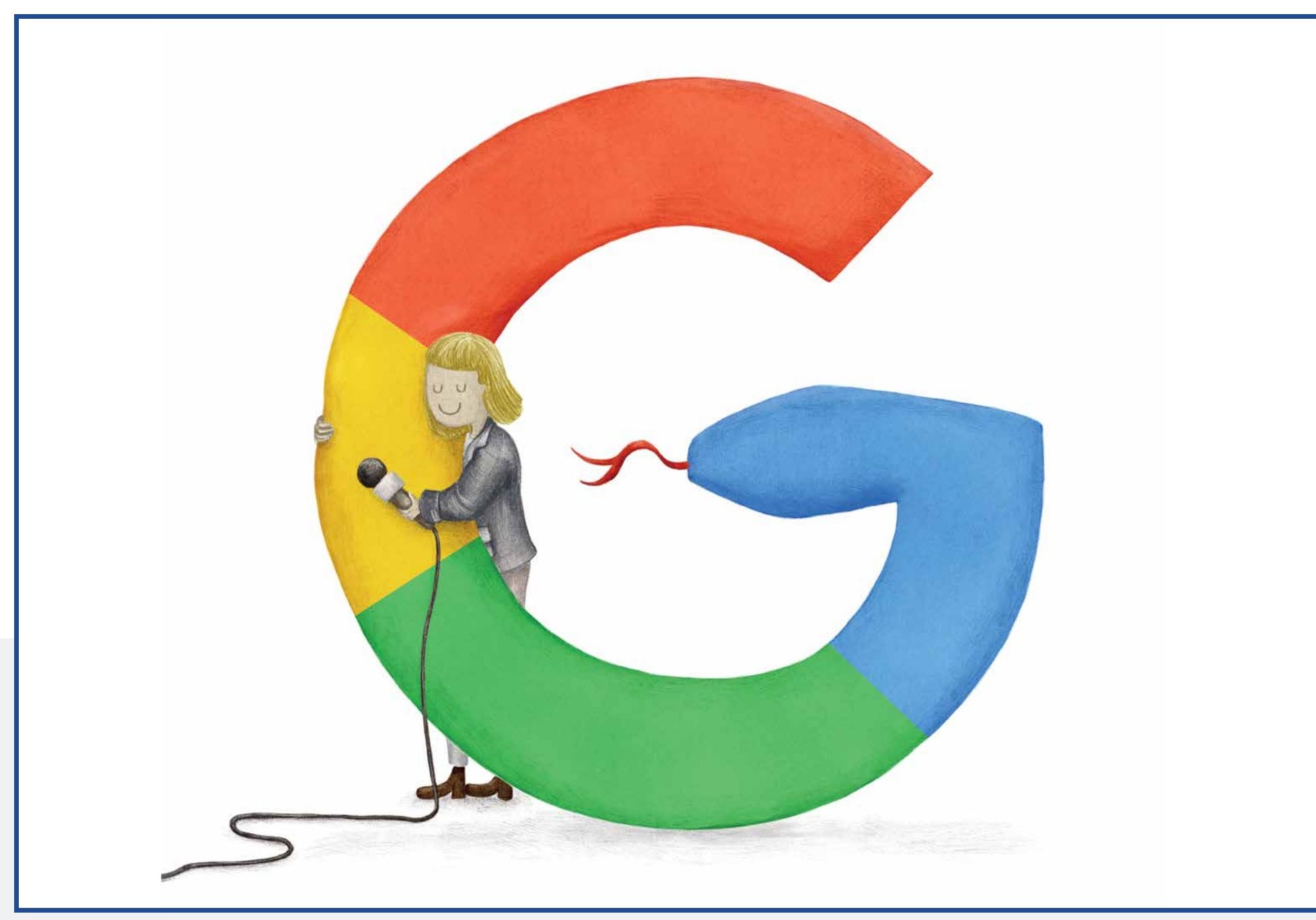

\title{
Google, the media patron
}

How the digital giant ensnares journalism

A project of the Otto Brenner Foundation (OBS) Frankfurt am Main 2020 


\section{Publisher:}

Otto Brenner Foundation (OBS)

Jupp Legrand

Wilhelm-Leuschner-Straße 79

D-60329 Frankfurt am Main

Tel.: 069-6693-2810

Fax: 069-6693-2786

E-Mail: info@otto-brenner-stiftung.de

www.otto-brenner-stiftung.de

In cooperation with the

German Trade Union Confederation (DGB).

Authors:

Alexander Fanta

Siebenbrunnengasse 18/1/9

\section{A-1050 Wien}

E-Mail: alexander.fanta@netzpolitik.org

Ingo Dachwitz

c/o netzpolitik.org

Schönhauser Allee 6/7

D-10119 Berlin

E-Mail: ingo.dachwitz@netzpolitik.org

Both authors contributed equally to this study.

Editing and Project Management:

Benedikt Linden (OBS)

Pauline Frankenberger (OBS)

Marion Knappe (DGB)

Design: thinkandact-mainz.de

Translation: lingolinx.de

Cover: Kwennie Cheng

Editorial deadline: 28 July 2020

We would like to thank the Hans Böckler Foundation for the Support in publishing “OBS-Arbeitsheft 103”.
Terms of use:

This publication may only be passed on - as well as made publicly available - by third parties for non-commercial purposes in the field of scientific research and advice. This may be done exclusively in the version published by the Otto Brenner Foundation and the DGB.

The "OBS-Arbeitshefte" document the results of the Otto Brenner Foundation's research funding and make them available to the public. The authors are responsible for the content. 


\section{Contents}

1 Introduction: an unprecedented charm offensive

3

2 The newspaper crisis and its consequences .......................................................... 6

2.1 Press independence in the market economy..........................................................6

2.2 Google in good company: the new patrons of the media .........................................9

2.3 Platforms and publishers: competition or cooperation? ............................................... 12

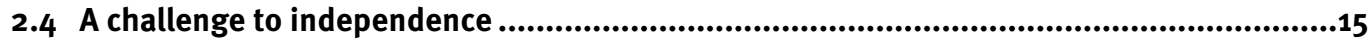

2.5 Interim summary: three dimensions of press independence......................................... 18

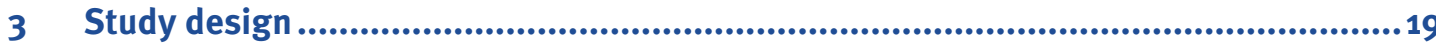

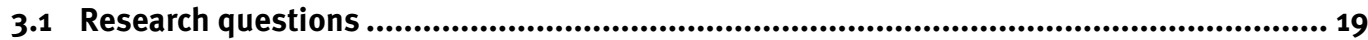

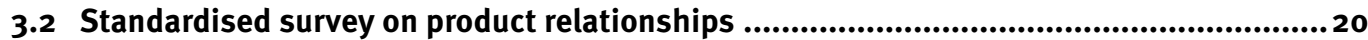

3.3 Digital News Innovation Fund data analysis............................................................ 21

3.4 Guided interviews with digital journalists and managers ...........................................23

3.5 Interview with Google managers ........................................................................... 26

4 History and structure of Google's news initiatives ..................................................27

4.1 A political backdrop.............................................................................................28

4.2 Google's European funding operations: the Digital News Initiative (DNI)...................... 31

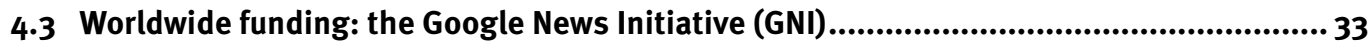

4.4 Philanthropy and self-interest ............................................................................ 35

4.5 Interim summary: funding programmes under political auspices ................................ 37

$5 \quad$ Media funding with the Digital News Innovation Fund.......................................... 39

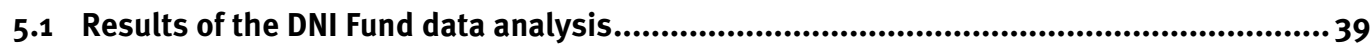

5.2 How DNI projects work in practice .......................................................................51

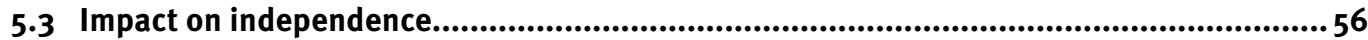

5.4 Interim summary: Google's millions for the media industry are not without consequence 
6 Conferences, training, fellowships ................................................................... 66

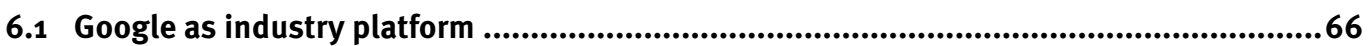

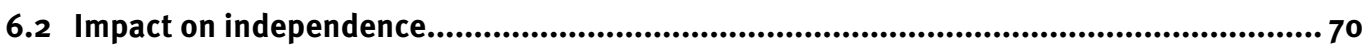

6.3 Interim summary: "community building” powered by Google .............................................. 72

$7 \quad$ Economic and technological ties ................................................................................74

7.1 Google's services as infrastructure for the industry........................................................... 74

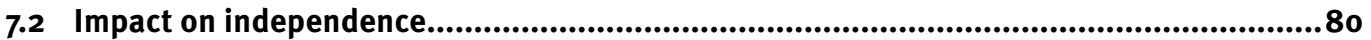

7.3 Interim summary: Google services are frequently essential .............................................83

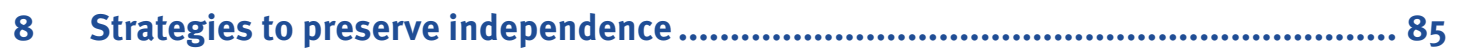

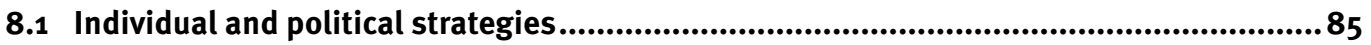

8.2 Interim summary: scant (institutionalised) protections against conflicts of interest ........87

9 Summary and outlook..................................................................................... 89

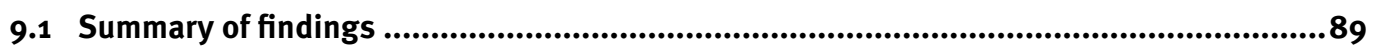

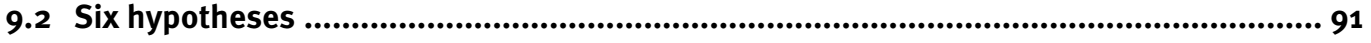

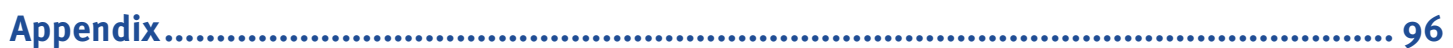




\section{Introduction: an unprecedented charm offensive}

Back in 1994, Der Spiegel was the first major German news organisation to launch a website. More than a quarter of a century later, the digital transformation process in the industry remains far from complete. Advances in technology are fundamentally changing how journalism is produced, disseminated, and consumed, but many news publishers have still not found an effective way to lastingly offset their falls in print revenues with digital content. Frequent management restructuring at newspaper publishers is testament to the confusion and uncertainty that the major changes of recent years have brought about.

It is perhaps ironic, then, that the company coming to the rescue of the battered "fourth estate" is the one seen as applying the most pressure on the media to go digital: Google, the global corporation lauded as an innovative model by journalists in the 2000 s but increasingly the subject of media criticism since the 2010 s (see Trautner 2014). With its Digital News Initiative (DNI), the tech company opened a new chapter in its previously often strained relationship with the European publishing industry. Since 2013, Google has funded European journalism to the tune of over 200 million euros. The corporation has given no-strings grants to hundreds of media companies, startups, individuals, and research institutions throughout Europe to engage in innovation projects. It also organises journalism conferences and finances fellowships for young journalists at respected news organisations.

It is these Google-funded fellowships that provided the impetus for the present study.
Co-author Alexander Fanta spends six months of 2017 at the Reuters Institute for the Study of Journalism at the University of Oxford; in the autumn, he spends time working in the Digital Product Development department of the Neue Zürcher Zeitung. Both of these stays are funded by Google. The question "What does Google get out of it?" is the starting point for several months of research that the authors of the study publish jointly on netzpolitik.org (in German) and in the European Journalism $\mathrm{Ob}$ servatory (in English) (Fanta/Dachwitz 2018).

Google came to the media with funding, training programmes, and conferences, but the ensuing dialogue has gone far beyond the company's own products and its business relationships with news publishers to encompass the all-important question of the form innovation and new business models in journalism will take. Google's various forms of sponsorship ensure that the company always has a say in debates regarding the future of the news media.

And Google is also filling a gap that no-one else is. "Journalism needs all the support it can get," says Alexandra Borchardt, former managing editor of the Süddeutsche Zeitung (International Journalism Festival 2019). Borchardt is now a journalism professor at the Reuters Institute at the University of Oxford, which since 2015 has itself received over a million pounds from Google annually for its study on the use of digital media. Her comment was made in 2019 at the International Journalism Festival in Perugia, a prestigious industry event that counts Google as one of its primary sponsors. 
Borchardt's view is widely shared in the industry: the 92 recipients of Google funding in Germany include leading publishers such as the Frankfurter Allgemeine Zeitung, Der Spiegel, Zeit Online, the Funke Mediengruppe, DuMont, and Gruner + Jahr. Smaller and regional media organisations have also received occasional funding for innovation projects from Google, including the taz, the Tagesspiegel, the Rheinische Post, and the state-financed Deutsche Welle. In Germany alone, Google provided 21.5 million euros of funding from its DNI Fund for media projects from 2016 to 2019.

Over these years, this money has helped to transform business models in the German media landscape. A number of larger news publishers now feel confident that they will in future be able to generate a substantial share of their revenues from paid online content. When it comes to journalism's financial situation, the corona pandemic deals a heavy blow to the media in early 2020 . And who should be there with millions of euros in financial support? None other than Google and Facebook.

The close ties that tech corporation Alphabet and its subsidiary Google maintain with the news industry are, however, not just about money. Technology is also a crucial aspect after all, publishing on the internet is practically unthinkable without Google. Without the infrastructure provided by the corporation, most web users would find it impossible to find what they are looking for. Google's dominant market position allows it to shore up its online supremacy with advertising and the corporation's Android operating system, which is installed on the vast majority of smartphones worldwide. Given this market position, the company's business decisions have an impact on everyone who publishes content on the internet. News media are practically compelled to use Google's services.

The funding programmes that Google first trialled in France, and later throughout Europe in the form of the DNI, have now gone global: for the period from 2019 to 2021 alone, the company has committed a further 300 million dollars of funding for journalism. There is little doubt that this makes Google the world's biggest patron of journalism. Much of the involved money, however, flows from the corporation to other profit-making companies - an enormous, unparalleled transfer of cash with no apparent return.

So what is Google's motivation for supporting journalism? And what is the significance of the corporation's growing influence on the independence of the news media, many of which in Europe still see themselves as the "fourth estate" in democratic discourse? These questions have to date received scant scholarly attention.

This study examines Google's relationship with the German media. Chapter 2 sets out the context of this relationship and discusses the economic crisis facing the news media, the opportunities and issues surrounding new sources of funding, such as foundations, and present ties between the media and tech industry. Chapter 3 goes on to describe the methodology of the study, which is based on an analysis of data from over 600 Google- 
funded projects, interviews with 25 German publishing managers and digital journalists, and a survey on the use of Google services by media companies. Google's Europe-wide support of the media, i.e. the Digital News Initiative that issued grants from 2016 to 2019, is also subjected to empirical evaluation. Chapter 4 explains the programme's political background and traces the development of Google's media funding operation, all the way from a 60-million-euro fund in France back in 2013 to today's 300-million-dollar Google News Initiative (GNI). Chapter 5 analyses the distribution of innovation funds through the DNI Fund organised by the European Digital News
Initiative from 2016 to 2019 and explains their significance to technological development at German media companies on the basis of interviews. Chapter 6 examines the role of Google's funding in training at media companies and networking within the industry. Chapter 7 sheds light on the technological and economic links between Google and German media companies, in part using as its basis a survey of 22 German media companies. In Chapter 8, the authors then take the interviews they conducted as the basis for discussing the frequent lack of protections from Google's growing influence on the media industry, before drawing their conclusions in Chapter 9. 


\section{The newspaper crisis and its consequences}

The crisis facing the German news industry is now in its third decade. Since no later than the late 1990s, when the internet became a fixture in most German households, reading and media consumption habits have been in a constant state of flux. Technical advances are disrupting journalism's production and distribution processes, and a sustainable digital business model is still proving elusive to many news media organisations. Hopes that the lack of circulation revenues for online journalism could be offset by increasing reach through advertising have not materialised at the majority of these companies (Hanitzsch et al. 2019: 9 f.).

The search for successful digital business models is all the more pressing in light of the continuing downward trend in the print business: "The circulation and reach of daily German papers have been in steady decline for at least two decades," according to a study conducted at the University of Hohenheim in 2019 (Mast et al. 2019: 21). Actual closures of national media organisations such as the Financial Times Deutschland or the news agency dapd - both in 2012 - may be fairly rare, but the print circulation of local and regional subscription newspapers in western Germany fell from 14 million in 1995 to 9.6 million in 2017. Some 12 percent of papers were discontinued or lost their independence. Local newspapers, in particular, saw young readers turn away (ibid.).

It is not just the raw numbers, however, that make for grim reading. The crisis narrative has also dominated the industry and how it sees itself for many years: in this context, the economic crisis (see Weichert et al. 2014: $31 \mathrm{ff}$.) may be joined by the crisis of confidence (see Heim 2019) and a perceived crisis of press freedom (see Wolf 2018). What are the possible consequences of this trend?

\subsection{Press independence in the market economy}

The role of news media in liberal democracies is sometimes, as mentioned above, referred to as the "fourth estate," acting as a corrective "that assumes a public watchdog role over the integrity and appropriateness of the three branches of government," (Bidlo 2012: 151) the executive, the judicial, and the legislative. Even if the media cannot technically be equated with these three traditional branches, its freedom and independence are considered a bedrock of liberal democracy: “Editorial independence is an essential element of professional journalism. Journalists can only fulfil their public duty if they are allowed to work independently of others' personal or business interests and their own economic interests" (Meier 2013:16).

Since the very beginnings of modern journalism, this independence has been complicated by the conflict between press and economic interests: journalism needs to be financed. It is considered a "merit good" (see Weischenberg 2018: 51), meaning that it is a commodity which is judged a society should have on the basis of some concept of need, rather than willingness to pay. Only in exceptional cases could journalism be financed by subscriptions alone. 
For print newspapers, cross-financing with advertising has thus become the established model: throughout most of the 2oth century, it acted as a dependable method of newspaper financing alongside regular sales revenues (see Beck 2012: 112). That this was always a potential source of friction with the principle of editorial independence can be seen in a critique by economist Karl Bücher from 1917: the newspaper "sells news to its readers, and at the same time it sells its circle of readers to any private interest capable of paying the price" (Bücher 1917, cited in Beck 2012: 112).

The German press is largely itself responsible for ensuring that conflicts of interest do not arise and that the necessity of publishers financing journalists' work does not serve to curtail editorial independence. Germany's Basic Law guarantees the freedom of the press. As a historical lesson learned from the horrors of national socialism and other authoritarian regimes, the state's influence over the media in Germany is to be kept to a minimum: "The constitutionally guaranteed freedom of communication and media means [...] abrogating any kind of direct control over media products and those who produce them," as Weischenberg puts it (2018: 225).

While it is true that there are public regulatory frameworks in Germany - the state press laws that stipulate special rights and due diligence obligations, together with merger control procedures and court rulings on press law - beyond actionable offences it is left to the German Press Council, the body responsible for enforcing the voluntary self-regulation of the press, to monitor compliance with ethical rules in the industry. The industry's self-regulation and the critical scrutiny of the media by scholarly institutions and civil society are therefore of particular importance to the independence of journalism.

Despite this, there are still often misgivings about whether this form of self-control functions adequately. As media scholar Nicola Pointner notes in her thesis (2010: 38, 128f.), economic pressure results in increasing market concentration and economic ties between media corporations, which at the same time are becoming less and less transparent to the outside world. Pointner's work focuses on the blind spots in German media journalism, and she clearly demonstrates how press publishers act like political actors whose economic self-interest hinders critical reflection of their business relationships: “Internal press freedom [i.e. the newsroom's independence from the publisher; authors' note] is subtly but immensely diminished, and editorial independence is jeopardised, by the dependencies on the interests and participations of publishers" (Pointner 2010: 370).

\section{An industry under pressure}

The ongoing sense of crisis within the media is now threatening to upset the already delicate balance of press and economic interests. It has already been around 10 years since the pressure to lower costs and accept change began to mean reduced budgets and staff cuts in newsrooms (see Buschow et al. 2011). Precarious journalism jobs have since become 
more common; competitive pressure among salaried journalists is growing (Hanitzsch et al. 2019: 234). Widespread job insecurity is no longer merely a niche issue affecting the fringes of the profession, but now goes to the very heart of journalism in Germany, as Thomas Schnedler notes in his thesis on the subject (Schnedler 2017: 237).
This has consequences for journalists' perceived freedom of expression and independence. A survey of 2,500 journalists in Germany, Austria, and Switzerland conducted in 2014 and 2015 found that German journalists feel the economic influence of external actors, managers, and owners more strongly than journalists in the other two countries. They are

\section{$\S$ Excerpts from the Press Code}

The Press Code compiled by the German Press Council addresses potential economic interference in editorial independence at two points.

Section 7 - separation of advertising and editorial content:

"The responsibility of the press towards the general public requires that editorial publications are not influenced by the private or business interests of third parties or the personal economic interests of the journalists. Publishers and editors must reject any attempts of this nature and make a clear distinction between editorial and commercial content. If a publication concerns the publisher's own interests, this must be clearly identifiable."

(German Press Council, 2017)

Section 15 - preferential treatment:

"The acceptance of privileges of any kind that could possibly influence the freedom of decision on the part of publishers and editors is irreconcilable with the prestige, independence, and responsibilities of the press. Anyone accepting bribes for the dissemination of news acts in a dishonourable and unprofessional manner.

Even the appearance that the freedom of decision of a publishing house and its editorial staff can be impaired is to be avoided. Journalists shall therefore not accept any invitations or gifts whose value exceeds the extent that is usual in business and necessary as part of working life. The acceptance of advertising articles or other low-value objects is harmless.

Research and reporting must not be influenced, hindered or even prevented by the accepting of gifts, invitations or discounts. Publishing houses and journalists shall insist that information be given regardless of the acceptance of a gift or an invitation. If journalists report on press trips to which they have been invited, they shall make this financing clear."

(German Press Council, 2017) 
"therefore possibly a little more cautious in how they rate their discretionary freedom" (Laurer/ Keel 2019: 246). Around a fifth of German journalists see profit expectations as having a strong influence on their autonomy (ibid.: 131). This confirms earlier findings that, from the perspective of journalists, media coverage in Germany is more often influenced by economic than by political considerations (ibid.).

Elsewhere, too, there are increasing signs that economic pressure is negatively impacting on editorial independence. In line with Section 7 of the German Press Code (see box), most publishers strictly separate the work of their advertising department from the newsroom in order to avoid advertising customers influencing their content. But as earlier studies by the Otto Brenner Foundation on event cooperations between publishers and lobby organisations (see Oppong 2016) and on the spread of content marketing in the media (see Frühbrodt 2016) reveal, these "firewalls" that aim to prevent economic influence have become somewhat porous. In his study, which takes as its example event cooperations, Oppong argues that "they may create opportunity structures that serve to align the interest of journalists and lobbyists, or otherwise limit a critical perspective” (Oppong 2016: 32).

For the US, communication scientist Mark Coddington goes so far as to state that the dominance of the metaphorical "wall" between editorial and advertising departments is a thing of the past (Coddington 2015: $78 \mathrm{f}$.). In his view, their strict separation must be regarded as historical and does not stand up to empirical scrutiny in today's world. Nevertheless, he still sees the performative practice of demarcating editorial and business interests as an important element in journalists' professional identities. Now, he states, there is a need to replace the "wall" with a robust set of standards to ensure that journalists retain their professional integrity and autonomy in the face of economic interests and a sceptical public (ibid.).

\subsection{Google in good company: the new patrons of the media}

While contending with the issues set out above, the journalism business's financing shortfall brings a new group into the spotlight. Over the past decade, tech companies and their founders have spent billions on the media, mostly in the US but also occasionally in Asia and in Germany.

Tech entrepreneurs' financing of journalism and the media can be split into three broad categories:

- personal ownership of media organisations

- foundation funding

direct grants

\section{Personal ownership}

Probably the best-known example of a tech entrepreneur becoming involved in the day-today business of publishing was when Amazon founder Jeff Bezos acquired the Washington Post. In 2013, Bezos paid 250 million dollars to buy the economically faltering yet politically influential paper. Critics were concerned that the newspaper might be used to further Bezos's own interests and company, and although there has not actually been much evidence of 
any such influence, the issue has come up time and time again, most recently in the wake of an editorial in spring 2019 that criticised a tabloid for publishing sensational revelations about the Amazon owner's sex life (Lee 2019).

Other acquisitions followed in Bezos's footsteps. In 2017, Laurene Powell Jobs, the widow of Apple founder Steve Jobs, acquired a majority stake in The Atlantic magazine through her non-profit organisation Emerson Collective. Shortly thereafter, billionaire Patrick SoonShiong, a man who made his fortune with biotechnology in the US, bought the L.A. Times for 500 million dollars. The founder of the US software company Salesforce, Marc Benioff, and his wife Lynne Benioff acquired Time magazine for 190 million dollars in 2018 (see Montag 2018).

Less successful, by contrast, was an earlier attempt to enter the industry by Facebook co-founder Chris Hughes, who bought the political magazine The New Republic in 2012. Hughes sold the magazine just four years later, having lost millions (Somaiya 2016). Elon Musk had a similar experience. The Tesla founder originally considered acquiring the satirical paper The Onion, but then decided to launch his own site. The Thud project would set new standards for satire, but folded after just one year (Kastrenakes 2019).

Acquisitions of media companies are, however, not unique to tech entrepreneurs from the US. Across the Pacific, the founder of the Chinese online retail giant Alibaba, Jack Ma, purchased the South China Morning Post, placing this respected Hong Kong-based newspaper in the hands of a billionaire with close ties to the Chinese government in Beijing. In an interview with his own paper, Ma rejected "stereotypes" of China in the western press (Chow 2016), and critics note that the paper's coverage of China has since become noticeably more friendly (Hernández 2018). Other wealthy people in the industry emulated Ma in mainland China, buying newspapers and reshaping the Chinese press landscape, as a former journalist for the South China Morning Post reports in a paper for the Reuters Institute for the Study of Journalism (see Lee 2018).

In Germany, Silke and Holger Friedrich hit the headlines in September 2019 when they purchased the BerlinerVerlag publishing house. The couple, who were previously unknown names in the media industry, had made their fortune with software companies and technology consulting (Meier 2019). The Berliner Verlag publishes titles such as the Berliner Zeitung and the Berliner Kurier. Many other media organisations took a dim view of the acquisition, largely focussing their ire on Holger Friedrich personally, in particular due to his work in the 1980 s as an unofficial collaborator for the Stasi in the former East Germany (see Hensel 2019). In the light of several favourable articles on topics, products, and companies that overlap with the couple's own business interests that appeared in their own papers in autumn 2019, criticism, however, has also been directed at the potential impact on the publisher's editorial independence (see Grieß 2019).

\section{Foundation funding}

Technology billionaires have a longer history of foundation-funded journalism. The Bill and Melinda Gates Foundation, financed by the 
Microsoft founder's assets, funds media coverage on healthcare and development issues as well as training for journalists. Since 2002, the Gates Foundation has provided grants to dozens of organisations; as an example, it financed the Guardian's reporting on global development for almost a decade. The 75 funding approvals published on the Gates Foundation website under the search term "journalism" by March 2020 are worth a total of some 63.5 million dollars (Gates Foundation 2020).

Another example is eBay founder Pierre Omidyar, who announced an investment of 250 million dollars in non-profit journalism in the autumn of 2013. For his first project, he co-founded The Intercept, an investigative online publication, together with NSA whistleblower Glenn Greenwald. Further start-ups within the non-profit section of Omidyar's dedicated publishing house First Look Media, however, failed or were shelved after only a short time; former employees report poor management and money being wasted (see Silverstein 2015; Davis 2019). In 2017, Omidyar again promised to invest 100 million dollars to foster investigative journalism and fight hate and disinformation on the internet, to be paid out through Omidyar's foundation network, now renamed Luminate. It is unclear, however, how much of this money actually went to support journalism. According to a calculation by the Columbia Journalism Review, First Look Media was financed to the tune of around 90 million dollars between 2013 and 2017, but much of the promised funds are yet to be released (see Davis 2019).

Another major benefactor of journalism is Craig Newmark. The platform he founded,
Craigslist, is a popular classified ad site in the US. One study estimates that Craigslist's competition in the classified ads market alone cost American newspapers five million dollars in sales between 2000 and 2007 (see Seamans/ Zhu 2013). While Newmark denies that his company has any part to play in the demise of American newspapers, he donates millions to journalism institutes and media organisations through his foundation Craig Newmark Philanthropies by the end of 2018 alone, he had committed to grants worth 50 million dollars (Streitfeld 2018). In Europe, for example, the International Journalism Festival in Perugia was awarded funds from Craig Newmark Philanthropies.

The Newmark foundation also helped to found a media organisation, gifting The Markup with 20 million dollars. The news site, established in $\mathbf{2 0 1 8}$, is dedicated to investigative technology reporting, but initially suffered from teething problems. After a disagreement between editor-in-chief Julia Angwin and Sue Gardner, who was in charge of business matters on the project, The Markup did not publish its first articles until February 2020 (see Ingram 2019a; Tracy 2020).

The problems at The Markup and the organisations founded by First Look Media clearly reveal that technology patrons' start-ups, regardless of the money they pump into them, do not always run smoothly.

\section{Direct grants from technology companies}

Google takes a different approach with its direct funding for journalism, which is the primary subject of this study. The US corporation's News Initiative is also a model picked up 
by competitor Facebook, which now has its own funding programme, the Facebook Journalism Project. In January 2019, Facebook committed 300 million dollars primarily to support local journalism, according to the company, and announced major donations to non-profit organisations such as the Pulitzer Center (Ingram 2019b). In its first cooperation in Germany, Facebook has been funding a training programme for digital journalists at the Hamburg Media School since 2018 (Bouhs 2018).

Facebook's initiative is based on three key pillars: financial grants, training for journalists, and "partnerships" with publishers and other organisations. The descriptions listed on the website reveal that many of the projects aim to integrate news content in the social network. The Facebook Journalism Project presents as a "success story" a partnership with $B B C$ News that resulted in the news site of the British public service broadcaster growing its account on Facebook's Instagram platform "from 4.4 million to 10 million followers" (Eyears 2019). The Journalism Project also offers the media how-to guides explaining ways to monetise video content or boost subscription numbers by placing advertisements on the platform.

In doing so, Facebook is building on earlier partnerships. For a while, the company paid some media companies money to publish live videos on the social network. These partnerships brought in up to 200,000 euros a month for a selected group of news organisations and individuals (Becquet 2017); Facebook, however, ended the multi-million-dollar cooperation with its US partners at the end of 2017 , with media reports stating that the company now wanted to compensate news media organisations exclusively through an ad-share model as used on YouTube (see Patel 2017; Jacobsen 2017).

Aside from founder Gates's philanthropic interests, Microsoft operates Bing, a search engine with a separate news search feature. With Microsoft News, the corporation also maintains its own news aggregator site. In May 2020, Microsoft announced that it would be using artificial intelligence to select news stories; 27 journalists who previously carried out this work would lose their jobs (Waterson 2020). On its career network LinkedIn, Microsoft is now engaged in small-scale competition with traditional media organisations: since 2011, LinkedIn has been producing and delivering to users its own news items on economic issues, and by 2019 had 65 people working in its newsroom (Flynn 2019). Microsoft itself has to date only provided occasional assistance to news organisations. One example is the company's sponsorship of several six-month data journalism projects that it funded at the International Center for Journalists from early 2019 to early 2020 (see Shaw 2019, ICFJ 2020).

\subsection{Platforms and publishers: competition or cooperation?}

While tech companies and their owners are increasingly keen to present themselves as sponsors of the beleaguered news media, researchers point out that they, too, are partially responsible for the industry's money problems. Facebook and Google in particular, the platform companies key to the web's attention 
and advertising economy, are at times in direct competition with press publishers.

“[W]hen leading German media managers now say that their biggest digital competitors are essentially the major platform corporations such as Google, Facebook, and Amazon, it sounds almost like a platitude," finds a report compiled on behalf of the German Commission on Concentration in the Media (KEK) (Lobigs/ Neuberger 2018: 140). Publishers need to seek out the niches in their businesses that have not yet been exploited by the web companies, write the report's authors, who add that the central role of digital strategies at media companies can today be "at heart understood as a defensive or sometimes even creative corrective to the growth of disruptive competition [...] that has arisen from the internet's platform revolution" (ibid.: 141).

Google and Facebook's dominance of the online ad market is squeezing out publishers, who are themselves unable to generate sufficient income from advertising for their editorial work. "Based on reliable estimates, the online ad market in Germany is dominated by the duopoly of Google and Facebook, who combined likely accounted for more than three quarters of the market in 2017" (ibid.: 165).

At the same time, hopes of generating greater income from subscriptions at many publishers have not borne much fruit: according to survey data from the Reuters Institute for 2019 , only eight percent of respondents in Germany pay to read news on the internet (Fletcher 2019).

In isolated cases, however, some media companies have succeeded in building new revenue streams, as seen by the growth in event and conference business. Be that as it may, critics point out that publishers have generally failed to react in time to changes to their economic environment and grow their business models, in particular wasting the opportunity to create a sustainable broad-based solution for paid web content. Frederik Fischer, a technology journalist and co-founder of the news curation platform piqd, cites a random survey of readers to explain why so few people are willing to pay for news on the internet. One key reason is the lack of a standardised solution for sign-up and payment among German media organisations, to say nothing of the lack of a flat-rate news service based on models such as Spotify or Netflix (Fischer 2018). This feeling is confirmed by a representative survey of 6,000 media consumers conducted by Christopher Buschow and Christian Wellbrock for the Media Authority of North Rhine-Westphalia, which concludes that digital subscriptions from German news media organisations are often considered too expensive and that users want more transparent pricing structures and simpler payment systems (Buschow/Wellbrock 2019: $6 \mathrm{f}$.).

\section{Dwindling hopes of monetisation} in the platform ecosystem

One scholarly investigation into the relationship between tech companies and news publishers is the "Platforms and Publishers" multiyear project at the Tow Center for Digital Journalism at Columbia University in New York (Rashidian et al. 2018; Rashidian et al. 2019). The study is based on anonymised interviews with representatives of news organisations, plat- 
forms, and a foundation, and examines the relationship between publishers and platforms, with a focus on the changing business models at US publishers. Its conclusions, however, are also relevant to the situation in Europe.

The study's key finding is that publishers' hopes for a sustainable business model within the platform ecosystem have come to nothing (for more on the "ecosystem," see Chapter 4.4). The prospect of sharing in Google and Facebook's advertising revenues to finance journalism has "disappeared". As the authors state, "After years of contradictory public statements, platforms have lost credibility with many publishers" (Rashidian et al. 2019). Instead, there is growing fear of the platform companies making unannounced changes to their products, on which the media publishers are increasingly dependent. One example is the changes Facebook made to its News Feed algorithm in early 2018, which led to a considerable drop in traffic on publishers' websites. The interviewees from news publishers cited in the study also express doubts about the platforms' "free money," which in the US, for example, may take the form of free media advertising on Facebook. "Some newsroom employees wonder whether their companies should accept platform money, and if leading their audiences to platform properties makes them complicit in a harmful information ecosystem." Some respondents frame the journalism initiatives from Google, the focus of the present study, and Facebook as "mere PR moves" (ibid.).

Today's economic threat to the news media's traditional, ad-based business model is "a source of medium or high risk for media pluralism," states a report by the Centre for Media Pluralism and Media Freedom at the European University Institute in Florence (Parcu 2019), which systematically investigates such threats. The concentration of economic power in the hands of technology companies and their growing importance as mediators and gatekeepers of information presents "worrying political implications": "the presence of only a few gatekeepers, and the disappearance of many traditional and local media, may be a driver of excessive standardization and homogeneity of the sources of news and qualified opinions, which thus negatively affects the quality of information" (Parcu 2019: 9). The report notes that the traditional instruments of competition law are insufficient to fix the imbalances in the digital economy (ibid.: 12). One major problem is that EU law is guided by metrics such as a company's revenue, for example in the context of antitrust enforcement to prevent monopolies and the associated restriction of competition. However, the (quasi-monopolistic) control of huge amounts of data, increasingly of relevance today, has to date received little attention.

An earlier study on the relationship between platforms and news publishers originates at the Reuters Institute at the University of Oxford (Kleis Nielsen/Ganter 2017). Based on anonymised interviews with 13 managers from a European media company, it describes the growing influence of platform companies, in particular on the distribution of news content. In their conclusion, the authors state that digital intermediaries such as Google and Face- 
book offer news media organisations "important new opportunities for reaching wider audiences," even if they now have far less control over the distribution of their content than in the past (ibid.: 1614f.). The study also notes that it "remains unclear how the self-interest of digital intermediaries and news media organisations are aligned in the longer term" (ibid.). ${ }^{1}$

\subsection{A challenge to independence}

Complex ties interlink the news media and the major platform companies, the latter of which are at once competitors, infrastructure providers, and subjects of coverage for the media.

From the time of its IPO in 2004, Google has grown to become one of the world's most valuable listed companies today. In recent years, critical media coverage has highlighted privacy failings, breaches of competition law, and tax avoidance tactics, with the US media particularly adept at unmasking Google's misconduct. One example is a report on the news site Gizmodo, which exposed Google's assistance in the development of combat drones by the US Department of Defense (Cameron/ Conger 2018). After its own employees protested, Google shut down the collaboration. A short time later, the New York Times reported allegations that Google had covered up accusations of sexual misconduct against the inventor of the Android operating system, Andy Rubin
(Wakabayashi/Benner 2018). Criticism was again voiced in 2019, this time in light of action taken by the company to thwart attempts by its employees to organise (unionise) (see Wong 2019, Scheiber/Wakabayashi 2019). The company, then, has long ceased to be of interest solely to the business press; it is now frequently the subject of investigative reporting.

Facebook and Google's funding programmes add a further layer to these companies' complex relationships with the media, raising questions about their impact on freedom of expression in the media. As set out in Chapter 2.2, the dialogue and project-based approach to the system of direct grants offered by the tech companies - which Google also practises through its Google News Initiative (see Chapter 3) - is a new phenomenon.

There is currently very little literature on the potential risks to independent reporting associated with Google's money. A glance at more recent writings on foundation funding yields some helpful information on these issues, as this model of financing bears a number of similarities with Google's project funding programmes.

\section{Opportunities and issues in} foundation financing

Some media organisations, especially in the US and the UK, have long been tapping into a new source of money from outside the tra-

1 It is particularly worth noting here that the Reuters Institute - the Director of which is now the study's co-author Kleis Nielsen - had already received millions of pounds in funding from Google at the time the study was published. In the note on "Funding" at the end of the study, Kleis Nielsen and Ganter report only that the project was funded by a Danish society. 
ditional news business: foundation financing. Prime examples include ProPublica in the US or The Bureau of Investigative Journalism in the UK, which chiefly finance their award-winning investigations with foundation money. Other companies, such as the Guardian, accept philanthropic grants for individual projects or sections of a publication. Foundations, in turn, primarily finance quality media and often support coverage in fields that would otherwise receive scant media attention.

The foundation financing model for journalism is not particularly widespread in mainland Europe, even though some organisations, such as the European Journalism Centre, are actively working - with financial support from Google - to popularise it (Thomas 2019). In Germany, the Association of German Foundations reports around 120 foundations that fund news content or projects, although the majority of grants go to journalism awards, training, and conferences, with less emphasis on supporting jobs or research (Kowark 2020: 90). The cited article, written by the Press Spokeswoman of the Association of German Foundations, Katrin Kowark, reveals that calls are growing in Germany for foundation funding in journalism to increase.

The model of foundation financing undoubtedly offers opportunities for a new type of non-commercial journalism, but it, too, is sometimes as equally susceptible to influence as the model of advertising-financed media. A number of new studies from the US show how a commercial focus is being replaced by the agendas of these media patrons (see Benson 2017; Scott et al. 2019; Ferrucci/Nelson 2019), some of whom, as shown in Chapter 2.2, themselves come from the tech industry. Rodney Benson's study analyses the social make-up of foundations and news organisations, and finds that the boards of the non-commercial media organisations he examines are dominated by business professionals and graduates of top US universities. Benson writes that philanthropic support "mostly reinforces and extends an upper middle-class, pro-corporate orientation in mainstream American journalism" (Benson 2017: 2). In his opinion, this has a clear impact on reporting, with media organisations often reliant on project-based funding and at risk of being captured by foundation agendas (ibid.). In a later study that arrives at similar findings, Patrick Ferrucci and Jacob L. Nelson also stress a central difference to the model of financing through advertising: in the case of foundationfinanced journalism, there is no sense of a firewall between newsrooms and foundations, as is at least common in the theory - albeit increasingly flexible in practice - that dictates the separation of editorial work and advertising (Ferrucci/Nelson 2019: 52).

In 2010, Robert Fortner provided an interesting case study on this subject in a twopart article, published in Columbia Journalism Review, on the Gates Foundation, which also finances journalism. As he sets out, not only do the subjects of the articles financed by the foundation coincide with the foundation's key interest in promoting global health; the Bill and Melinda Gates Foundation itself becomes a kind of blind spot in the work of the funded media organisations as they try to avoid criticism of their sponsor (Fortner 2010). 
According to a study by Martin Scott, Mel Bunce, and Kate Wright (2019), however, foundation financing does not influence press independence by directly interfering in journalists' work, but takes effect in a subtler, even unconscious way. As Alan Rusbridger, former editor of the Guardian, writes in his book "Breaking News" (Rusbridger 2018), there is not one form of journalism, but rather a range of competing styles and practices. In the digital age, the boundary of what is considered journalism is thus ever-changing and in a constant state of flux (ibid.: 360).

Scott, Bunce, and Wright's study, based on 74 interviews with representatives of foundations and journalists, considers foundation financing as pushing this very boundary. It stimulates journalists to engage in non-editorial work and encourages them to "focus on producing longer-form, off-agenda news coverage about topics broadly aligned with the priorities of the most active foundations" (Scott et al. 2019: 2035). In the process, foundations are subtle about communicating their priorities. The months and even years of "getting to know each other" that news organisations go through before receiving any grant money results in a form of “alignment” (ibid.: 2041).

It is worth mentioning at this point a key criticism of philanthropy that appears of relevance in connection with the Google News Initiative. Sociologists Aaron Horvath and Walter W. Powell from Stanford University describe the concept of "disruptive philanthropy," a more recent phenomenon with the potential to harm democracy. In contrast to traditional forms of philanthropy, which are guided by needs or interests not catered to by government, disruptive philanthropy champions new causes with large donations to create public goods and influence debate on social issues (Horvath/Powell 2016). As understood by the authors, these philanthropists at least implicitly pursue the goal of shaping new values and exercising pressure to adapt to new, marketoriented approaches. ${ }^{2}$

\section{Google: patron and technology partner}

Research on the influence of foundations on journalism opens up approaches to analysing the special case of Google's (and Facebook's) patronage of journalism. There is a significant parallel in the fact that long-term cooperation arrangements may bring about the aforementioned "alignment" with the mindset and interests of the financial backer. The sponsor may also, as suggested in the cited article on the Gates Foundation, become a "blind spot" in the media organisation's coverage.

There is, however, another important phenomenon that is further muddying the waters between publishers and platforms. In an article published in Journalism (2017), Efrat Nechushtai describes this process as "infrastructural capture," defined as a situation in which a regulatory institution - in this case the media is no longer able to lastingly operate without the digital resources of the organisations it is

2 As examples, Horvath and Powell highlight funding for schools by Bill and Melinda Gates' and Mark Zuckerberg's foundations. 
supposed to be overseeing (Nechushtai 2017: 10). Specifically, Nechushtai understands this to mean the news media's growing dependence on the products and services of platform corporations such as Google; her article also discusses the tech companies' funding programmes and in particular the instruments created for the media, such as the Subscribe with Google platform.

The dangers of such infrastructural dependence have since come to the attention of politicians. A report for the EU Commission on the question of European media sovereignty notes that while Google's funding of the media, for example, is appreciated for its intelligent and uncomplicated approach, it still "raises real issues" for many companies. When it comes to distribution, advertising, audience measurement (through software such as Google Analytics), research, and development, these companies are increasingly dependent on Google (Klossa 2019: 64).

\subsection{Interim summary: three dimensions of press independence}

Press independence is considered essential to ensure that news media organisations in liberal democracies can fulfil their brief as the "fourth estate". This chapter outlined two different yet related developments that risk upsetting the delicate balance between press and economic interests that has existed in the media industry for many years: the crisis being experienced at traditional newspapers, closely associated with considerable pressure to cut costs, and the rise of platform companies - in particular
Google - as partners, competitors, and patrons of the media.

In our systematic analysis of the potential risks to press independence posed by Google, we distinguish between three levels, set out below, as an aid to understanding the statements quoted in later chapters. As there is currently very little scholarly literature on the ties binding Google and publishers, or on the specific nature of media funding espoused by the data company, the study is based on the findings related to foundation-financed journalism and the concept of "infrastructural capture":

Individual level: This level concerns the independence of individual journalists. Are there attempts or ways to influence them personally? Where might we find potential dependencies, for example the acceptance of privileges addressed in the Press Code?

Editorial level: As set out above, the traditional separation of publisher and newsroom is increasingly crumbling under economic pressure. In the case of foundation financing, it is also apparent that this funding impacts on the subjects and processes of journalism. This level therefore concerns the independence of editors and newsrooms. Do persons or products influence their work and processes?

Economic or publishing level: This level concerns the economic independence of publishers. Are dependencies arising? Is flexibility being restricted? This chapter has used available literature to illustrate how publishers see their freedom to act being eroded by the platforms and suggests the emergence of a potential infrastructural dependency. 


\section{Study design}

\subsection{Research questions}

The objective of this study is to examine the relationship between German news media organisations and the tech corporation Google with regard to the question of press independence. Chapter 2 showed that the digital transformation has sparked considerable change processes at news media companies, affecting both how they are organised, i.e. how journalists' work is created and disseminated, and how they are financed in the light of changing business models. External actors in the form of tech corporations - and in particular Google - have now entered the fray and are directly involved in both these processes.

The available literature on Google's role in the development of journalism, however, is extremely limited and primarily draws on news and essay-based sources. Empirical scientific findings on the technological, financial, and personal ties that link the news media and Google are severely lacking. The present study picks up the thread here, focusing on these ties and the potential dependencies they give rise to. Its aim is to systematically examine Google's role in the organisation and financing of news media organisations and present findings on the potential consequences of these relationships. In specific terms, this objective thus prompts the following research questions:

1. How did Google's media funding initiatives come about?

2. How did German news media organisations benefit from Google's financial support from the Digital News Innovation Fund within the European Digital News Initiative?

3. How did German news media organisations benefit from events, training, and fellowships financed by Google?

4. To what extent do news media organisations and journalists in Germany use Google products as part of their technical infrastructure?

5. What threats do these ties pose to the independence of the news media and journalists - at individual, editorial, and publishing levels?

In responding to these questions, the study draws on a combination of empirical analyses. Employing a multi-method design (see Brosius et al. 2016: 86) involving a standardised survey of news publishers on their use of Google products (see Chapter 3.2), a media funding data analysis for the Digital News Innovation Fund (see Chapter 3.3), and guided interviews with digital journalists and publishing managers in charge of digital issues (see Chapter 3.4), the authors attempt to build up a full picture of the relationship between the German news media and the tech corporation Google. The history and structure of the News Initiative is set out on the basis of literature and online research, as well as an interview with two top Google managers (see Chapter 3.5). The authors of the study identified additional sources in a systematic review of Google publications, blog posts and media reports from various different European countries, and freedom of information requests to the EU Commission. 
Given the current paucity of scholarly investigations into the subject, the present study as a whole is exploratory in nature and aims to make initial inroads into previously uncharted territory. In doing so, it hopes to act as a starting point for further research.

The authors came to this study with a strong history of journalism research. In 2018, they published a series of articles on the Digital News Initiative based on an analysis of data from the first four DNI Fund funding rounds. These articles were published on netzpolitik. org and the website of the European Journalism Observatory (see Fanta 2018; Dachwitz 2018). Also based on this data, media organisations in Austria and Switzerland published analyses for their own countries (see Goldenberg 2018; Fichter 2018).

\subsection{Standardised survey on product relationships}

A key aspect of the ties between Google and the news media is the media industry's dependence on the tech companies' products. This can be seen, on the one hand, at the muchdiscussed level of online "audience flows"; an inability to find news content on Google, Google News, and YouTube would compromise the reach of digital news media. Another factor, though, has received less public attention: the frequent use of Google products at almost every point in the digital journalism value chain. The actual extent of this use in Germany has not to date been examined, and this study attempts to address the issue through a standardised online survey that was sent to German media organisations.

Online research and briefings with journalists identified over 30 Google services that may potentially be in use by the media in Germany, and their scope covers the entirety of a journalist's work process, from research (e. g. Google Maps and Google Search) and communication (Gmail and Google Docs), to security (Google Authenticator, Google Shield, reCaptcha) and hosting (Google Drive and AMP), to publishing (Google Publisher and Google CMS) and monetisation of journalism products (Google Analytics, Google Ads and AdX, Subscribe with Google).

A standardised online survey was developed to obtain reliable information on how many of these products are in use by German news media companies. The authors devised 31 questions to determine whether the listed products and services are used. They also asked whether the surveyed companies had taken on fellows within Google's News Lab programme, a training initiative for journalism students and recent graduates, or whether employees had participated in Google conferences or training. As with the interviews, all of the respondents were assured anonymity.

The invitation to take part in the online survey was sent by email to 173 German media companies. The list of surveyed companies is made up of the 150 online news media organisations with the widest reach according to an analysis by the German Audit Bureau of Circulation (IVW) (IVW 2020). The list was supplemented by the list of media used by the Ger- 
man Federal Chancellery for its press cuttings, known as the "Kanzlermappe" ("chancellor's file") (FragdenStaat.de 2019a). Due to their limited relevance to the subject of the study, sports media, gossip magazines, and blogs not emanating from a media company were removed from the list.

The survey was conducted in March and April 2020, i. e. at the beginning of the coronavirus pandemic in Germany. Citing the crisis, several media companies declined to take part. Following a seven-week fieldwork phase, in which several reminders were sent, $22 \mathrm{com}$ plete replies were received from the media organisations. This equates to a response rate of around 13 percent. The sample includes small and regional press publishers as well as specialist media and large media companies. In part, the respondents also took part in the oral interviews. The results make no claim to be representative, but they do provide a relevant insight into the spread of Google's services. A list of the media organisation contacted, the survey, and the accompanying letter can be found in the study's online appendix (the Google services queried can be found in Table 9).

\subsection{Digital News Innovation Fund data analysis}

A further key element of this study involves an analysis of cash flows from the Digital News Innovation Fund. Google used this funding instrument, part of the Digital News Initiative, to pay out more than 140 million euros to European media organisations, research institutions, individuals, and start-ups. The information Google provides on the DNI Fund, however, is inadequate for the purposes of analysis. While the company published DNI reports for 2017 and 2018, and provides both a brief description of all projects on the News Initiative website as well as detailed information on a number of model projects in blog posts, it does not release specific details, in particular those relating to funding amounts. This information therefore had to be obtained through our own research.

The first step was to compile a database of 645 DNI-funded projects, for which the rudimentary information on the projects published by Google on the News Initiative website served as the basis. This data was obtained from the sub-pages of the News Initiative website with the help of software in March 2018 and January 2020 and then transferred to a database. ${ }^{3}$ Google provides the following information:

- Name: Project name

- Actor: Name of lead applicant

- Country: Country in which the lead applicant is based

- Summary: Brief summary of project idea

- Solution: More detailed description of the solution the project aims to provide to a problem

3 Google itself claims that it funded a total of 662 projects. On the DNI website, however, the company provides information on just 645 projects. Some entries are duplicates; for various reasons, others never came to fruition, despite being approved for funding. 
- Type: Google does not provide any information on specific funding amounts, instead classifying the projects it funds in three categories based on size. "Prototype" projects received up to 50,000 euros. "Medium" projects received between 50,000 and 300,000 euros. "Large" projects received between 300,000 and $1,000,000$ euros.

Following extensive research from April to June 2018 and again from February to March 2020, the resulting data set was supplemented by further data and extra, inductively derived project categories:

- Funding round: The DNI Fund accepted applications in six consecutive rounds. Successful recipients were notified in February and November 2016, in July and December 2017, and in July 2018 and March 2019. Wherever possible, a record was made of which project was funded in which funding round.

- Specific funding amount: The specific funding amount was added wherever this information could be obtained through online research or direct query by email or telephone. This was the case in 295 of 645 projects.

- Recipient type: Recipients of funds were categorised in one of six types based on their organisational and financing mechanisms: commercial media, non-profit me- $\mathrm{dia}^{4}$, publicly funded media ${ }^{5}$, individuals, non-journalism organisations, and universities/research institutions.

- Founding year: Except for individuals, the founding year of the recipient organisation was established.

Project type: Based on the information published by Google on the funded projects, projects were assigned to one of six different types:

> Community: this covers projects that focus on sharing with and involving a community (e. g. community engagement, crowdsourcing, user-generated content).

> Data and automation: this includes projects that develop technical tools that assist in the collection, generation, preparation, and dissemination of information within editorial processes (e.g. robot journalism, data journalism, automated visualisation, automated feeds, automated content management systems).

> Revenue models without advertising: this category covers projects that aim to monetise journalism products without the use of advertising (e. g. paywalls, log-in services).

> Fact-checking: this covers projects that aim to verify facts and build trust.

> Format innovation: this category includes all projects that concern the development of ways to present journalism (e. g. videos, podcasts, virtual reality).

\footnotetext{
4 This refers to media organisations whose owners are not profit-oriented, for example because they are registered charities or cooperatives.

5 This includes both state and public service funded media.
} 
> Advertising: this covers projects that aim to advance monetisation opportunities using advertising (e.g. user tracking, audience management).

In order to reveal patterns in the distribution of DNI funds, the data in Chapter 5 is evaluated using statistical methods.

\section{The transparency problem}

As explained above, missing information and extra categories were initially added to the projects and recipients on the basis of online research. Where precise funding amounts were not publicly accessible, the recipients were contacted by email for this information. German recipients also received a telephone follow-up if no reply was forthcoming.

Despite this extensive groundwork, exact information regarding the funding sums awarded was obtained for just 295 of the 645 projects overall. Some respondents cited business secrecy concerns or the (alleged) imposition by Google of a non-disclosure agreement - although there is no mention of this in the DNI Fund terms and conditions (see Google News Initiative 2018). Other recipients sent no reply at all.

Concrete figures are, however, required to enable a comparative summary; the authors therefore made estimates for those projects for which exact sums could not be obtained. These estimates are based on the available information regarding the funding that the 295 transparent projects received in their respective categories. The estimate for the "large" category was 515,000 euros, for the "medium category" 200,000 euros, and for the "prototype" category 40,000 euros.

These estimates may of course be incorrect in some cases and, depending on the category, out by tens or even hundreds of thousands of euros. Overall, however, they appear to be highly plausible: according to Google, the total funding awarded over the six rounds came to 140.7 million euros, while the study authors, using the estimates set out here, came to an overall sum of 140.4 million euros.

In some cases, our conversations with project managers revealed that the funding amounts cited in third-party sources were incorrect. It may therefore be the case that some projects have been assigned incorrect figures in the database because we relied on publicly accessible sources wherever possible. Our database also inadequately reflects cooperation projects on which the project partners come from different countries. In these cases, we used the country in which the organisation listed by Google as the primary actor is based.

\subsection{Guided interviews with digital jour- nalists and managers}

Another key element of this study is a survey of digital managers at German media organisations. In order to obtain as comprehensive a picture as possible of feelings towards Google, interviews were conducted with people in positions of responsibility at publishers and in newsrooms. In keeping with the exploratory nature of this study, a partially standardised 
qualitative survey was conducted in the form of guided interviews (see Lamnek 2005: 21; Brosius et al. 2016: 107).

The sampling of the respondents was based on the principles of qualitative research, with the aim of obtaining generalised findings from as wide an experience set as possible. Instead of aiming for statistical representativeness, the interviewees were selected such that maximally typical representatives of each sector of the industry could be investigated (see Lamnek 2005: $186 \mathrm{ff}$.). A set of criteria was defined to select respondents in different categories. These criteria include whether the media organisation received funds from Google and its primary focus, where we differentiated between popular media and specialist IT media, as well as between national and regional media. Representatives from broadcasting media, despite it not being a focus of the News Initiative, were also surveyed. In our survey of digital journalists, we also took care to ensure that both permanent employees and freelancers were interviewed (see Table 1).

The majority of respondents were recruited by email. Of a total of 30 managers, chief digital officers (CDOs), and other digital managers from publishing houses that were asked, 14 were willing to be interviewed for the study. Even after several follow-ups (some by telephone), more than half of the publishing managers we asked could not be persuaded to participate. The most common reason given was that they did not want to comment publicly on the subject. There was considerably greater willingness to participate among the digital journalists we asked: 11 of the 15 persons took part in the survey.

\section{Table 1}

Overview of 25 respondents

\begin{tabular}{|l|c|c|c|}
\hline & Managers & Journalists & Total \\
\hline DNI funding & 10 & 5 & 15 \\
No DNI funding & 4 & 6 & 10 \\
\hline Print/online & 11 & 8 & 19 \\
\hline Radio/online & 3 & 3 & 6 \\
\hline Privately funded & 12 & 8 & 20 \\
\hline Publicly funded & 2 & 3 & 5 \\
\hline Popular media organisation & 13 & 7 & 20 \\
\hline Specialist media organisation & 1 & 4 & 5 \\
\hline National & 12 & 7 & 19 \\
\hline Regional & 2 & 4 & 6 \\
\hline
\end{tabular}


To ensure that the digital journalists would feel as free as possible to speak about their work, their independence, and their relationship with Google, they were assured partial anonymity. Nothing in this study would allow them, their employers, or their clients to be personally identified. Potential interviewees from the publishing camp also voiced concerns about speaking publicly on their relationship with Google and the News Initiative. At a relatively early stage of the fieldwork phase, a decision was therefore taken to also partially anonymise the statements provided by publishing managers.

For reasons of transparency, however, a summary of the media organisations whose CDOs, managers, and other leading employees responsible for digital strategies we spoke to is set out below:
- Axel Springer SE
- Badische Zeitung
- Bauer Media Group
- Berliner Verlag
- Der Spiegel
- Deutsche Welle
- Frankfurter Allgemeine Zeitung
- funk (ARD and ZDF content network)
- Golem.de
- Gruner + Jahr
- Krautreporter
- RTL
- taz, die Tageszeitung
- Zeit online

Due to the limited number of digital journalists in Germany, a similar overview for this group of respondents is not disclosed here. A full list of interviewees is held by the Otto Brenner Foundation.

Even though the gender of the interviewees is of negligible importance to the sampling and evaluation of this survey, it should be made clear here, for reasons of full transparency, that the majority of them are male. The preliminary study conducted in 2018 had already shown that the project managers among the DNI Fund recipients were predominantly men. Even after specifically approaching potential female interviewees, we were unable to level the playing field, with the result that just 6 of the 24 participants are women, three members of each group of respondents.

For the survey of digital managers and journalists, two different guides were developed, each containing a common core of identical questions. Their design is based on the research questions addressed in this study. One thematic block concerns the use of Google products and experiences with project funding within the Digital News Initiative, as well as the use of Google training opportunities and events. Respondents were also asked for their general view of Google's role in the media industry and their personal feelings towards the company. All participants were explicitly asked about potential attempts by Google to exert influence. They were also asked to reflect on their own - economic and reporting - independence in the context of a variety of relationships with Google. While digital managers were additionally asked about their organisations' digital strategies, a number of questions for the journalists concerned their experience of reporting 
on Google. Both guidelines can be found in the online appendix to the study.

The interviews were conducted in the period from 10 January to 16 March 2020, either in person or by telephone. With the consent of the interviewees, the conversations were recorded on a smartphone or audio recorder. A service provider was contracted to perform a rough transcription of the interviews, which the authors then corrected.

The interviews were evaluated using the method of qualitative content analysis (see Mayring/Fenzl 2019: 633ff.). In the first step, categories were defined in advance on the basis of the research questions and supplemented by categories inductively derived from the interviews. After this, the authors sifted through all the interviews and assigned individual passages to different categories. In the third step, the individual categories were evaluated by sorting, summarising, and condensing the text excerpts to answer the research questions.

\subsection{Interview with Google managers}

Since our literature and online research left a number of questions on the history and structure of the Digital News Initiative unanswered,
Google was also asked for an interview. On 26 March, a one-hour interview in English was conducted with News Initiative managers using an online video conferencing programme. Participating in the interview were:

Madhav Chinnappa, Director for News Ecosystem Development at Google. The former journalist joined the company in 2010 and, in this role, has built up and is responsible for both the European Digital News Initiative and its global successor program, the Google News Initiative.

Ludovic Blecher, Head of Google News Initiative Innovation Challenges. Blecher is thus responsible for Google's current global media funding programme. Previously, the former journalist managed the DNI fund as part of the European Digital News Initiative and before that, Google's publisher Fund in France.

Ralf Bremer, Press Spokesman for Google Germany, also took part in the discussion. He also answered several questions in writing and authorised the transcribed interview.

The original transcription of the interview is available in the online appendix. 


\section{History and structure of Google's news initiatives}

There is currently very little literature on the relationship between Big Tech and the media. Google's funding programmes for the media, in particular, have to date eluded rigorous scholarly inquiry. This chapter therefore uses publicly accessible sources and an interview with Google managers to outline a historical summary of Google's funding programmes. Prior to that, however, we summarise our knowledge of the grants already issued or presently earmarked for issue, before responding to this study's first research question:

1. How did Google's media funding initiatives come about?

According to Google itself, the company has to date spent at least 210 million euros on media projects. The Digital Publishing Innovation Fund, launched in France in 2013, accounts for 60 million of this total; some 56 million euros went to media organisations, while the remaining four million were spent on administering the fund. Google committed 150 million euros to the Digital News Initiative; according to its own reports, the company paid out some 141 million euros for projects under the auspices of the Digital News Innovation Fund. Further money was spent within the Google News Lab on fellowships, conferences, and research institutions. Since then, the corporation has committed a further 300 million dollars of funding within the global Google News Initiative (GNI) over the years 2019 to 2021.

All in all, it is therefore difficult to gauge exactly how much money the corporation has spent on supporting the media in the last few years. Table 2 shows a summary of the available news media funding programmes - the figures, however, represent only the sums granted directly for the innovation projects submitted by certain media (publishers). A quantitative analysis of Google's overall funding for journalism is available in the form of a report compiled by the Google Transparency Project (GTP), an initiative of the US-based NGO Campaign for Accountability. The information provided by the NGO should be treated with caution, how-

\section{Table 2}

Summary of Google funding programmes for news media

\begin{tabular}{|l|l|l|l|l|l|}
\hline Period & Name & Abbreviation & Region & Total value & $\begin{array}{l}\text { Funding } \\
\text { instrument }\end{array}$ \\
\hline 2013-2015 & - & FINP & France & 60 million euros & $\begin{array}{l}\text { Digital Publishing } \\
\text { Innovation Fund }\end{array}$ \\
2015-2019 & $\begin{array}{l}\text { Digital News } \\
\text { Initiative } \\
\text { 2019-today }\end{array}$ & $\begin{array}{l}\text { Google News } \\
\text { Initiative } \\
\text { *The approx. 263 million euros have been converted from the announced 300 million dollars. Source: own research. }\end{array}$ \\
\hline
\end{tabular}


ever, as it does not issue any public reports on its funding and, according to one press report, was financed by Google's competitor Oracle (Roberts 2016). Nevertheless, the project has made its data, covering a total of 1,157 media projects funded by Google worldwide, publicly available; it includes all publicly known journalism grants provided by Google, among them funding for universities and training programmes. Even given a certain amount of scepticism regarding its motives, the report provides a good idea of the global reach of the corporation's media funding operations. As it says, Google committed a total of between 567 and 569 million dollars of funding within the Google News Initiative and other programmes; precise funding figures were not available for a further 170 projects (Campaign for Accountability 2019: 2).

\subsection{A political backdrop}

In the early 2010s, Google is coming under pressure in Europe. The corporation's online advertising business is growing rapidly, but Google's revenues are squeezing profit margins at Europe's publishers. Many established newspaper firms in Europe hoped to make up for their falling print revenues with ad revenues from the internet - but without success (see Lobigs/Neuberger 2018: 165).

This structural economic shift is not without political consequences. Germany is one of the first countries to see news publishers calling for action. At the Delegates' Assembly organised by the German Newspaper Publishers
Association in May 2009, they demand legal measures to counter the "free exploitation of their web content". They call for the introduction of an ancillary copyright law for news publishers, which sets out fees to be paid for the use of their content (BDZV 2009).

Shortly after, the French copyright collecting society SACD demands a dedicated tax on online advertising revenues (Girardeau 2009a). It aims to hit the "big winners" in the online advertising market. A Google representative counters that this would create a "digital tax hell” (Girardeau 2009b). Nevertheless, the SACD's proposal quickly gathers political support. In January 2010, a commission of the French Ministry of Culture proposes a tax of one to two percent on online advertising revenues (see Zelnik et al. 2010: 5of.). The French President of the time, Nicolas Sarkozy, instructs the Ministry of Finance to examine the proposal (Collet et al. 2010). Sarkozy also instructs the Competition Authority to look into Google's position in the online advertising market. The idea initially comes to nothing, but is later implemented in 2016 as the French "YouTube tax" (Woitier 2017).

In Germany, meanwhile, Chancellor Angela Merkel announces that an ancillary copyright law for news publishers is in the works at the BDZV conference in September 2011 (see Buschow 2012). This law would see even short text extracts from news items protected by copyright, and focus on content aggregator sites such as Google News, which link to news articles with brief teaser texts. According to Chancellor Merkel, these services "in part rely 
on the work of other publishers, but without compensating them," a "problematic" issue (Bundesregierung 2011). The ancillary copyright law would force Google and other aggregator sites to pay millions to news publishers.

France also announces an ancillary copyright law on the initiative of President François Hollande, who succeeds Nicolas Sarkozy in office in May 2012. Google then threatens to exclude French websites from its search results (Pfanner 2012).

In this tense situation, a Belgian case attracts great attention. Since 2006, Google has been engaged in a legal battle there with publishers and copyright collecting societies as to whether publishing brief snippets of text from other publications on Google News constitutes a copyright infringement. The corporation relents in December 2012: according to Le Monde, it agrees to pay damages of five million euros. "The press can beat Google," writes Le Monde (Ternisien 2012).

\section{The Digital Publishing Innovation Fund in France}

A short time later, Google opens a new chapter in its relationship with publishers in France. In the presence of scores of journalists, French President François Hollande signs an agreement with Google CEO Eric Schmidt on 1 February 2013. Under this agreement, Google promises the French press a 60-million-euro fund, the Digital Publishing Innovation Fund, to support the "digital transformation, investment, and innovation" (Schmidt 2013). "France is filled with pride to have reached this agree- ment, [...] the first of its kind in the world," declares Hollande (Élysée 2013).

Months of negotiations had preceded this agreement. The publishers had originally demanded 70 million euros in compensation for "abusively" indexing and linking their content, reports media journalist Frederic Filloux. Google initially hesitated but ultimately decided to hammer out a deal - "instead of perpetuating a latent hostility that could subsequently explode and cost much more," as Filloux puts it (2013).

The new fund, known by its French acronym FINP (Fonds pour l'Innovation Numérique de la Presse) starts operating in September 2013. It is limited to a period of three years and set to pay out 20 million euros a year. How the money is disbursed is decided by the Fund's Board of Directors, made up of representatives from Google and the press, as well as independent experts (FINP 2013). Major recipients include French media such as Les Echos, Le Figaro, the free paper 20 Minutes, and Paris Match. In many cases, the Fund is used to finance key projects at these publishers. One example: according to Google, Le Monde receives money for a new smartphone and tablet service (Verney 2015). Companies received up to 60 percent of the total cost of a project, with the remainder coming out of their own pockets. In total, the Fund paid out 55,985.112 euros to publishers, according to Google (see Appendix A). The manager of the Fund, Ludovic Blecher, himself later moves to Google, where he initially takes responsibility for the new Innovation Fund under the Digital News Initiative, for which the French fund was the blueprint, and later the GNI Innova- 
tion Challenges, Google's present funding programme (see Chapters 4.2 and 4.3).

While Google courts publishers in France, new problems loom elsewhere. In Italy, Prime Minister Enrico Letta proposes a "Google tax" (Reuters 2013), designed to ensure that firms that advertise and sell in Italy have a tax presence in the country. Just a few weeks later, however, the plans are dropped by Matteo Renzi, who replaces Letta following a power struggle in the Italian centre-left camp (Reuters 2014).

In Spain, too, the government reforms copyright laws. From early 2015, a "Google tax" forces news aggregator sites to pay compensation for linked content. In response, Google News closes down in Spain (Sharkov 2014).

In Germany, the ancillary copyright law in force since 2013 is not increasing revenues for publishers. Most of the publishers organised in the VG Media copyright collecting society allow Google to display their content on Google News and in the corporation's search engine free of charge (Spiegel 2014). The ancillary copyright law thus fails in practice because Google threatens to exclude the publishers from its search results and thus limit their reach - for publishers evidently a more serious loss than their lack of compensation.

Adopting such tactics allows Google to avoid paying costly licensing fees, but around the middle of the decade, the corporation again finds itself under considerable outside pressure. In October 2014, Günther Oettinger, at the time the EU's designated Commissioner for Digital Economy and Society, uses an interview to announce an internet copyright tax (Handels- blatt 2014) - a shot across the bows for Google and online corporations. Oettinger's announcement shows that Jean-Claude Juncker's EU Commission, in office from November 2014, is prepared to take regulatory action to rein in the online giants. The Financial Times summarises the situation in an article from early 2015: "Google needs more friends in Europe” (Waters 2015).

In the following years, the struggles surrounding the new EU Copyright Directive grow into a political quarrel between Google and the publishers. The latter, through their European industry bodies, the European Newspaper Publishers' Association and the European Magazine Media Association, push for an EUwide ancillary copyright law. The publishers' strategy of lobbying EU legislators subsists in criticising Google and other technology corporations' alleged excessive political influence, reports a lobby watchdog NGO (Corporate Europe Observatory 2018a). At the end of the day, the publishers are successful: the ancillary copyright law is enshrined as Article 15 of the Directive. While Google continues to resist obligatory payments under ancillary copyright law, the corporation returns to the publishers with a new offer in mid-2020. Google announces a licensing programme to pay publishers for "high-quality content". As part of the programme, the publishers will release some of their content from behind the paywall and make it available through Google News and Discover. The new Google programme initially launches in just three countries: Australia, Brazil, and Germany. The first participating German publishers are Der Spiegel, the Frankfurter All- 
gemeine Zeitung, Die Zeit, and the Rheinische Post (Bender 2020).

Although news publishers and Google are adversaries on the question of copyright, they are allies on other political issues. Data protection is one example of this. When it comes to the ePrivacy Regulation, publishers and the tech corporation are united in lobbying against rules that aim to severely limit web user tracking for marketing purposes (Corporate Europe Observatory 2018b). ${ }^{6}$

\subsection{Google's European funding opera- tions: the Digital News Initiative (DNI)}

Google announces its Digital News Initiative (DNI) in April 2015. Modelled on the French fund, Google promises to provide grants of 150 million euros to Europe's media companies. In addition to the DNI Fund and its grants for journalism projects, the News Initiative comprises two further aspects: free training courses for journalists and dialogue with publishers on Google products. A working group involving selected publishers, the DNI Working Group, is established for the latter.

Well-known media organisation will be involved at its inauguration in 2015, among them from Germany Die Zeit and the Frankfurter Allgemeine Zeitung. Industry bodies such as the International News Media Association and the Global Editors Network are also involved as partners (Verney 2015).
Google does not deny that political pressure had a part to play in the establishment of the DNI. Madhav Chinnappa, Director for News Ecosystem Development at Google, replied to the study authors' question on this matter:

I think that the pressure and the things that were happening were a bit of a wake-up call to Google to go: "Wait a second, we seem to be very misunderstood here. Because we think we're doing all kinds of good stuff and then there's people saying these things. What's happening here?" And that's when we used this kind of trusted group, focus group with the founders of DNI to say: "Hold on a second, we feel that we're doing quite a lot, but we seem to be misunderstood. Can you help us do the things that you think we should be doing? Help us shape this in a better way.

Madhav Chinnappa 2020, interview in Appendix B

\section{The Digital News Innovation Fund (DNI Fund)}

The Digital News Innovation Fund is at the heart of Google's News Initiative in Europe. European media, research institutions, and news-related organisations and individuals can apply in one of three funding categories by submitting a brief project description and budget: for up to 50,000 euros ("prototype"), up to 300,000 euros ("medium"), and up to $1,000,000$ euros (“large”). Funding is provided for technical innovations, but not for content. According to

6 Sustained lobbying is part of the reason why the EU nations have to date been unable to adopt a decision regarding the regulation proposed in 2017 - thus preventing, with the involvement of the publishers, stricter rules on advertising tracking by Google (see Dachwitz/Fanta 2018). 
Google's terms and conditions, the company will pay up to 100 percent of project costs on "prototype" projects and up to 70 percent on "medium" projects. The terms and conditions do not stipulate an upper funding limit for "large" projects (Google News Initiative 2018: 2).

An 11-member advisory board, the DNI Fund Council, decides on the award of funds for projects valued at over 50,000 euros. This board includes three Google representatives, two scientists, and six representatives from the publishing industry. Staff at the DNI Fund directly award funds to prototype projects with a financial value of 50,000 euros or less. The chairman of the DNI Council is the Austrian Veit Dengler, who was CEO of the Swiss NZZ-Mediengruppe until 2017 before joining the Executive Board of Bauer Media Group in Hamburg. In Miriam Meckel, publisher of WirtschaftsWoche, the jury also includes a leading German publisher (Google News Initiative 2016).

According to Google, the DNI Fund received a total of 5,154 applications in the years 2015 to 2018 (see Appendix A). Over six rounds of funding, the corporation pledged money to 662 projects in 30 countries (see Chapter 5 for a detailed analysis of cash flows). The DNI announced the sixth and final round of funding in March 2019 (Blecher 2019a). Overall, Google has thus provided funding worth a total of $140,689,000$ euros. In addition, the Fund has so far organised two major DNI conferences in Paris and Amsterdam, as well as numerous local and regional events.

Funding recipients say that the money from the Digital News Innovation Fund is made avail- able quickly and unbureaucratically, with few conditions attached. As related by them to the authors of this study in 2018, there has been no interference from Google in the projects (Dachwitz 2018). They add that there is no requirement to present specific project outcomes or program code. The project leads only need to provide the Digital News Initiative with rough information on the progress of their innovation projects and the attainment of predefined milestones. There are also external audits, which are set out in the terms and conditions of the DNI Fund (Google News Initiative 2018: 4).

Despite the fact that project descriptions are published on the Digital News Initiative website, how much money is spent, and where, remains unclear. Google does not publish exact funding figures for the majority of the projects it supports, and many recipients prefer not to discuss this issue.

Some grants from the DNI Fund have been controversial. In its final round of funding in March 2019, the Fund awarded "prototype" funding of up to 50,000 euros to the progovernment Hungarian media company New Wave Media Group for a project relating to the Origo news site. This website is considered a government mouthpiece and frequently attacks migrants and the investor George Soros, who has been a favoured target of anti-Semitic campaigns in Hungary. The New York Times publishes a look at Origo under the headline "The Website That Shows How a Free Press Can Die" (Kingsley/Novak 2018). Following a report on the MediaPowerMonitor blog (2019), information about the Origo grant disappeared from 
the DNI website. Google later sends a statement to the NiemanLab blog at Harvard University saying that the Fund had decided not to go ahead with the grant (Schmidt 2019).

\subsection{Worldwide funding: the Google News Initiative (GNI)}

In March 2018, Google announces plans to transform the European initiative into a global project on conclusion of the DNI funding rounds - the Google News Initiative (see Table 2 for a summary). The corporation promises to commit 300 million dollars to the initiative. In a statement, Google stresses the economic significance of its relationship with publishers:

Platforms like [Google] Search and YouTube depend on a healthy ecosystem of publishers producing great digital content. That's why it's so important to us that we help you drive sustainable revenue and businesses. Last year, we paid \$12.5 billion to partners and we drove 10 billion clicks a month to publishers' websites for free.

(Schindler 2018).

The initiative, from now on known as the GNI, itself promulgates three objectives: to elevate and strengthen quality journalism, to empower news organisations through technical innovation, and to evolve business models to drive "sustainable growth" (ibid.). The GNI brings together Google's previously separate initiatives. Grants are awarded to publishers, but also to conferences, research institutions, and young journalists. Thanks to its generous award of funds, Google is creating a biotope of interlinked funding systems that will benefit an entire generation of budding media professionals.

The sub-programme to provide grants for innovation projects at publishers is significantly scaled down compared to its predecessor in Europe: where the DNI Fund paid out 140 million euros, Google manager Ludovic Blecher announces a pot worth 30 million dollars, i.e. around 27 million euros, for the new GNI Innovation Challenges, to be disbursed in the years 2019 to 2021 (Blecher 2019b). Here, again, media organisations can apply in funding rounds, each of which is dedicated to one world region and one topic. As with the European DNI, the jury will be made up of Google representatives and external experts from the news industry in the respective region (see ibid.).

According to its own reports, Google has to date funded 108 projects in Asia-Pacific, Latin America, North America, the Middle East, Turkey, and Africa (Google News Initiative 2020b). As it expands the geographical reach of its project funding, the Google News Initiative is becoming established in parts of the world where press freedom is restricted. The significance of this can be seen from funding commitments of GNI Innovation Challenges to pro-government media organisations in Rwanda and the United Arab Emirates. These two countries rank 131st (United Arab Emirates) and 155th (Rwanda) of 180 countries in the World Press Freedom Index compiled by Reporters Without Borders (Reporters Without Borders 2020). 


\section{Fellowships, training, conferences}

The GNI Fellowships, financed by Google, are now a fixed part of the GNI, although they were previously funded as News Lab Fellowships from 2013, prior to the establishment of the GNI. The programme gives journalism students and recent graduates the chance to spend several weeks of paid work in newsrooms. It operates in the USA, Australia, South Korea, and 13 European countries, and, according to Google, produced some 300 alumni in its first five years alone (Drake 2018). The 2020 programme promises future "Fellows" an eight-week sojourn in a newsroom and pay of up to 5,000 euros. Participating German media organisations this year are the Frankfurter Allgemeine Zeitung, the Tagesspiegel, Zeit Online, Der Spiegel, Stern Digital, Rheinische Post, and the Funke Mediengruppe (Journalism Fellowships in Europe 2020).

Google also organises and finances online courses and training. Considering only the funds awarded to the Society of Professional Journalists and its journalism training programme, the corporation says it trains around 4,000 journalists in the use of its products over one or two-day courses (Whitaker 2019).

The corporation also enjoys hosting press and publishing staff. Google has been organising the annual Newsgeist Conference in the USA and Europe since 2013; in the USA, it co-sponsors the event with the prestigious Knight Foundation. For Newsgeist, Google invites a selected group of people from the news industry to attend workshops and informal discussions; the conference is held in a different city each year. The guest list at the event held in Lisbon in June 2019 includes figures such as Der Spiegel's online editor Barbara Hans, Wikipedia founder Jimmy Wales, and other well-known industry names (Fanta 2018).

Together with the European Journalism Centre, Google has since 2014 also been organising an event for a wider audience, the News Impact Summit, a conference that in December 2019 was held at Google's headquarters in Munich (News Impact 2019). It invites journalists from across Europe to engage in discussion on diversity and inclusion in the newsroom; admission is free.

The Google News Initiative is also the main sponsor of the International Journalism Festival in Perugia, one of Europe's biggest meet-ups for the media industry. The GNI also sponsors the Global Investigative Journalism Conference, which in 2019 took place in Hamburg and, according to the event organisers, was attended by 1,700 journalists from 130 countries (GIJC 2019).

In addition to providing funding to publishers, young journalists, and conferences, Google also makes major contributions to support academic research on the media. As one example, GNI finances the Journalism Al project run by the Polis think tank at the London School of Economics, which addresses artificial intelligence in journalism (Beckett 2019). Polis received 175,000 euros from Google for research and workshops, the London School of Economics said in response to an enquiry by the authors of the present study (see email in online appendix). 
One major recipient of Google money not connected to the DNI is the Reuters Institute for the Study of Journalism at the University of Oxford. Between August 2015 and August 2020 , the institute received a total of 8.47 million pounds for its Digital News Report, an annual study on the state of the media industry (Reuters Institute 2018). In February 2020, Google and the Reuters Institute announced a funding extension for a further three years (Reuters Institute 2020a). ${ }^{7}$

With the ending of the DNI Fund and the launch of the Google News Initiative, the focus of funding for publishers changed. While projects previously supported with DNI funding frequently produced in-house software solutions, many of the GNI programmes are clearly linked to Google products. One example is GNI YouTube Innovation Funding, under which the initiative provided 25 million dollars to support partner organisations in developing novel news formats for the corporation's own video-sharing platform. The focus, then, has shifted from allowing publishers to carry out their own innovation projects to content partnerships. The media may have a free hand in editorial matters, but it is also clear that content is to be produced for Google's video platform. In Germany, recipients of this funding are Der Spiegel and Stern.de (YouTube official blog 2018).

The situation is similar for subscriptions. GNI announced that its Subscriptions Lab exists to help publishers in Europe improve their online subscription strategies. And the corpora- tion has just the right product for this purpose, Subscribe with Google, which publishers can use to let users take out subscriptions through their Google accounts (Gingras 2020).

In the US and the UK, GNI also finances the establishment of new news media. Together with publishing company McClatchy, Google launched three local news laboratories in "news deserts," i.e. small and medium-size communities that lack a local news service. The first was due to launch in Youngstown, a former industrial city in Ohio with a weak local news infrastructure. McClatchy would be the owner and operator of the local news site; Google would assist with its own "experts” (Forman 2019).

A similar approach is being taken by the British publisher Archant in the city of Peterborough with its Peterborough Matters news site. "Our partnership with the Google News Initiative enables us to meld the best of our editorial minds with Google's expertise in best product practices," says a reporter for the new service in a Google blog post (Baker 2020).

\subsection{Philanthropy and self-interest}

As set out above, Google's funding operations through the French Fund and the DNI have probably also made it Europe's biggest patron of journalism. A key impetus behind its initial forays were the appeals from many media organisations for stricter (financial) regulation of the corporation and the associated political pressure.

7 The Institute also received between 50,000 and 200,000 pounds from Facebook for the 2018/2019 academic year (Reuters Institute 2020b). 
The underlying purpose of the aforementioned initiatives, however, remains generally unclear: is the money intended as a philanthropic gesture? The corporation never uses the word "donation," and has not established a non-profit foundation for its grants. The sums are disbursed from corporation accounts. "The Digital News Initiative is also a PR instrument for Google to win over the European publishing industry," says Veit Dengler, media manager and Chair of the DNI Fund (Fanta 2018). Journalism researcher Emily Bell - co-author of the Platforms and Publishers multi-year study and a leading voice in discourse on the role of tech corporations in journalism - writes in Columbia Journalism Review that the funding comes directly from the corporation's marketing budget (Bell 2019). This was disputed by Google managers when asked by the present study's authors. Those interviewed, however, did not say which part of the company is actually responsible (see Appendix A).

When pressed, Google remained tight-lipped. On a scale between philanthropy and pure self-interest, the initiatives are "somewhere in the middle," says Madhav Chinnappa, Google's Director for News Ecosystem Development, in an interview with the study's authors in March 2020. He adds that the company pursues both non-material and business objectives:

From a values perspective, we share a lot of the same values as the news industry about how an informed citizen makes for a better society. But there also are business reasons behind this. Google is an ecosystem company. The way that it makes money is through the ecosystems it operates in. So it thrives when the ecosystem thrives.

Madhav Chinnappa 2020, interview in Appendix B

One way of seeing Google's journalism funding is as a form of "disruptive philanthropy," as described by the authors in Chapter 2.4 . As Horvath and Powell argue (Horvath/Powell 2016: 5), a distinctive feature of this kind of philanthropy is its ability to shape how people view social problems and champion ways to address them through media, publicity, and by "changing the conversation". In view of Google's wide-ranging involvement, this can certainly be said to be the case for not only media organisations but also discourse-shaping institutions such as conferences, institutes of journalism, and training programmes. Other features cited by Horvath and Powell (ibid.) are disruptive philanthropy's belief in the "redemptive virtues of competition" and its "look at new models of funding public goods". Both these features can easily be discerned in Google's stated objectives in its news initiatives of financing innovation and the development of new business models.

There is some speculation among publishers that Google's News Initiative (see Chapter 5 ) is motivated by the company's desire to further embed its own products within the publishing industry. Google denies this, with Chinnappa, in a statement given to netzpolitik.org in 2018, averring that the DNI Fund is explicitly not linked to Google products and aims only 


\section{Digital ecosystems}

The term "ecosystem" is one used in biology, but ecosystems are commonly also referred to in discussions of the internet. The online encyclopaedia Wikipedia defines the term as follows: "A digital ecosystem is a distributed, adaptive, open socio-technical system with properties of self-organisation, scalability and sustainability inspired from natural ecosystems. Digital ecosystem models are informed by knowledge of natural ecosystems, especially for aspects related to competition and collaboration among diverse entities" (Wikipedia 2020). The term, as also understood by the study's authors and some of their interviewees, thus encompasses both the idea of a technical infrastructure and a sociotechnical system. Google manager Chinnappa, for example, talks about news ecosystems on the web, which cover both the technical infrastructure of news pages and their content. Viewed this way, single web pages are not self-contained but instead thrive on the sharing of technical resources and ideas, the use of similar keywords and taxonomies, and mutual citations and links. The term "ecosystem" is also used in a similar way by people in the publishing industry.

to promote innovation in the digital news ecosystem in Europe (Fanta 2018). Two years later, his colleague Ludovic Blecher tells the authors of the present study that the formal decisionmaking structure of the DNI Fund requires a strict separation of the Fund and Google's business interests (Ludovic Blecher 2020, interview in Appendix B). The terms and conditions do indeed state that funds are to be awarded by the advisory board, the DNI Council, but all final decisions must be approved by Google, which also renews or extends the periods of office for the Council members (Google News Initiative 2018: 3). Moreover, the decision-making teams for the GNI Innovation Challenges, the shrunken successor to the DNI Fund, are now only briefly convened. Google itself is also the sole decision-maker on other funding programmes within the global Google News Initiative, for example the targeted funding pot for YouTube formats at news publishers. Whatever else may be the case, then, it is clear that the GNI is more explicitly designed to establish Google products than its predecessors (see Chapter 4.3).

\subsection{Interim summary: funding pro- grammes under political auspices}

We can thus now answer the first research question regarding how Google's news funding initiatives came about. Where the data giant initially adopted a strategy of direct competition with the established news publishers, for example in the online advertising arena, it adjusted this strategy in the light of growing political pressure and began launching its 
media funding programmes. The company took the first step to institutionalising its grants in France, where, acting under pressure from the French government, it established its first fund for the newspaper industry in 2013 (see Chapter 4.1).

The programme was evidently a great success for Google, so much so that it was expanded to cover all of Europe in 2015 and afforded greater structural and financial leeway. Alongside the high-profile Digital News Innovation Fund, the Digital News Initiative (DNI) was based on two further pillars: free training for journalists and a regular roundtable event to discuss the development and design of new Google products with representatives from major European media organisations.

Google then announced its next step in 2018: the News Initiative would go global from 2019 and unite all the funding instruments for the media landscape under one roof. To add to the naming confusion, it has since been called the Google News Initiative or GNI. The global programme is better funded than ever before, but the initiative's focus has shifted: Google now only provides 30 million euros, a significantly reduced sum, to fund independent innovation projects. Furthermore, the corporation is now increasingly placing its own products at the centre of its funding operations, for example Subscribe with Google within the Subscriptions Lab or its own video-sharing platform within GNI YouTube Innovation Funding.

The managers of Google's news initiatives deny that the funds come from the corporation's marketing budget, stating that the programmes are located somewhere in the middle between philanthropy and self-interest. They add that this underscores Google's responsibility towards the news ecosystem. 


\section{Media funding with the Digital News Innovation Fund}

Of the programmes addressed in Chapter 4, the Digital News Innovation Fund, which paid out a good 140 million euros to recipients in Europe over six rounds from 2016 to 2019, will be examined in more detail below.

This chapter will then answer the second and fifth research questions of this study:

2. How did German news media organisations benefit from Google's financial support from the Digital News Innovation Fund within the European Digital News Initiative?

5. What threats do these ties pose to the independence of the news media and journalists - at individual, editorial, and publishing levels?

In the following, a quantitative analysis of the DNI Fund is first used to shed light on how Google's money was distributed to the European media industry and to examine identifiable priorities in the funding process (Chapter 5.1). Which countries benefited, and to what extent? Who were the recipients of grants? What kind of innovation was funded? Who received money in Germany?

This is followed by a qualitative analysis of the DNI Fund based on interviews with publishing managers and digital journalists from Germany: Why did German media organisations apply for Google funding, and how was it organised (Chapter 5.2)? Did funding impact on press independence (Chapter 5.3 ) ${ }^{8}$

\subsection{Results of the DNI Fund data analysis}

Before going into detail on the results of the data analysis, mention must be made of the adverse circumstances that accompanied the attempt to shed light on this information. Google itself shrouds its DNI Fund in a particular kind of opaque transparency. The company does publish rudimentary information about the projects it funds on the DNI website, but, crucially, not in a clear list. Instead, this data is presented on separate sub-pages for each project, which must each also be loaded separately. In blog posts on the DNI website and in the published interim reports for 2017 and

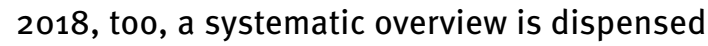
with in favour of an informal look at selected projects. As stated in Chapter 4.2, Google refers to funding categories, not specific funding amounts.

More detailed information on the methodology can be found in Chapter 3.3. It is worth reiterating here that, despite extensive research, specific funding sums could not be ascertained on over 295 projects, a problem exacerbated by the fact that Google is not alone in being tight-lipped about revealing precise figures. Only very few funding recipients are themselves

8 Omitted from detailed examination here is the funding of scholarly institutions such as the Reuters Institute for the Study of Journalism at the University of Oxford, addressed in Chapter 4.3 above, who were not recipients of DNI Fund grants. Also not discussed are cooperation arrangements between media companies and Google outside the scope of the News Initiative, such as Zeit Online and the "Deutschland spricht" project or the Handelsblatt and Google's

“Zukunftswerkstatt” (Zeit Online 2018, Handelsblatt Media Group 2019). 
happy to divulge the sums they received from Google, and even when contacted in writing or by telephone, many were reluctant to reveal this information. Concrete figures are, however, required for a comparison of cash flows. In the present case, as set out in Chapter 3.3, we will be using estimates. A summary of all projects can be found in the online appendix.

\section{Where does the money go? \\ Germany benefits the most}

Over the three years in which the DNI operated, funds were awarded to projects emanating from all 27 EU member states, as well as Norway, Switzerland, and the UK. Project numbers and funding amounts vary considerably from country to country. Of the 645 projects, just one each in Malta and Cyprus were funded. In other small nations such as Estonia and Luxembourg, this figure rises to two, in Croatia three, and five each in Bulgaria, Latvia, and Slovenia.

With 92 funded projects, Germany is the country with the most recipients, followed by the UK with 76 projects, France with 75, Spain with 48, and Italy with 44. As shown in Table 3, however, a higher number of projects is not always an indication of higher funding sums, but must be considered in relation to the different categories of funding. British recipients, for example, outnumbered their French colleagues by just one project, but with a large share of "prototypes" overall received far lower total funding.
For the top ten recipient countries, analysis of the funding amounts produces the following picture: Germany heads the table with around 21.5 million euros and 15 percent of the total funding. ${ }^{9}$ France received 20.1 million and thus 14 percent of all DNI grants. According to Google, the UK was the recipient of almost 15 million euros (10.6 percent of total funds). In fourth place was Spain with a good 12 million euros (8.6 percent). Italy took fifth with 11.5 million euros (8 percent); sixth was Portugal with almost eight million euros ( 5.6 percent). Poland is next with 6.6 million euros ( 4.7 percent), followed by the Netherlands and Belgium in eighth and ninth place respectively, receiving 5.5 and 5.3 million euros (nearly 4 percent). With funding of 3.8 million euros, Norway takes 1oth place (2.7 percent).

In total, then, these 10 countries received more than three quarters of all the money available in the Digital News Innovation Fund. Even though Google does not explicitly say so, the data shows that the DNI is very much focussed on western European nations. Poland is the only eastern European country to make it into the top ten of recipient nations.

This, however, does not yet provide us with a way to explain the reasons for this imbalance. Since it was not Google itself but rather a jury comprising a majority of external representatives that awarded funding for medium and large projects, a deliberate attempt to influ-

9 In the German version of this study, this chapter works with estimated numbers for each country since Google had not released official numbers. Three days after the publication of the German study, Google published the final report on the Digital News Initiative including total numbers for each country (Digital News Innovation Fund Impact Report, Google 2020: https://newsinitiative.withgoogle.com/dnifund/documents/44/DNIFund_Impact_Report.pdf, retrieved on 04 November 2020). For the English version we worked with these official numbers, which is why some numbers in this chapter and especially Table 3 look slightly different from the German version. 


\section{Table 3}

DNI funding by country

\begin{tabular}{|c|c|c|c|c|c|c|}
\hline Country & $\begin{array}{l}\text { Total number of } \\
\text { projects }\end{array}$ & $\begin{array}{c}\text { Number of } \\
\text { “large" projects } \\
\text { funded }\end{array}$ & $\begin{array}{l}\text { Number of } \\
\text { "medium" } \\
\text { projects funded }\end{array}$ & $\begin{array}{l}\text { Number of } \\
\text { "prototype" } \\
\text { projects funded }\end{array}$ & $\begin{array}{c}\text { Total } \\
\text { (in euros) }\end{array}$ & $\begin{array}{l}\text { Percentage } \\
\text { of total DNI } \\
\text { funding }\end{array}$ \\
\hline Germany & 92 & 28 & 25 & 39 & $21,500,000$ & $15.3 \%$ \\
\hline France & 75 & 24 & 32 & 19 & $20,100,000$ & $14.3 \%$ \\
\hline United Kingdom & 76 & 19 & 17 & 40 & $14,900,000$ & $10.6 \%$ \\
\hline Spain & 48 & 16 & 16 & 16 & $12,100,000$ & $8.6 \%$ \\
\hline Italy & 44 & 17 & 9 & 18 & $11,500,000$ & $8.2 \%$ \\
\hline Portugal & 31 & 12 & 5 & 14 & $7,800,000$ & $5.6 \%$ \\
\hline Poland & 33 & 6 & 18 & 9 & $6,600,000$ & $4.7 \%$ \\
\hline Netherlands & 29 & 6 & 8 & 15 & $5,500,000$ & $3.9 \%$ \\
\hline Belgium & 18 & 7 & 8 & 3 & $5,300,000$ & $3.8 \%$ \\
\hline Norway & 20 & 2 & 8 & 10 & $3,800,000$ & $2.7 \%$ \\
\hline Switzerland & 16 & 5 & 4 & 7 & $3,400,000$ & $2.4 \%$ \\
\hline Austria & 15 & 2 & 7 & 6 & $3,000,000$ & $2.1 \%$ \\
\hline Finland & 19 & 3 & 6 & 10 & $2,900,000$ & $2.1 \%$ \\
\hline Sweden & 14 & 4 & 5 & 5 & $2,800,000$ & $2.0 \%$ \\
\hline Hungary & 16 & 3 & 5 & 8 & $2,600,000$ & $1.9 \%$ \\
\hline Denmark & 15 & 3 & 6 & 6 & $2,500,000$ & $1.8 \%$ \\
\hline Greece & 11 & 3 & 2 & 6 & $2,300,000$ & $1.6 \%$ \\
\hline Ireland & 8 & 4 & 0 & 4 & $1,900,000$ & $1.4 \%$ \\
\hline Romania & 16 & 2 & 2 & 12 & $1,800,000$ & $1.3 \%$ \\
\hline Slovakia & 5 & 2 & 1 & 2 & $1,500,000$ & $1.1 \%$ \\
\hline Czech Republic & 12 & 0 & 6 & 6 & $1,500,000$ & $1.1 \%$ \\
\hline Lithuania & 6 & 2 & 1 & 3 & 910,000 & $0.6 \%$ \\
\hline Croatia & 3 & 1 & 1 & 1 & 850,000 & $0.6 \%$ \\
\hline Slovenia & 7 & 1 & 1 & 5 & 843,000 & $0.6 \%$ \\
\hline Luxembourg & 2 & 1 & 1 & 0 & 770,000 & $0.5 \%$ \\
\hline Bulgaria & 5 & 0 & 2 & 3 & 503,000 & $0.4 \%$ \\
\hline Cyprus & 1 & 1 & 0 & 0 & 450,000 & $0.3 \%$ \\
\hline Estonia & 2 & 1 & 0 & 1 & 441,000 & $0.3 \%$ \\
\hline Latvia & 5 & 0 & 0 & 5 & 250,000 & $0.2 \%$ \\
\hline Malta & 1 & 0 & 1 & 0 & 150,000 & $0.1 \%$ \\
\hline Total & 645 & 175 & 197 & 273 & $140,467,000$ & $100 \%$ \\
\hline
\end{tabular}


ence outcomes on the corporation's part can be ruled out. Other factors, such as the number and quality of the applications received, are likely to have carried greater weight.

It is only at first glance that funding totals appear to correlate with population numbers: Germany, Europe's most populous nation, received the most money, followed by France and the UK, the continent's second and third largest countries. In terms of "per capita funding," however, media organisations in eastern and south-eastern European countries received far less grant money. This becomes particularly clear if we consider not only the number of projects per country but also the funding categories and the sums associated with them: in eastern and south-eastern European countries, the majority of funded projects are in the medium or prototype categories. Romania, for example, is the sixth most populous country in the European Union, but ranks 19th in terms of DNI funding totals. Bulgaria has the 15th biggest population in the EU but comes 26th in the DNI ranking. By contrast, Portugal and nonEU country Norway, both in the DNI's top ten recipients, fare considerably better than might be expected on the basis of their population numbers.

A more compelling way of understanding the data is to compare the biggest European newspaper markets. According to the German Newspaper Publishers Association (BDZV), Germany leads with 16.8 million papers sold every day (BDZV 2019). Some way behind are the UK (9.8 million) and France (6.2 million). Italy has the fourth largest newspaper market in Europe
(3.2 million), followed by the Netherlands in fifth (3.0 million), Spain in sixth (2.6 million), and Poland in seventh place (2.2 million). Sweden, Austria, and Switzerland occupy 8th to 10th place (1.8 million each). Seven out of ten of these are also in the top ten for den DNI; only Austria, Sweden and Switzerland drop off this list in favour of Belgium, Portugal and Norway.

\section{Who receives funding? Commercial and established media dominate}

A glance at the funding recipients in Table 4 reveals a clear picture: with 379 funded projects, commercial media account for considerably more than half of all recipients (59 percent). As this group has received a particularly high number of large project funding sums (75 percent of all projects in the "large" category), the percentage of the total funding provided to "traditional" commercial media organisations is actually even higher: with an estimated 102 million euros, some 73 percent of the DNI Fund went to these media organisations. Recipients in this category include leading European newspapers and media companies such as Le Monde, El Pais, Corriere della Sera, the Financial Times, and the Neue Zürcher Zeitung. German recipients include Der Spiegel, Zeit Online, the Frankfurter Allgemeine Zeitung, the Handelsblatt, and publishers Gruner + Jahr (see also Chapter 5.1.4). Broadcasting media are also occasionally to be found among the funding recipients.

These organisations are followed by funding recipients who do not actually work in journalism, with a funding total of around 21.5 mil- 
lion euros (15 percent). This group includes service providers for the media industry, think tanks, agencies, foundations, and industry associations, and received a particularly large number of grants for prototype projects: of 145 projects (22 percent of the total), 94 are in the smallest funding category.

In third place and a long way behind, with 42 projects and an estimated figure of just under 6.5 million euros (5 percent), are non-profit media. In Germany, this group includes Krautreporter, Correctiv, and the cooperative-owned daily newspaper taz.
Funding levels for publicly funded media are similarly low, with an estimated 5.7 million euros paid out to 16 funded projects (4 percent of total funding). This money went to organisations such as the state-owned French press agency AFP and news agencies in Slovenia, the Czech Republic, and Cyprus, as well as public service broadcasters in Italy, Ireland, the Netherlands, France, and Belgium. Within this group, Deutsche Welle is the only funding recipient from Germany.

In addition, 17 projects at universities and research institutions were awarded DNI funding

\section{Table 4}

DNI funding by recipient category

\begin{tabular}{|c|c|c|c|c|c|}
\hline Recipient & $\begin{array}{l}\text { Total number } \\
\text { of projects }\end{array}$ & $\begin{array}{c}\text { Number of } \\
\text { "large" } \\
\text { projects funded }\end{array}$ & $\begin{array}{c}\text { Number of } \\
\text { "medium" } \\
\text { projects funded }\end{array}$ & $\begin{array}{c}\text { Number of } \\
\text { “prototype" } \\
\text { projects funded }\end{array}$ & $\begin{array}{c}\text { Estimated } \\
\text { total* } \\
\text { (in euros) }\end{array}$ \\
\hline Commercial media & $\begin{array}{c}381 \\
(59 \%)\end{array}$ & $\begin{array}{c}132 \\
(75 \%)\end{array}$ & $\begin{array}{c}154 \\
(78 \%)\end{array}$ & $\begin{array}{c}95 \\
(35 \%)\end{array}$ & $\begin{array}{l}102,580,000 \\
\quad(73 \%)\end{array}$ \\
\hline $\begin{array}{l}\text { Non-journalism } \\
\text { organisations }\end{array}$ & $\begin{array}{c}145 \\
(22 \%)\end{array}$ & $\begin{array}{c}24 \\
(14 \%)\end{array}$ & $\begin{array}{c}27 \\
(14 \%)\end{array}$ & $\begin{array}{c}94 \\
(34 \%)\end{array}$ & $\begin{array}{l}21,520,000 \\
(15 \%)\end{array}$ \\
\hline Non-profit media & $\begin{array}{c}42 \\
(7 \%)\end{array}$ & $\begin{array}{c}6 \\
(3 \%)\end{array}$ & $\begin{array}{c}13 \\
(7 \%)\end{array}$ & $\begin{array}{c}23 \\
(8 \%)\end{array}$ & $\begin{array}{c}6,661,000 \\
(5 \%)\end{array}$ \\
\hline $\begin{array}{l}\text { Publicly funded } \\
\text { media }\end{array}$ & $\begin{array}{c}16 \\
(2.5 \%)\end{array}$ & $\begin{array}{c}10 \\
(6 \%)\end{array}$ & $\begin{array}{c}2 \\
(1 \%)\end{array}$ & $\begin{array}{c}4 \\
(1.5 \%)\end{array}$ & $\begin{array}{l}5,710,000 \\
\quad(4 \%)\end{array}$ \\
\hline $\begin{array}{l}\text { Universities and } \\
\text { research centres }\end{array}$ & $\begin{array}{c}17 \\
(2.5 \%)\end{array}$ & $\begin{array}{c}3 \\
(2 \%)\end{array}$ & $\begin{array}{c}1 \\
(0.5 \%)\end{array}$ & $\begin{array}{c}13 \\
(5 \%)\end{array}$ & $\begin{array}{l}2,265,000 \\
\quad(2 \%)\end{array}$ \\
\hline Individuals & $\begin{array}{c}41 \\
(6 \%)\end{array}$ & 0 & 0 & $\begin{array}{c}41 \\
(15 \%)\end{array}$ & $\begin{array}{c}1,640,000 \\
(1 \%)\end{array}$ \\
\hline Total & $\begin{array}{c}645^{\star \star} \\
(100 \%)\end{array}$ & $\begin{array}{c}175 \\
(100 \%)\end{array}$ & $\begin{array}{c}197 \\
(100 \%)\end{array}$ & $\begin{array}{c}273^{\star \star} \\
(100 \%)\end{array}$ & $\begin{array}{c}140,445,000 * * \\
(100 \%)\end{array}$ \\
\hline
\end{tabular}

*Estimates - large: 515,000; medium: 200,000; prototype: 40,000 $\star \star$ The combined totals for the stated grants differ from the totals given here by three projects or 120,000 euros. This is because three "prototype" projects could not be clearly classified. Note: deviations from $100 \%$ due to rounding. Source: own research. 
(3 percent). As this group received considerably more small funding sums than the publicly funded media, the funding total is estimated here at around 2.3 million euros, or two percent of total funding. In Germany, funds went to the Hamburg Media School ("large" category), Bauhaus University, Weimar ("prototype" category), and Martin Luther University of Halle-Wittenberg ("prototype" category).

A further 41 individuals (6 percent) received funding, each with a "prototype" project. Three minor projects could not be classified, as no further information about them could be obtained.

A glance at the funding recipients' founding years shows that the majority are not start-ups but rather established media organisations. The median founding year of those organisations that received funding is 1996. If we discount individuals, it can be seen that 324 of the 604 organisations have existed for over 20 years; 54 percent of them were therefore founded before the year 2000 . These "established" recipients also received the lion's share of grants over 300,000 euros: their 123 projects in the "large" category account for some 70 percent of all projects of this size.

By comparison, recipient organisations founded since 2010 account for 186 projects and a total of 31 percent. These young organisations, however, received just 31 grants in the "large" category, i.e. a total of 18 percent of large projects. Within this group, the proportion of prototype funds is also particularly high: 58 percent of the projects submitted by recipient organisations founded since 2010 received a maximum 50,000 euros of funding (107 projects).

The data analysis thus shows a clear imbalance in DNI funding at the level of the funding recipients. The majority of Google's money went not just to western European countries, but indeed to commercial and established media organisations.

\section{What is funded? Data and automation projects in the ascendant}

The DNI Fund described itself as promoting innovation in journalism. The majority of funds were paid out to projects carried out in the field of "data and automation" (see Table 5; for information on categorisation, see Chapter 3.3). It is estimated that nearly 54 million euros were distributed to 251 projects of this type, i. e. 38 percent of the funding total. One example is the German company Trint, which received 300,000 euros to improve its software enabling the automated transcription of audio files (speech-to-text transcription).

The second largest group is made up of projects that involve the testing and development of new technical formats, e.g. in the audio field or using virtual reality. Around 31.5 million euros are estimated to have been paid to 141 projects of this type, equating to 22 percent of total funding. The Belgian industry organisation Lapresse. be, for example, received 400,000 euros to develop a new module for delivering audio content through its smartphone app.

Eighty-eight funded projects addressed the question of ways to generate revenue not involving advertising. Most of them trialled new 
models to see how news content can be paid for by readers. Examples include membership schemes or new iterations of paywalls. Estimates suggest that $\mathbf{2 2 . 5}$ million euros were spent funding these projects, i.e. 16 percent of total funding. As an example, the Slovakian newspaper Denník $N$ received 333,000 euros to develop analysis software that alerts publishers when subscribers' interactions with the site suggest that they are about to cancel their subscriptions.

Sixty-eight projects addressed the fields of community, crowdsourcing, and user-gen- erated content, receiving close to 14.5 million euros or 10 percent of total funding. The Italian GEDI News Network, for example, which publishes the country's high-circulation daily paper La Repubblica, was awarded money to develop a new platform for subscribers to interact. The exact sum granted in this case is not known, but lies somewhere between 300,000 and one million euros.

An estimate of around eight million euros was granted to 33 projects that deal with advertising revenues (6 percent of total funding). An example is the Styria Media Group,

\section{Table 5}

DNI funding by project type

\begin{tabular}{|c|c|c|c|c|c|}
\hline Topic areas & $\begin{array}{l}\text { Total number } \\
\text { of projects }\end{array}$ & $\begin{array}{c}\text { Number of } \\
\text { "large" } \\
\text { projects funded }\end{array}$ & $\begin{array}{c}\text { Number of } \\
\text { "medium" } \\
\text { projects funded }\end{array}$ & $\begin{array}{c}\text { Number of } \\
\text { "prototype" } \\
\text { projects funded }\end{array}$ & $\begin{array}{c}\text { Estimated } \\
\text { total* } \\
\text { (in euros) }\end{array}$ \\
\hline Data and automation & $\begin{array}{c}251 \\
(39 \%)\end{array}$ & $\begin{array}{c}67 \\
(38 \%)\end{array}$ & $\begin{array}{c}75 \\
(38 \%)\end{array}$ & $\begin{array}{c}109 \\
(40 \%)\end{array}$ & $\begin{array}{l}53,865,000 \\
\quad(38 \%)\end{array}$ \\
\hline Format innovation & $\begin{array}{c}141 \\
(22 \%)\end{array}$ & $\begin{array}{c}41 \\
(23 \%)\end{array}$ & $\begin{array}{c}40 \\
(20 \%)\end{array}$ & $\begin{array}{c}60 \\
(22 \%)\end{array}$ & $\begin{array}{c}31,515,000 \\
(22 \%)\end{array}$ \\
\hline $\begin{array}{l}\text { Revenue models (wi- } \\
\text { thout advertising) }\end{array}$ & $\begin{array}{c}88 \\
(14 \%)\end{array}$ & $\begin{array}{c}29 \\
(17 \%)\end{array}$ & $\begin{array}{c}32 \\
(16 \%)\end{array}$ & $\begin{array}{c}27 \\
(10 \%)\end{array}$ & $\begin{array}{l}22,415,000 \\
(16 \%)\end{array}$ \\
\hline Community & $\begin{array}{c}68 \\
(11 \%)\end{array}$ & $\begin{array}{c}18 \\
(10 \%)\end{array}$ & $\begin{array}{c}21 \\
(11 \%)\end{array}$ & $\begin{array}{c}29 \\
(11 \%)\end{array}$ & $\begin{array}{l}14,630,000 \\
(10 \%)\end{array}$ \\
\hline Advertising & $\begin{array}{c}33 \\
(5 \%)\end{array}$ & $\begin{array}{c}9 \\
(5 \%)\end{array}$ & $\begin{array}{c}15 \\
(8 \%)\end{array}$ & $\begin{array}{c}9 \\
(3 \%)\end{array}$ & $\begin{array}{l}7,995,000 \\
(6 \%)\end{array}$ \\
\hline Fact-checking & $\begin{array}{c}48 \\
(7 \%)\end{array}$ & $\begin{array}{c}7 \\
(4 \%)\end{array}$ & $\begin{array}{c}11 \\
(6 \%)\end{array}$ & $\begin{array}{c}30 \\
(11 \%)\end{array}$ & $\begin{array}{l}7,005,000 \\
(5 \%)\end{array}$ \\
\hline Other & $\begin{array}{c}16 \\
(2 \%)\end{array}$ & $\begin{array}{c}4 \\
(2 \%)\end{array}$ & $\begin{array}{c}3 \\
(2 \%)\end{array}$ & $\begin{array}{c}9 \\
(3 \%)\end{array}$ & $\begin{array}{c}3,020,000 \\
(2 \%)\end{array}$ \\
\hline Total & $\begin{array}{c}645 \\
(100 \%)\end{array}$ & $\begin{array}{c}175 \\
(100 \%)\end{array}$ & $\begin{array}{c}197 \\
(100 \%)\end{array}$ & $\begin{array}{c}273 \\
(100 \%)\end{array}$ & $\begin{array}{c}140,445,000 \\
(100 \%)\end{array}$ \\
\hline \multicolumn{6}{|c|}{$\begin{array}{l}\text { *Estimates - large: } 515,000 \text {; medium: } 200,000 \text {; prototype: } 40,000 \\
\text { Note: deviations from } 100 \% \text { due to rounding. Source: own research }\end{array}$} \\
\hline
\end{tabular}


Austria's third largest media company, awarded 50,000 euros for a project entitled "Content to Commerce" that aims to replace banner adverts with personality tests.

Google paid out some seven million euros (5 percent) for 48 fact-checking projects. The British investigative journalism website Bellingcat received 90,000 euros to develop an archive in which social media content from crisishit regions is curated, verified, and analysed.

Sixteen projects, funded to the tune of around three million euros, could not be classified in any of the categories.

\section{Country analysis: who benefits in Germany}

In absolute terms, Germany is the biggest recipient of money from Google's Digital News Innovation Fund. According to Google, recipients of funding there were granted almost 21.5 million euros from the DNI Fund in the years 2016 to 2019 (Deutsche Presseagentur 2019).

At 92, Germany is also the country with the most number of projects to receive funding.${ }^{10} \mathrm{As}$ shown in Table 6, just under half of the projects funded by Google were at commercial media organisations, which very frequently received grants of over 300,000 euros. In total, commercial media organisations received 68 percent of the large grants in Germany, and thus the lion's share of the money provided by Google.

Non-journalism companies such as the Eden Spiekermann agency or the Steady monetisation platform formed the second largest group of recipients, with 26 projects. At over 50 percent, the proportion of smaller prototype grants of up to 50,000 euros is particularly high here. Individuals in Germany received eight project grants from the DNI Fund, all of them in the "prototype" category.

Projects at six non-profit media organisations in Germany were funded: three prototypes, two medium projects, and one large project. Deutsche Welle was the only publicly funded media organisation in Germany to receive project funding, albeit four times. Three universities also received funds, with one, the Hamburg Media School, being granted more than 300,000 euros.

\section{Table 6}

DNI projects in Germany by recipient category

\begin{tabular}{|c|c|c|c|c|c|c|}
\hline Total projects & $\begin{array}{c}\text { Commercial } \\
\text { media }\end{array}$ & $\begin{array}{c}\text { Non-profit } \\
\text { media }\end{array}$ & $\begin{array}{c}\text { Publicly } \\
\text { funded media }\end{array}$ & Individuals & $\begin{array}{c}\text { Non-journalism } \\
\text { organisations }\end{array}$ & Universities \\
\hline 92 & 45 & 6 & 4 & 8 & 26 & 3 \\
\hline
\end{tabular}

10 According to the dpa report, Google itself states that 93 projects were supported in Germany. For more information on the differences between the data used in this study and Google's figures, see Chapter 3.3. 
By and large, the list of recipients in Germany reads like a Who's Who of the German publishing industry. Table 7 shows the $28 \mathrm{Ger}$ man projects in the "large" funding category that received between 300,000 and one million euros from Google. They include Spiegel Online, given almost 700,000 euros for the "Read the Game" project that describes itself as using data analysis and artificial intelligence to improve football coverage. This was in addition to 850,000 euros to develop a voice infrastructure to facilitate the production, publication, and monetisation of audio content. Funke Mediengruppe received 500,000 euros for a video distribution network called "Unicorn" and three other grants of unknown value. WirtschaftsWoche was also given several grants and received 650,000 euros alone to develop a virtual reality club for subscribers (a summary of all funded projects can be found in the online appendix).

As can be seen in Table 7, regional media also benefit from Google's DNI Fund, albeit to a much lesser extent overall. The Berlin Tagesspiegel, for example, received 550,000 euros to develop its newsletter for the city's separate boroughs, Tagesspiegel Leute. The Rheinische Post was given 300,000 euros to develop a trend recognition system to analyse data from millions of online news sources and evaluate trending issues. There are only two further regional media organisations among the 28 projects funded in the "large" category, the Mannheim regional portal Headline24 (680,000 euros for a project to develop automated journalism) and the Schwäbischer Verlag $(371,000$ euros for an automated recommendation system). Of the
25 grants for German projects in the "medium" category, three went to regional publishers: the Neue Osnabrücker Zeitung (294,000 euros for the "Project North Star"), the Schleswig-Holsteinischer Zeitungsverlag (294,000 euros for the "Ambient News" project), and again the Berlin Tagesspiegel (unknown amount for the "Causa" discussion portal).

of the already scarcely represented nonprofit media, only Correctiv received a grant in the "large" category $(500,000$ euros for a community project). In the "medium" category, it is joined by the daily newspaper taz (110,000 euros for the "taz zahl ich" monetisation programme), RiffReporter (unknown amount between 50,000 and 300,000 euros for the "PolyPublisher" project), and Krautreporter (60,000 euros for a reader loyalty project).

Media start-ups are also few and far between in the "large" and "medium" funding categories: they include the aforementioned projects at Correctiv, Krautreporter, RiffReporter, and Headline24, as well as a project at Perspective Daily (105,000 euros for the "Healthy News Diet Assistant" project).

The scale and scope of DNI funding, however, also varies widely among the commercial media. While many recipients received one-off funding, others were awarded grants for several projects. Leading the pack in Germany is Deutsche Welle with four projects on which it is listed as the project lead. The business news publications Handelsblatt and WirtschaftsWoche, both of which are part of DvH Medien $\mathrm{GmbH}$, each received three grants, as did the Frankfurter Allgemeine Zeitung. 


\section{Table 7}

All DNI grants over 300,000 euros in Germany

\begin{tabular}{|c|c|c|c|c|}
\hline Recipient name & Project name & Funding in euros & Recipient category & Topic area \\
\hline $\begin{array}{l}\text { Correctiv - Recherchen } \\
\text { für die Gesellschaft } \\
\text { gGmbH }\end{array}$ & $\begin{array}{l}\text { Virtual Newsroom/ } \\
\text { Crowd Newsroom }\end{array}$ & 500,000 & $\begin{array}{l}\text { Non-profit media } \\
\text { organisation }\end{array}$ & Community \\
\hline Datenfreunde GmbH & xMinutes & $?$ & $\begin{array}{l}\text { Non-journalism } \\
\text { organisation }\end{array}$ & Data/automation \\
\hline Deutsche Welle & news.bridge & 437,500 & $\begin{array}{l}\text { Publicly funded media } \\
\text { organisation }\end{array}$ & Data/automation \\
\hline Deutsche Welle & $\begin{array}{l}\text { Digger - deepfake } \\
\text { detection }\end{array}$ & $?$ & $\begin{array}{c}\text { Publicly funded media } \\
\text { organisation }\end{array}$ & Fact-checking \\
\hline $\begin{array}{l}\text { dpa Deutsche Presse- } \\
\text { Agentur GmbH }\end{array}$ & $\begin{array}{l}\text { C-POP - story driven } \\
\text { reader revenue }\end{array}$ & $?$ & $\begin{array}{c}\text { Commercial media } \\
\text { organisation }\end{array}$ & $\begin{array}{c}\text { Monetisation } \\
\text { (without advertising) }\end{array}$ \\
\hline DuMont Mediengruppe & ReadersClub & 475,000 & $\begin{array}{c}\text { Commercial media } \\
\text { organisation }\end{array}$ & $\begin{array}{c}\text { Monetisation } \\
\text { (without advertising) }\end{array}$ \\
\hline $\begin{array}{l}\text { DuMont Mediengruppe } \\
\text { (DuMont Net) }\end{array}$ & RightHere & $?$ & $\begin{array}{c}\text { Commercial media } \\
\text { organisation }\end{array}$ & Community \\
\hline $\begin{array}{l}\text { Frankfurter Allgemeine } \\
\text { Zeitung GmbH }\end{array}$ & FAZ 9 & 500,000 & $\begin{array}{c}\text { Commercial media } \\
\text { organisation }\end{array}$ & Data/automation \\
\hline $\begin{array}{l}\text { Funke Mediengruppe } \\
\text { (Funke Digital TV } \\
\text { Guide) }\end{array}$ & Unicorn project & 500,000 & $\begin{array}{c}\text { Commercial media } \\
\text { organisation }\end{array}$ & Data/automation \\
\hline $\begin{array}{l}\text { G+J Digital } \\
\text { Products GmbH }\end{array}$ & $\begin{array}{l}\text { Future News (Content } \\
\text { Curation Engine) }\end{array}$ & $?$ & $\begin{array}{l}\text { Commercial media } \\
\text { organisation }\end{array}$ & Data/automation \\
\hline $\begin{array}{l}\text { Greenhouse } \\
\text { Innovation Lab }\end{array}$ & Storycast & $?$ & $\begin{array}{l}\text { Commercial media } \\
\text { organisation }\end{array}$ & Data/automation \\
\hline $\begin{array}{l}\text { Handelsblatt Media } \\
\text { Group GmbH \& Co. (KG, } \\
\text { DvH Medien GmbH) }\end{array}$ & $\begin{array}{l}\text { Text to Speech } \\
\text { Synthesis }\end{array}$ & $?$ & $\begin{array}{c}\text { Commercial media } \\
\text { organisation }\end{array}$ & Format innovation \\
\hline $\begin{array}{l}\text { Handelsblatt Media } \\
\text { Group GmbH \& Co. (KG, } \\
\text { DvH Medien GmbH) }\end{array}$ & $\begin{array}{l}\text { Business News } \\
\text { Platform }\end{array}$ & $?$ & $\begin{array}{c}\text { Commercial media } \\
\text { organisation }\end{array}$ & Data/automation \\
\hline $\begin{array}{l}\text { Headline24 GmbH \& } \\
\text { Co. KG }\end{array}$ & $\begin{array}{l}\text { Human Robo } \\
\text { Journalism (HRJ) }\end{array}$ & 680,000 & $\begin{array}{c}\text { Commercial media } \\
\text { organisation }\end{array}$ & Data/automation \\
\hline $\begin{array}{l}\text { HMS Hamburg Media } \\
\text { School GmbH }\end{array}$ & Urban Storytelling Lab & $?$ & University & Format innovation \\
\hline $\begin{array}{l}\text { Ippen Digital GmbH \& } \\
\text { Co. KG }\end{array}$ & $\begin{array}{l}\text { The Master Graph - } \\
\text { combining realtime } \\
\text { data from audience, } \\
\text { content and advertising }\end{array}$ & $?$ & $\begin{array}{l}\text { Non-journalism } \\
\text { organisation }\end{array}$ & Data/automation \\
\hline iRights.Lab & $\begin{array}{c}\text { The Content Blockchain } \\
\text { Project }\end{array}$ & $?$ & $\begin{array}{l}\text { Non-journalism } \\
\text { organisation }\end{array}$ & $\begin{array}{c}\text { Monetisation } \\
\text { (without advertising) }\end{array}$ \\
\hline
\end{tabular}




\begin{tabular}{|c|c|c|c|c|}
\hline $\begin{array}{l}\text { Presse-Druck- und } \\
\text { Verlags-GmbH }\end{array}$ & Ask Me & 491,000 & $\begin{array}{l}\text { Commercial media } \\
\text { organisation }\end{array}$ & Community \\
\hline RP Digital GmbH & $\begin{array}{l}\text { Trend Recognition Mo- } \\
\text { dule for the Listening } \\
\text { Center }\end{array}$ & 300,000 & $\begin{array}{l}\text { Commercial media } \\
\text { organisation }\end{array}$ & Data/automation \\
\hline $\begin{array}{l}\text { Schwäbischer Verlag } \\
\text { GmbH \& Co. KG }\end{array}$ & $\begin{array}{l}\text { Movement Profile Ba- } \\
\text { sed Recommendation } \\
\text { Engine for Hyperlocal } \\
\text { News and Service Infor- } \\
\text { mation }\end{array}$ & 371,000 & $\begin{array}{c}\text { Commercial media } \\
\text { organisation }\end{array}$ & Data/automation \\
\hline $\begin{array}{l}\text { Der Spiegel } \\
\text { (Spiegel Online) }\end{array}$ & $\begin{array}{c}\text { Read the Game - } \\
\text { New Digital Sport } \\
\text { Journalism based on } \\
\text { Innovative Performance } \\
\text { Analysis }\end{array}$ & 689,116 & $\begin{array}{l}\text { Commercial media } \\
\text { organisation }\end{array}$ & Data/automation \\
\hline $\begin{array}{l}\text { Der Spiegel } \\
\text { (Spiegel Online) }\end{array}$ & $\begin{array}{l}\text { VAMP: Voice and Audio } \\
\text { Monetization Platform }\end{array}$ & $?$ & $\begin{array}{l}\text { Commercial media } \\
\text { organisation }\end{array}$ & Format innovation \\
\hline textOmatic & 3DNA & $?$ & $\begin{array}{l}\text { Non-journalism } \\
\text { organisation }\end{array}$ & Data/automation \\
\hline $\begin{array}{l}\text { Verlag Der Tages- } \\
\text { spiegel GmbH }\end{array}$ & Tagesspiegel Leute & 550,000 & $\begin{array}{l}\text { Commercial media } \\
\text { organisation }\end{array}$ & $\begin{array}{c}\text { Monetisation } \\
\text { (without advertising) }\end{array}$ \\
\hline $\begin{array}{l}\text { Westdeutsche Verlags- } \\
\text { und Werbegesellschaft } \\
\text { (Funke Mediengruppe) }\end{array}$ & $\begin{array}{l}\text { Robot-Assisted User- } \\
\text { Generated-Content \& } \\
\text { Content Sponsoring }\end{array}$ & $?$ & $\begin{array}{c}\text { Commercial media } \\
\text { organisation }\end{array}$ & Community \\
\hline WirtschaftsWoche, Ada & Vocally Yours & $?$ & $\begin{array}{l}\text { Commercial media } \\
\text { organisation }\end{array}$ & Format innovation \\
\hline WirtschaftsWoche & $\begin{array}{c}\text { WiWo Immersive News } \\
\text { Lounge }\end{array}$ & 650,000 & $\begin{array}{l}\text { Commercial media } \\
\text { organisation }\end{array}$ & Format innovation \\
\hline ypsilon.io & Steady (Ypsilon) & 350,000 & $\begin{array}{l}\text { Non-journalism } \\
\text { organisation }\end{array}$ & $\begin{array}{c}\text { Monetisation } \\
\text { (without advertising) }\end{array}$ \\
\hline \multicolumn{5}{|c|}{ Note: $?=$ No information. Source: own research. } \\
\hline
\end{tabular}

Due to the lack of transparency regarding specific funding amounts, however, it is not easy to set out a comparative summary of the largest German recipients. As Table 8 shows, Der Spiegel is the only one of the 10 biggest DNI recipients to disclose figures for its two projects. Even when pressed, neither Handelsblatt nor Gruner + Jahr would reveal any funding figures. The summary of the biggest recipients in Table 8 therefore uses the minimum and maxi- mum possible funding amounts. Exact figures are provided where known.

It is not just the lack of transparency regarding the specific amounts of funding received that make this comparison difficult; unclear ownership structures in the German media industry further muddy the picture.

As an example, the Handelsblatt, WirtschaftsWoche, and Tagesspiegel, three of the largest recipients of DNI funding, are all part of 
DvH Medien GmbH. Zeit Online, which won DNI grants for two "prototype" projects (and an unknown amount outside the DNI Fund for the project "Deutschland spricht"), is also part of Dieter von Holtzbrinck's publishing empire. In total, DvH Medien GmbH companies received grants worth between 1.675 and 5.75 million euros from the DNI Fund. Here again, the lack of transparency on the part of publishers prevents us from providing specific figures, but on the basis of the estimates, a sum of around three million euros may be assumed (see Chapter 3.3 for details of the estimation method).

\section{Table 8}

The 10 biggest German recipients of grants from Google's DNI Fund

\begin{tabular}{|c|c|c|c|c|c|c|}
\hline Recipient & $\begin{array}{l}\text { “Large" } \\
\text { projects }\end{array}$ & $\begin{array}{l}\text { “Medium” } \\
\text { projects }\end{array}$ & $\begin{array}{c}\text { "Prototype" } \\
\text { projects }\end{array}$ & $\begin{array}{l}\text { Minimum total } \\
\text { funding (euros) }\end{array}$ & $\begin{array}{l}\text { Maximum total } \\
\text { funding (euros) }\end{array}$ & $\begin{array}{l}\text { Exact funding } \\
\text { (if known, } \\
\text { in euros) }\end{array}$ \\
\hline $\begin{array}{l}\text { Wirtschafts- } \\
\text { Woche }\end{array}$ & 2 & 1 & 0 & 650,000 & $2,300,000$ & $\begin{array}{c}650,000 \\
? \\
?\end{array}$ \\
\hline Deutsche Welle & 2 & 0 & 2 & 650,000 & $2,100,000$ & $\begin{array}{c}437,500 \\
? \\
50,000 \\
25,000\end{array}$ \\
\hline Handelsblatt & 2 & 0 & 1 & 625,000 & $2,050,000$ & $\begin{array}{l}? \\
? \\
?\end{array}$ \\
\hline Spiegel Online & 2 & 0 & 0 & 600,000 & $2,000,000$ & $\begin{array}{l}850,000 \\
689,116\end{array}$ \\
\hline $\begin{array}{l}\text { DuMont } \\
\text { Mediengruppe }\end{array}$ & 2 & 0 & 0 & 600,000 & $2,000,000$ & $\begin{array}{c}475,000 \\
?\end{array}$ \\
\hline $\begin{array}{l}\text { Frankfurter } \\
\text { Allgemeine } \\
\text { Zeitung }\end{array}$ & 1 & 2 & 0 & 400,000 & $1,600,000$ & $\begin{array}{c}500,000 \\
? \\
?\end{array}$ \\
\hline Tagesspiegel & 1 & 1 & 0 & 350,000 & $1,300,000$ & $\begin{array}{c}550,000 \\
?\end{array}$ \\
\hline Gruner + Jahr & 1 & 1 & 0 & 350,000 & $1,300,000$ & $\begin{array}{l}? \\
?\end{array}$ \\
\hline $\begin{array}{l}\text { Funke Medien- } \\
\text { gruppe }\end{array}$ & 1 & 1 & 0 & 350,000 & $1,300,000$ & $\begin{array}{c}500,000 \\
?\end{array}$ \\
\hline dpa & 1 & 1 & 0 & 350,000 & $1,300,000$ & $\begin{array}{c}? \\
165,000\end{array}$ \\
\hline
\end{tabular}


There are also two recipients of DNI funding, each for a single project, that are part of Funke Mediengruppe, the Westdeutsche Verlags- und Werbegesellschaft ("large" category) and the Berliner Wochenblatt Verlag ("medium" category). The group thus received funding of between 700,000 and 2.6 million euros. Like DvH, Funke does not publish full figures; total funding is therefore estimated at around 1.5 million euros.

At Gruner + Jahr, there is at least one project in the "large" category, the Greenhouse Innovation Lab, operated by the Bertelsmann subsidiary together with affiliated company RTL. The total funding awarded to Gruner + Jahr is therefore between 650,000 and 2.3 million euros. The media company does not publish exact figures for any of its projects; total funding is therefore estimated at some $\mathbf{1 . 2}$ million euros. It also owns 25 percent of Der Spiegel, which with 1.5 million euros is itself one of the biggest recipients of DNI grants.

The Deutsche Pressagentur (dpa), which received a minimum of 350,000 and a maximum of 1.3 million euros, is in turn jointly owned by several German media companies.

\subsection{How DNI projects work in practice}

At present, little is known about how projects funded by Google are coordinated at German media companies or about how the project leads feel with regard to them. Before exam- ining the potential threat to impartiality posed by these project grants in Chapter 5.3, we would therefore first like to look at what the digital managers and journalists we interviewed have to say about the organisational context of the projects.

Of 14 interviewed publishing managers, 10 work at media companies that have received project funding from Google's Digital News Innovation Fund $\left[\mathrm{P}_{1}, \mathrm{P}_{2}, \mathrm{P}_{3}, \mathrm{P}_{5}, \mathrm{P}_{7}, \mathrm{P}_{10}, \mathrm{P}_{11}\right.$, $\left.\mathrm{P}_{12}, \mathrm{P}_{13}, \mathrm{P}_{14}\right]^{11}$

\section{Motivation and assessment}

Most publishing managers cite a lack of financial flexibility to undertake innovation projects in their day-to-day business as their motivation for submitting project proposals to the DNI Fund $\left[\mathrm{P}_{2}, \mathrm{P}_{3}, \mathrm{P}_{5}, \mathrm{P}_{7}, \mathrm{P}_{10}, \mathrm{P}_{11}, \mathrm{P}_{12}, \mathrm{P}_{13}\right]$. A particularly sharp opinion is voiced by the head of a regional publisher, who only recently assumed their role and now offers a harsh assessment of their predecessors' approach to digital issues, whose attitude they outline as follows:

Thank god we found someone like Google to give us money so we can finally do something with the internet and digitisation. It was like saying, let's just see what happens. But that lacked any focus on what actually needed to be done in terms of business strategy, and it didn't say anything about how well it would be executed.

[P14]

11 Here and in the following chapters, the interviewees are identified with a "P" for "publishing manager" or a "J" for "journalist". 
The words of a manager at a respected, widely circulated national media organisation are somewhat less dramatic but still unmistakable:

Whether it's now Facebook with its support for local journalism or YouTube with video formats - there are always options like these. And they'll always be attractive because, at the end of the day, publishers can do a little bit more than would be possible on their own. [P10]

Most of the interviewees accordingly state that without a grant from the DNI Fund, they would not have been able to carry out their submitted tech projects at all. The digital manager of a major newspaper (itself a major DNI Fund recipient in Germany) is the only exception, stating that experimenting "with artificial intelligence and similar technologies" does not actually require funding from Google or other tech companies.

The situation is very different for managers of smaller media companies:

Well, we wouldn't have done it otherwise, because we simply can't afford it.

We're not Der Spiegel or Springer or Holtzbrinck or any of the others where there's still money. Until recently, our publisher wasn't known for spending money on innovation. So we said, hey, it's an opportunity. Here's someone handing out money, and we'd like to make use of it. Just to try out something new.
Representatives from larger publishers, however, also stress the importance of DNI funding for their innovation projects. As an example, the manager of a large national media organisation [P2] says that they would have had to look for other sponsors if DNI funding had not existed. Their project would theoretically have been possible in that case, but would have to have been put back.

In this context, the representative of a large publisher talks about an internal change in strategy. Where they initially experimented freely, they later only submitted projects to Google that were already on the publisher's agenda:

The first project wouldn't have come about without the funding. It was a high-tech project that we wouldn't have had the resources for. [...] However, we still had to invest considerable sums ourselves. That's why we decided to focus more on projects that we consider so essential that we would have done them even without Google's support. [P11]

The manager of a smaller media organisation says that their publication could never have afforded to undertake a project that was not an essential strategic necessity:

We don't have the means to just do something for the hell of it. Sometimes I think that the DNI was in part about funding experiments at large media companies, which usually ended up being shelved. I don't mean that to sound like criticism: it's really important, and great things can come out of it. But we're simply not in the 
situation where we can devote time and manpower to an experiment that doesn't ultimately help us.

Free experimentation or targeted funding for strategic projects - Google's grants are hugely important for innovation projects at German publishers. One interviewee, familiar with the DNI Fund decision-making process, reinforces this feeling in comments about the big picture of DNI project funding:

There really were some truly interesting innovation projects. But there were also many iterations of what l'd call 'catch-up projects,' where things were or should have been moving along, but maybe there wasn't enough money or the owners were stuck in a short-term mindset, and then the DNI money made it happen. In my view, we've frequently seen the industry playing catch-up, starting with paywalls or revenue from event business, for example. These are things that a well-run company should actually have done or intend to do. [...] And this, I think, made it easier for innovators at the companies to get going with their projects.

Hardly any of the interviewees expressed reservations about working together with Google. An exception is the manager of a small media organisation, who reports having misgivings about being funded by Google, allayed following a lengthy internal discussion process:

When it came to it, we said, 'well, we can either die a dignified death or we can get on with our project'. And of course it was great that it worked out. We didn't get any negative reactions from the community. Perhaps because we worked on the principle of transparency. $\left[\mathrm{P}_{3}\right]$

This manager also stresses that the benefits of DNI Fund grants go beyond the actual project itself: the media organisation was able to use some of the funds to hire a new employee, who was later taken on permanently in a different role at the company.

Two interviewees, neither of whom had applied for a DNI Fund grant, actually stated that they would consider Google funding for their media companies in the future. In this respect, one broadcasting manager talks about a clear internal change of strategy, occasioned not only by an internal change of personnel, but also by positive reports from competitors regarding DNI funding:

We've moved away from saying 'we won't do anything with Google'. After all, many of our competitors have worked with Google. And, as far as we can tell, in a relatively productive way, without Google setting any clear expectations. [P9]

The Chief Digital Officer (CDO) of a large regional newspaper [ $\mathrm{P}_{4}$ ], who - due to being in competition with Google in the small ads market does takes a fundamentally sceptical view of media funding by the tech corporation, cites a lack of internal capacity as the reason why their company did not apply for a grant. Restructuring processes meant that resources were not 
available for either organisational integration of a DNI project or an internal political discussion as to whether such funding would even be desirable. This could change, however, they say, but for this CDO, that would be conditional upon the supported projected generating benefits for the entire industry, not just for one publisher. It would therefore be best if such a project were to be carried out jointly by several publishers.

The positive opinion of Google's overall initiative shared by publishing managers does not, however, mean that every project was necessarily considered a success. Several interviewees do state that their DNI-funded projects are still active today $\left[\mathrm{P}_{1}, \mathrm{P}_{2}, \mathrm{P}_{3}, \mathrm{P}_{10}\right]$, but others report that some projects have been aborted [ $\left.\mathrm{P}_{5}, \mathrm{P}_{11}, \mathrm{P}_{14}\right]$.

The failure of a project is attributed to a range of factors, but never to the media organisation's cooperation with Google. One digital manager, for example, mentions an experimental project that was too big to be adopted into regular use $\left[\mathrm{P}_{11}\right]$. Another publishing manager $\left[\mathrm{P}_{5}\right]$ relates the story of a project that failed entirely, involving the loss of an existing, inhouse machine learning algorithm that was at the very heart of the project, together with all of the training data. The data was stored in a Google Cloud and the project lead forgot to renew their subscription: "Just about everything went wrong there." They add that this did not cause any problems with Google because the error was explained and they could transparently show that the project had actually been completed by this point in time. Google also showed itself as accommodating because the project was merely in the "prototype" category. The media organisation later received another grant for a new project.

Almost none of the interviewees criticise Google's handling of the project grants; on the contrary, the majority say they are highly satisfied. They describe its style as unbureaucratic and unobtrusive $\left[\mathrm{P}_{3}, \mathrm{P}_{5}, \mathrm{P}_{7}, \mathrm{P}_{12}\right]$. There were regular queries relating to the attainment of predefined milestones and an external audit of accounts, but otherwise no interference from Google.

Overall, then, almost all of the DNI recipients have a positive opinion of the funding programme. Just two interviewees [P12, $\left.\mathrm{P}_{14}\right]$ say that they would not accept Google money (again) in the future. This, however, has less to do with the News Initiative itself than with the company's internal structure, explains the manager of a national media organisation, pointing to issues with the project-centric nature of the grants [P12]: "It involves greater integration and management effort, which we're not really set up for." Interviewee P14, who did not become the manager of their publishing company until after the award a DNI Fund grant, is the only one to express fundamental concerns about the News Initiative:

From today's vantage point, I would never accept money from Google, because it would immediately cause a conflict of interest. We're happy to use their technologies, but I don't think we'd allow ourselves to be funded by them. In any case, we don't have this situation 
at the moment because we keep these different interests apart.

[P14]

\section{Organisation and role of the newsroom}

As stated above, the separation of the editor and publisher roles in the theoretical and historical development of journalism is a key element in guaranteeing journalists' independence from their financial backers. All of the interviewees whose media organisations received DNI funds were therefore asked separately about the role of the newsroom on their DNI projects. The resulting interviews paint a very uneven picture.

Four of the interviewed digital managers say that traditional newsrooms were either not given a leading role, not significantly involved, or not involved at all in the DNI projects $\mathrm{IP}_{3}$, $\mathrm{P}_{5}, \mathrm{P}_{11}, \mathrm{P}_{12}$. Especially at many larger media organisations, the DNI projects were devised and carried out within specialist product development and innovation departments, or in IT. Two interviewees, however, both of whom work at large German media companies, do also name editorial development teams as the project leads $\left[\mathrm{P}_{2}, \mathrm{P}_{10}\right]$. Such teams act as a kind of interface at a publisher, with people from product development, IT, the newsroom, and other departments working together on new developments. The head of a regional publisher also reports a mixed project team that brought together people from both the publishing company and the newsroom [P14].

One innovation manager explains that the editors who would later work with the development team were involved in coordinating the project, but that the project itself was mostly run by the technical department [P7]. A similar sentiment was expressed by the digital manager of a large national newspaper. With all due respect for the separation of publisher and editor roles, feedback from the latter must be incorporated in the development of innovation projects:

The editors are involved. There's always a consensus: from the idea for the project and the question of whether we want to have Google on board, to moulding it into its final form - which itself resulted in some very specific functions and finally the layout of the functions. The way we work here, everything is very well integrated. None of our projects, whether or not they're financed with Google money, are run in such a way that, say, the editors are taken by surprise because the publisher has changed something in an app. We're not structured that way, and that's a good thing, too.

Newsrooms appear to enjoy greater involvement at smaller media organisations or those with a tech slant [J5, J7]. One journalist, who works at a media organisation that has received funding, puts it like this:

The idea came from the editorial team. Not from me, from others. The question was, what's something really good we could do to get lots of money out of Google? As I remember, it turned out not to be one of those huge projects that the big publishers in Germany were undertaking. [...] The newsroom was involved to the extent 
that a colleague from the editorial team handled all the communication with Google and, I believe, then submitted the project.

This is the only case in which a newsroom representative was strongly involved in the DNI project. Another interviewee, however, reports on a grant that the publisher, following the discontinuation of the DNI Fund, received from its successor programme, the Google News Initiative (GNI), to establish a new YouTube format. The newsroom was involved as a matter of considerable necessity in this case:

The editorial team is not involved in technology projects. The only one it is involved with is the YouTube project. Because it was explicitly an editorial YouTube format. In this case, the editorial team was part of the brainstorming process.

[The source identifier is omitted here to protect the anonymity of the interviewee.]

Based on the interviews, internal opposition to the DNI projects was extremely rare. Two interviewees report criticism of Google funding from the editorial team [J6, P12]:

There's always a big discussion about whether to accept money from Google, Facebook, and so on. Whenever someone says 'OK, here's a grant of 100,000 euros,' you have co-workers who then question whether it's necessary and whether there aren't other sources of funding. [J6]
Among the interviewees at least, this did not, however, result in any decisions against applying to the DNI Fund:

The editorial teams were just observers. The people in the newsroom who understand technical things are, of course, critical of Google. On balance, the newsroom is quite divided on the Google issue. But then again, they weren't really involved. It's a matter for the publisher to decide.

[P12]

\subsection{Impact on independence}

Finally, we would like to discuss how the digital journalists and managers we interviewed assess the impact of DNI funding on their work in the media.

\section{Views on Google's motives}

A prerequisite for a proper assessment of Google's funding programme and its potential influence on editorial independence is an awareness of the interests that Google may be pursuing in the process. The interviewees were therefore asked about their assessment of Google's motives.

Irrespective of whether or not their organisation received a grant, all the respondents believe that Google is pursuing its own strategic interests with the DNI Fund and its other funding operations for the media industry. The exact nature of these interests, however, is a contested issue. While several interviewees $\left[\mathrm{P}_{4}, \mathrm{P}_{9}, \mathrm{~J}_{5}\right]$ cite the further establishment of 
Google products in the media industry as a potential objective, one journalist [J7] sees a possibility that Google may be trying to guide the technical development of the industry by strategically financing specific projects.

Adopting a similar opinion, another journalist believes that while Google's aim with its innovation grants is not necessarily to control the industry's development, it may still be interested in keeping a close track of this development to secure opportunities to invest in promising technology innovations as early on as possible. Given the legal conditions attached to the funding projects, this is a credible possibility: the terms and conditions for the Digital News Initiative stipulate that project participants retain the intellectual property rights to all products they develop, but Google is still legally entitled to develop or acquire related or similar products itself without fear of legal consequences (Google News Initiative 2018: 6f).

One publishing manager sees the News Initiative as a way of exploring market potential:

Despite all the hand-wringing, the media is a high-revenue and indeed profitable industry. It's a very subjective assessment and I don't have any evidence, but Google will at some point have worked out whether it's possible to generate growth here. This means you need to have the right customer contacts and the right products. So they're slowly making inroads into this market, taking a trial and error approach to see what works and what doesn't. Google holds out a bit of money and lets swarm intelli- gence work with it. The objective, however, will most likely be to crowd others out and generate high-margin business.

[P14]

The media professionals we interviewed most frequently characterise Google's News Initiative as a marketing or PR strategy $\left[\mathrm{P}_{1}, \mathrm{P}_{3}, \mathrm{P}_{4}\right.$, $\mathrm{P}_{5}, \mathrm{P} 8, \mathrm{P}_{10}, \mathrm{P}_{12}, \mathrm{P}_{13}, \mathrm{J6}, \mathrm{J}$, J10]. Four interviewees believe that the goal is not necessarily to win support among the media, but may still involve a desire to create understanding for the company's actions $\left[\mathrm{P}_{2}, \mathrm{P}_{5}, \mathrm{~J}_{3}, \mathrm{~J}\right.$ ] $]$. One broadcasting manager says that Google's improved ties with the media industry may allow it to take note of and effectively counter criticism at an early stage. A journalist puts it like this:

They hope that this will lead to a critical engagement with Google and its products [...], so that we get a feeling for how the company operates. What makes Google tick should be implicitly clear, without them having to spell it out.

In this context, several respondents see a connection to the discussion on the introduction of an ancillary copyright law for press products [P4, P8, P10, J8; see Chapter 4.1]:

It's certainly not a coincidence that Europe is no longer [i.e. following discontinuation of the Digital News Initiative in 2019] at the centre of their concerns. I'd say that they just wanted to buy some goodwill and show that they're making an effort when confronted by the spectre of 
the ancillary copyright law. Just like Springer on the other side of the divide, Google also lobbied for its interests. And here, I really can imagine that it was a form of flattery so that they'd say, maybe Google isn't that bad after all.

At the same time, a number of interviewees believe that Google acted out of its own interest in a healthy media industry. "If we're being naive, we could say that Google is ultimately interested in having good content on the web," says the digital manager at a large publisher [P11]. As noted by a journalist from an organisation that received a grant, this is one way in which Google itself wishes to portray the News Initiative to the outside world:

And of course people ask you why you're doing it at all. Then Google says, we want our users to find good, high-quality content. That's why we support journalists and the news media. It's how Google sells the initiative.

In this respect, Google itself talks about a healthy "news ecosystem" (see Chapter 4.4), a view shared by several respondents $\left[\mathrm{P}_{2}, \mathrm{P}_{7}\right.$, P13, J10]:

I think that Google's business model makes it important for there to be effective journalism providing information. Its business functions through user engagement on the internet, with its search engine, etc. Journalism is a part of the overall ecosystem in which Google operates. [P7]
A journalist and a publishing manager use the catchword "responsibility" in this regard:

You have to acknowledge that they were the first to hold out some money and say, 'we're going to shoulder some of the responsibility for this ecosystem'. Not entirely without self-interest, obviously. They were hoping it would buy them some goodwill. And maybe they also hoped that publishers would be less hostile towards Google on other issues.

[P13]

The journalist here is implying a form of redress and some contrition after Google had "ruined" publishers' online advertising businesses. They compare the DNI Fund to the development aid western nations give to poor countries, and imagine that Google saw it like this:

Now we need to put some money back into the system. But instead of just transferring cash to the media, we'll do it like they do for the developing world. We'll support good projects and do our best to achieve some kind of tradeoff. So we'll try to preserve the ecosystem or the biotope of journalism, because, as a search engine, we profit hugely from it. And in the process, we may be able to buy ourselves a clear conscience.

\section{No signs of editorial interference}

At no point in any of the interviews did anyone claim that Google had attempted to influence them with its DNI Fund. On the contrary, many of the respondents whose media organisations received Google funding rejected even 
the notion that they might have been manipulated. The manager of a large national media organisation is cited here as a typical example:

That's a very dangerous question. I'm not sure if what you're saying is that it would be possible somehow to undermine or otherwise influence the editorial independence of [name of the media organisation]. It's simply not possible! Independence is our most precious asset. I feel it's important to state that clearly.

They add that Google representatives had never tried to exert any direct influence, and that it would be impossible in any case. In this context, some interviewees point to reports critical of Google that appeared in their media, despite having received $D N I$ funding $\left[\mathrm{P}_{1}, \mathrm{P}_{7}, \mathrm{~J}_{1}, \mathrm{~J}_{5}\right]$.

Discussions with interviewees whose media did not receive any DNI funding corroborate this finding: none of them had heard reports or even rumours about attempts to exert direct influence.

The interviews also give no indication of any internal attempts by publishers or editors to improperly influence journalists' reporting on Google. All of the interviewed journalists denied any kind of interference beyond the normal editorial discussions with their chief editors.

\section{Self-censorship concerns}

What the digital journalists do point to, however, is the possibility that the inroads Google has made into the industry could allow it to exert an implicit influence on media cover- age. Such close ties could reduce journalism's “bite" and inhibit criticism [J1, J8, J10, J11].

Whenever a company starts handing out money and taking a high profile, it's bound to win some support. It's just like when you actually speak to politicians. Coming together like this inevitably quells criticism, because you naturally develop empathy for the other side and can see things from their perspective. That isn't necessarily a bad thing, either. This kind of PR work isn't improper or unfair. [...] So it does bring about some change. Naturally also a change of perception among journalists. But the question is, is that an improper change of perception? I haven't seen anything yet to suggest that it is.

It's always a good idea to maintain contact with media companies. If need be, you can always call up and say, for example when it comes to ancillary copyright, 'Would you take a look at this? And what about that? Have a think about seeing it this way.' These ties can corrupt when people know each other personally and are part of a network.

One journalist who works for a public service media organisation believes that Google's project funding may have a harmful influence on press independence, even if the company does not have a direct say in what is reported:

It's not that Google would say, 'we'll give you money, but in return you mustn't write anything critical'. I really can't imagine that happening. 
What's more likely is that people will actually censor themselves and say, "no, come on, they gave us so much money and it's a great project. Let's not go overboard.'

A digital journalist from a large German national media organisation conveys something of the difficulty in understanding this form of influence in traditional terms:

We're seeing a new kind of influence with the News Initiative. Understood the old way, if you look at the Press Code, say, it's actually alright. Because they don't try to influence our content. But they're still buying something. And I think that we don't yet have ways to fully understand that.

A moment later, the same journalist offers their interpretation of this influence, based on the business model of online platforms:

I've been doing this for a while, you know, and I think that Google's influence has increased in the last 10 years, but at the same time has become more subtle. [...] That's the perfect description of platform capitalism. At the start, we added products to a network - whether it was social media or AirBnB - because we thought that everyone would benefit and the platform providers would have no influence on our content. And then you had this creeping realisation: Oh, the chronological timeline isn't so important any more. Oh, they rate and sort things using criteria we no longer understand. Oh, they're influencing us after all. It's a classic platform dilemma, and we're seeing it here in the form of business funding. And it's something of a problem, as they've manoeuvred themselves into a smart position and act like they don't try to influence us at all. From a strictly legal standpoint, you'd have to say, yes, it's true, Google doesn't tell us what to investigate. But they're still now embedded in our core business. Just like a platform is part of a business if you use to it to deliver content.

The journalists whose organisations received grants from the DNI Fund, however, claim that their and their colleagues' work is still not in any way compromised $[\mathrm{J} 1, \mathrm{~J} 2, \mathrm{~J} 5, \mathrm{~J} 6, \mathrm{~J} 7 \mathrm{~J}$ :

Yes, I had my doubts. But when I heard more about the product, I realised I didn't have a problem with it in this case. Also when I found out how much money it was, because it really wasn't that much.

I wouldn't say it had any influence on my work in the newsroom. Certainly no more than with any other kind of cooperation - after all, publishers do cooperate with other companies. And then there are companies who place ads with us. There are events that are sponsored by some company or other. [...] At the end of the day, we're not a charitable organisation. [...] I don't see us somehow becoming dependent on Google. I might be concerned if Google were the only source of funding. I think doing these data projects was a means 
to an end. That's why I don't think that anyone was ever compromised, not least because I know the people on the project. But the only way to be really sure is not to take the money. [J6]

No, Google never tried to influence us. But I don't think I can say that they never will. If it becomes more all-encompassing and the paper is then crucially dependent on Google's good will, well, that may well be problematic at some point.

The point made by this journalist [J1] is corroborated by two other interviewees, who say that press independence may or may not be undermined depending on whether the funding received is a one-off, repeat, or even a regular payment [J7, J11]:

Over the long term, I don't see any risks for a one-off project; it's a different matter if a company were to receive grants for years, which might even make jobs dependent on the Google budget. That would increase the likelihood of our compromising independence and be the point at which I said, it'd be better if we didn't let it come to that.

Even though Google provided project-related grants rather than ongoing structural support to European media organisations through the DNI Fund, there are still many organisations that were given several grants over three years (see Chapter 5.1).

\section{The Digital News Initiative as a lobbying tool} In terms of editorial independence, there is evidence to suggest that Google used the Digital News Initiative as an enabler on regulatory issues, allowing the company to push its own political interests. In June 2018, the Financial Times reported on an email sent by Google manager Madhav Chinnappa to the DNI Workgroup, a group of publishing managers (Garrahan/Kahn 2018). In that email, Chinnappa sets out the potential impacts of EU copyright reform, at the time under negotiation, and specifically addresses the issue of a European ancillary copyright law. Such a law would "impede the free flow of information" and thus harm journalists and other creators and producers of news, he writes in the body of the email (Chinnappa 2018), adding that anyone who feels strongly about the issue should contact their MEP on the EU Parliament's JURI committee.

The European Innovative Media Publishers platform (EIMP) was established during the debate on an ancillary copyright law (see Chapter 4.1). In contrast to the majority of news publishers, who see ancillary copyright law as a way of holding Google financially responsible for its actions, this platform chiefly argues against the introduction of any ancillary copyright law. Almost all the media organisations listed as supporters on the EIMP website have received money from the DNI Fund. When the authors of this study contacted Google to ask whether it was involved in the establishment and work of the EIMP (see Appendix A), the company confirmed that it provides direct support to the platform: 
We support a number of interest groups and research programmes around the world to help public and private institutions pursue research on important topics in computer science, technology, and a wide range of public policy and legal issues. That includes EIMP that helps give smaller publishers a voice.

[Statement by Google in Appendix A]

The manager of a large news publisher [ $\left.\mathrm{P}_{2}\right]$ says in interview that Google also pushed its own position in another EU legislative procedure. The EU's proposed ePrivacy Regulation of 2017 aimed to replace an older Commission Directive on protecting electronic communications. As desired by the Commission and the European Parliament, the Regulation would strengthen data protection standards when surfing the web. The advertising industry, however, was concerned that this would make it more difficult to collect data for personalised advertising. The publishing manager describes Google's approach to the issue as highly significant to their own business:

What the browser developers do - Apple, Mozilla, or indeed Google - is of course enormously relevant to our business model. It's an issue we have to look at very closely. As an example, if the browser developers stop allowing cookies in anticipation of an ePrivacy Regulation, that would have a huge impact on our business.

According to the interviewee, Google sent information on the ePrivacy reform to participa- ting publishers, noting that it could "impact on your business". When asked to comment (see Appendix A), Google did not deny this. The company stresses that its statements on ongoing legislative procedures are common practice:

We build technology that helps people and creates economic opportunity. Our success in doing that means we have a responsibility to be an engaged and helpful partner to policymakers as they debate topics related to our products and partners. That also applies in regulatory enforcement cases. We have made our case to regulators and others involved in the process, and we'll continue to do so.

[Statement by Google in Appendix A]

Google thus uses its News Initiative not only to maintain relations with the media industry, but also as an argument to lobby the EU Commission in Brussels. This is made clear by a series of EU Commission documents obtained by the authors of this study through requests for information under EU Regulation 1049/2001 (FragdenStaat.de 2019b). The documents suggest that Google uses the Digital News Initiative to push its own arguments at high-level meetings. These meetings took place in the context of attempts to subject Google and other digital companies to stricter regulation (see Chapter 3.1).

One example is the meeting of Google representatives with EU Commissioner Mariya Gabriel in February 2018, at which the company wanted to address the Commission's concerns 
regarding the spread of "fake news" and disinformation on social media platforms. A preparatory briefing by the EU set out possible topics for the meeting, among them the Digital News Initiative. In earlier emails to the Commission, Google had lauded its initiative. According to the meeting minutes, Google referred to its "partnership" with publishers during the meeting with the Commissioner, adding that the company helps them to monetise their content and develop new business models through subscriptions. At the same time, Google opposed any new regulation at the meeting, according to the Commission's minutes.

\subsection{Interim summary: Google's millions for the media industry are not without consequence}

This chapter has been devoted to the second and fifth research questions of this study: it used interviews and data analyses to investigate how the millions of euros Google has given to media companies within the Digital News Initiative were distributed, what impact they had, and whether this posed a threat to press independence.

\section{Google's media funding in Europe: Money to incumbents}

The DNI funding data analysis shows that Google's millions were not evenly distributed in Germany and Europe; instead, we see a number of disparities, with considerable difference between regions, recipient groups, and project types.
Most of the money went to western European countries and their high-revenue media industries. Heading the table of recipient countries is Germany, which received a total of $\mathbf{2 1 . 5}$ million euros. It is followed by France (estimated at 19.5 million euros), the UK (estimated at just under 15 million euros), Spain (estimated at 12 million euros), and Italy (estimated at around 11 million euros). The recipients are also dominated by established commercial media organisations. While only around six percent of DNI funds were disbursed to non-profit media (around six million euros), almost 75 percent went to commercial media (some 100 million euros). There also appears to be a clear preference for projects relating to data and robot journalism.

Despite its claim to promote innovation, the News Initiative cannot be described as a stimulus programme for journalism start-ups. Fifty-four percent of organisations that received funding are more than 20 years old, and they received a good 70 percent of the large grants over 300,000 euros. Funding recipient organisations established since 2010 account for 31 percent of all grants, but the majority (58 percent) received only small grants of up to 50,000 euros. All in all, the typical beneficiary of DNI funding is an established, commercial, western European publisher.

Detailed analysis of the situation in Germany further shows that it is not only news start-ups and non-profit media, but also regional publishers that are under-represented. Only four of the 28 large projects to receive funding of up to a million euros in Germany 
were at regional publishers. At the other end of the spectrum are companies such as Dieter von Holtzbrinck's publishing empire DvH Medien $\mathrm{GmbH}$, which alone received up to 5.75 million euros through its publications Handelsblatt, WirtschaftsWoche, Tagesspiegel, and Zeit Online. The Funke Mediengruppe may have been given up to 2.6 million euros, Gruner + Jahr up to 2.3 million euros. Der Spiegel, the only major recipient to espouse complete transparency regarding specific funding amounts, itself received a good 1.5 million euros. A similar sum is likely to have been granted to the Frankfurter Allgemeine Zeitung.

Overall, it may be stated that Google's funding of the media industry is guided by existing economic structures and probably even works to reinforce them: the rich get richer. By contrast, there is no evidence to suggest that the DNI Fund serves the common good - after all, no financially weaker media organisations or non-profit journalists received grants. Nor does it aim to close gaps in press coverage throughout central and eastern Europe to help bring about greater balance in European public life. On the contrary, existing disparities are widening.

\section{A threat to independence: no direct influence, but possible self-censorship}

For those organisations that receive funding, however, Google's injection of funds is often a blessing. As dramatic as it sounds, innovation is impossible without Google, at least based on the findings of this study. The interviews with German digital journalists in Chapters 5.2 and 5.3 show that the data giant is plugging a yawning gap with its funding programme. Publishers, in particular, clearly state that DNI funds have been and continue to be of great importance to their own innovation projects.

Many of the interviewed media organisations say that the DNI grants were crucial to their innovation projects. Even if some of those projects did not turn out successfully, the corporation's initiative in itself prompted many media companies to reflect on the issue of innovation and try out new approaches in a spirit of experimentation. In this light, it is doubtful whether the German publishing industry would be where it is today in terms of digital innovation had it not received this support.

There is good news when we come to the question of personal and editorial independence: the study finds no indication of any direct attempts by Google to influence individual journalists or entire newsrooms through its Digital News Initiative.

Nevertheless, several interviewed journalists believe that it may increasingly act as a brake on criticism of the data corporation. One respondent speaks of "compromising ties" to Google. Some express concerns that this problem may occur if an organisation receives multiple grants or where Google money represents a significant share of a company's income. This point is particularly important, given that Google not only continued its journalism funding programme following the ending of the European News Initiative in 2019 but has actually now rolled it out worldwide: the cash injections it provides are becoming a fixed el- 
ement in the financing of technical advances on which media companies are increasingly dependent in their business development plans. The risk of self-censorship to avoid upsetting a key funding partner is likely to grow the more Google's funding becomes an established part of the ecosystem.

In terms of the separation of publisher and editor roles, considered a "firewall" to protect newsrooms from outside influence, the study reveals a disparate picture. While a number of interviewees stress the necessity of involving editorial teams on tech projects, others say that newsrooms are deliberately kept away from the DNI projects. This appears to be easier at larger media organisations. At one smaller organisation, journalists reporting on Google were in charge of the project financed by Google. As technology advances in newsrooms, journalists are likely to be involved in development projects more often, suggesting an urgent need for a discussion of how to approach these issues from a current perspective (see Chapter 8).

Finally, at the publishing level, there are indications that Google used the initiative to lobby on regulatory issues. Two known cases exist in which the company evidently used its "special relationship" with publishers to promote its own political positions. Thanks to close relationships and good contacts in the publishing world, the News Initiative is becoming Google's vehicle in the battle to regulate the digital world. 


\section{Conferences, training, fellowships}

The pallet of support measures that the data corporation provides to the media industry covers not just the direct funding of projects through the Digital News Innovation Fund (and its successor, the GNI Innovation Challenges), but also sponsorships, the organisation of industry events, and the award of fellowships and training courses to journalists (see Chapter 4 ). This chapter turns its attention to these aspects, with the aim of answering the following research questions:

3. How did German news media organisations benefit from events, training, and fellowships financed by Google?

5. What threats do these ties pose to the independence of the news media and journalists - at individual, editorial, and publishing levels?

A combination of different analysis methods will be applied to shed light on the various ways in which Google has been supporting the journalism industry in recent years and show how the industry in Germany has reacted to them. To this end, Chapter 6.1 initially sets out the extent to which these funding elements are used in Germany on the basis of online and literature research, a written survey of a number of German media organisations, and in-depth interviews with digital managers and journalists. This is followed by an evaluation of the interviews for potential threats to press independence.

\subsection{Google as industry platform}

\section{Conferences}

In addition to its direct project funding through the Digital News Innovation Fund, industry events are a key element of Google's involvement in the media industry. The company thus regularly organises global and regional summits within the News Initiative, inviting funding recipients to London, Amsterdam, or Berlin. One respondent $\left[\mathrm{P}_{5}\right]$ also reports on funds from the News Initiative that were provided for independently organised regional events.

The most prestigious of Google's events for the media industry is "Newsgeist," an "unconference" that Google organises - together with the Knight Foundation in the US, on its own in Europe - to bring together "practitioners and thinkers from the worlds of journalism, technology, and public policy," as it claims on the event website (newsgeist.org, undated).

Google also acts as a sponsor of numerous independent industry events. This study cannot provide a full summary of its commitments but will instead here endeavour to provide a few select examples: in 2019, Google sponsored the "Besser Online" conference organised by the Deutscher Journalisten-Verband (DJV), the prestigious International Journalism Festival in Perugia, Italy, the Medientage Munich conference, the Global Investigative Journalism Conference hosted by Netzwerk Recherche and the Global Investigative Journalism Network in Hamburg, and the GEN Summit of the now de- 
funct Global Editors Network. Many of these events were sponsored not just once but over several years by Google (and other tech companies such as Facebook). The same is true of digital conferences such as re:publica in Berlin, which is not purely a media conference but is still attended by a large number of journalists. Google also regularly (co-)funds industry awards for data journalism such as the Sigma Data Journalism Awards and the Data Journalism Awards run by the Global Editors Network.

In the written survey of German media companies, 14 of 22 participants stated that their employees had attended conferences or other industry events organised or funded by Google. They cited Newsgeist and conferences organised within the Digital News Initiative and Google News Lab, as well as the Google Cloud Summit, a Google product fair, and the Data Journalism Awards co-funded by Google.

The oral interviews reveal that 8 of the 11 interviewed journalists $[\mathrm{J} 2, \mathrm{J3}, \mathrm{J4}, \mathrm{J} 5, \mathrm{J7}, \mathrm{J8}, \mathrm{J} / \mathrm{J}, \mathrm{J} 1 \mathrm{O}]$ attended industry events organised or primarily funded by Google. Two further journalists [J6, J11] state that the opportunity had simply not yet arisen, but one of them plans to attend out of "research interests".

Many of the publishing managers also attended events organised or funded by Google, with 9 out of 14 interviewees saying they definitely participated $\left[\mathrm{P}_{2}, \mathrm{P}_{3}, \mathrm{P}_{6}, \mathrm{P}_{7}, \mathrm{P}_{8}, \mathrm{P}_{9}\right.$, $\left.P_{10}, P_{11}, P_{13}\right]$. Several respondents, however, claim to be unsure about whether they attended events sponsored by Google because their minds were not on the sponsors. This is frequently associated with a sense of pointed in- difference towards the sponsors, because the attendee sees no personal relevance: "Quite honestly, I'm not usually interested in who sponsors events, unless it's just one company." [J2]

Overall, the interviewees almost all see Google's involvement in events and conferences as a positive thing. Typical of many others, executive $\mathrm{P}_{5}$ states that Google has thus created a space that was sorely lacking in the industry:

It was previously the case that the publishing companies in Germany would wall themselves off and never discuss anything together. I'm sure there must have been some clandestine meetings attended by a select coterie of managers. Google has brought this up to a level at which maybe middle management or similar can simply meet up and share views at an event.

[J5]

A more critical view is taken by a journalist who works for a large national newspaper and says they are uninterested in attending such events. Another journalist reports unresolved ethical issues arising from Google's conference funding:

I've been to conferences at which they [Google; authors' note] specifically not being asked to be a sponsor was an issue. There's a huge debate going on among journalism conference organisers as to whether it's right or wrong. I don't think it's easy to say one way or another. [J2] 
A journalist at a media organisation specialising in technology topics states that the value of the events for participants outweighs concerns regarding the corporation's own interests:

Of course I know that Google isn't just doing it for fun. But I still think it's a good thing, a safe space to discuss innovation in the media industry. [...] Naturally they're interested in what's being discussed there and what the media's currently working on.

The respondents are therefore virtually unanimous in stating that Google's involvement in industry events increases the opportunities for media professionals to come into contact with the corporation - above and beyond the traditional press information events that Google also runs in the form of (occasional) press conferences and (frequent) product presentations. At some events at which Google acts as a sponsor, the company is also afforded a prominent position on the programme in return. At the 2019 Journalism Festival in Perugia, for example, Google presented its "Subscribe with Google" product on the main stage of the conference (Fanta/Dachwitz 2019).

In the opinion of many interviewees, the official programme is merely one aspect, alongside the important opportunity to share views and connect away from the conference stages:

They all know each other now. I don't just mean Google's people and their clientele, but generally. It's like a community and that's great. of course the people you know best are your journalist colleagues; if someone from Google sits down at your table, it doesn't bother you, and it doesn't change the conversation that much, either.

Publisher $\mathrm{P}_{3}$ particularly highlights the gettogethers at Newsgeist, at which leading Google employees answer the audience's questions in "Ask me anything" sessions. They state that political topics directly concerning Google are very much addressed, for example relating to copyright reform or ancillary copyright law. $\mathrm{P}_{3}$ stresses that many probing questions are asked and states that the event helped them to better understand Google's perspective:

They really did show themselves to be transparent, and that helped me to better understand their take on things. I don't think it was just spin. They simply explained their point of view. $\left[\mathrm{P}_{3}\right]$

\section{Training}

Google regularly organises training for journalists at various locations around the world and online. Journalists are trained in the use of Google products they require for research and day-to-day work in the newsroom, examples including "Storytelling with Google Earth," "Data Journalism," "Investigative Reporting," and "Verification" (Google News Initiative 2020a). In the process, Google's focus is on multipliers: a "Train the Trainer" programme was developed together with the Society of Professional Journalists and, according to the 
company, has already provided training in the use of Google products to more than 20,000 journalists in the US and Canada alone (Society of Professional Journalists 2020).

Half of the German media companies that participated in our survey (see Chapter 3.2 for methodology) state that their employees have taken part in Google training. In almost all cases, this concerned the use of Google products for research or business purposes; Google Earth, Google Maps, and Google Trends were explicitly named, as well as training on using search engines and Google's ad products.

Of all the publishing managers and digital journalists interviewed, just two state that their organisations had used training provided by Google [J5, J11]. These workshops were held on the organisations' premises, but none of the respondents actually took part themselves.

The interviewees give differing statements as to whether they would fundamentally be prepared to do so. Publishing managers, in particular, are certainly open to the possibility. Examples include $\mathrm{P}_{12}$ and $\mathrm{P}_{14}$, who, despite otherwise adopting a highly critical stance towards Google, explicitly say that they could imagine it:

l'd send any journalist there right away. I think that the journalism profession really needs to see some change, because we have much more information and facts now, and correlating this information is crucial. Learning how to do this is one of the great challenges facing journalism. So you should get all the training you possibly can.
Two journalists, J4 and J5, state that they could well imagine participating, while several others express significant reservations about receiving training from Google [J1, J6, J7, J10]. J1 sums up their attitude in a nutshell: "I have a bit of a problem with being taught how to be a reporter by the subject of my reporting." For J10, who works as a freelancer for a public service media organisation, they would only take part if they paid for the training themselves. None of the other respondents stated this or any other conditions for their participation.

\section{Google fellowships}

These fellowships, which were formerly known as "Google News Lab Fellowships" and have now been renamed "GNI Fellowships," allow students of journalism to spend several months working in the newsrooms or product development departments of media organisations. Google pays the salaries of these "fellows".

Four of the media companies in our survey took on News Lab fellows [P11, $\left.\mathrm{P}_{14}, \mathrm{~J}_{1}, \mathrm{~J}_{2}\right]$. Unfortunately, however, none of the interviewees were able to provide more information on the fellows' work or how they were involved in the company's workflows.

An analysis of Google's programme by the authors of this study (see online appendix) shows that, since the time of the first fellowships in September 2016, Google has funded some 50 such places at media organisations in Germany. The company has announced seven further fellowships for the period from July to October 2020. The media organisations listed for the 2020 programme are exclusively those 
that also received DNI funding: Frankfurter Allgemeine Zeitung, Tagesspiegel, Zeit Online, Der Spiegel, Stern Digital, Rheinische Post, and Funke Mediengruppe.

\subsection{Impact on independence}

Google maintains close ties with both journalists and the managements of German publishing houses. More than half of the interviewed publishing managers and journalists say that they maintain regular or at least occasional contact with Google $\left[\mathrm{P}_{2}, \mathrm{P}_{5}, \mathrm{P}_{8}, \mathrm{P}_{9}, \mathrm{P}_{10}, \mathrm{P}_{11}\right.$, J1, J3, J4, J7, J9, J10, J11].

For the journalists, most of their contact takes place at an official level with the company's press staff. Two persons say they are privately in contact with Google employees []1, J10]. Beyond this, the conferences that Google hosts or funds are cited as forums for more informal discussions with the company's employees $\left[J_{3}, J 7, J 9\right]$. One journalist says they visited the company on a trip to the US with their journalism school. Several journalists stress that their contact with the company is limited exclusively to reporting [J4, J8, J11].

Publishers, by contrast, consistently approach Google to discuss the needs of their businesses. One innovation manager at a large press publishers puts it like this: "Of course we talk to each other. And yes, we regularly talk about what we want." $\left[\mathrm{P}_{10}\right]$

The manager of a large online media organisation stresses that conflicting interests are part and parcel of their dealings with the tech corporation. The relationship crucially hinges on the question of whether views can be freely expressed:

The question is, how do you talk about them? Is there even a space where we can talk about it? That doesn't mean that they'll do whatever you want.

The publishing manager at another large company maintains that political differences are no barrier to business relations:

Of course they [company colleagues] are in contact with Google. You need to avoid falling into the proverbial trap. We're very critical of Google; there are many issues we see differently, but we are of course business partners in all sorts of ways.

[P8]

\section{The appeal of Google}

The interviews generally reveal a certain degree of ambivalence towards Google within the media industry, with almost all respondents alluding to the negative economic impacts of the company's services. When asked to name positive aspects of the company, however, a number of interviewees see Google as an example to be followed in a range of areas. One, for example, puts it like this:

What Google really is good at is being incredibly innovative and investing in many different areas. And, again and again, finding good business models. I'm sure there are many who'd do well to take a leafout of their book. I believe that smart people work for Google.

[P9] 
In addition to the corporation's capacity for innovation, there is also a strong awareness of its cultural impact. Some of the interviewees describe Google's corporate culture as a model for journalism:

In terms of diversity, I think they have pretty good recruitment strategies. At least based on what I've read. And I have been to see and report on a number of Google institutions. I think they're also quite progressive when it comes to their work culture, say, in the mixture of hierarchical and agile structures. That's also very modern, I think.

The flat hierarchy, the focus on results, and yet so much creativity. As a newcomer to this industry, you're surprised by how hierarchical and rigid the media is. Learning a few working methods from this agile environment would do journalism good. As would, to a certain extent, disrespecting hierarchies.

[P14]

There are, however, some dissenting voices. One publishing manager, for example, says that they reject positive views of Google and other tech companies in the industry:

I'm no friend of Google's. At the end of the day, I'm completely agnostic about Google, Facebook, etc. I take a businesslike approach to these companies.

[P10]

The manager of a national publisher offers a more nuanced opinion. Despite words of praise for the company's capacity for inno- vation, its dominant position in the market is criticised:

Of course Google's a great company. And of course it's an innovative company, there's no doubt about it. They do some things right, otherwise they wouldn't have become so big and successful. [...] But we very much believe in healthy competition. And that, of course, is lacking. l'd warmly welcome Google as just one market player among many others.

[P8]

\section{"Google's a bit different to Facebook"}

Publishers see Google in a far more positive light than other digital companies, especially its rival in the global competition for online advertising, Facebook. This is particularly remarkable given that Facebook has adopted Google's model and now also supports journalism with its own funding programme (see Chapter 3.4). Respondents cite a clear ideological difference as the reason for their contrasting views of Google and Facebook:

To me, Google's a bit different to Facebook because Google supports and encourages an open ecosystem with its search engine and indexed content. In other words, how easy it is to search for and find content. I'm old enough to remember the internet before this existed. Facebook and others, by comparison, are of course closed ecosystems.

$[\mathrm{P} 1]$

Google is a search engine. It can sell advertising well if the search engine works well, and the search engine depends on an open inter- 
net. Facebook set up a walled garden 20 years ago. They want to get people in their ecosystem and keep them there. That's why I believe that Google is better for the industry than something like Facebook. Facebook would find it harder to work out how its business model can be combined with a paid content business model.

One publishing manager justifies their aversion to Facebook as a company by citing the increasing irrelevance of its social network to generating audience traffic:

Facebook no longer drives traffic to us like Google does. Facebook is more volatile, l'd say, and it's harder to understand the logic behind how it adjusts its News Feed. The notion of a partnership is even less pronounced there.

Even journalists who report on digital companies have a much higher opinion of Google than they do of Facebook. As two interviewees state, the media appearances of the latter company's top personnel are one reason for this [J1, J8]:

It terms of social cohesion, I see Google as the less dangerous company. Simply because it has shown greater prudence, care, and, so to speak, morals in the past than Facebook, which has seen many more scandals and faux pas than Google, as I see it. [Google doesn't have] a hate figure like Mark Zuckerberg who comes out and says no, we won't remove Holocaust denial content. [...] It's idiotic, of course, to say such a thing in public. Mark Zuckerberg has a talent for being a hate figure. I think that's much more significant than the question of who is spending how many millions on PR. With Google, I wouldn't know whom to hate.

Other interviewed journalists state that the two companies' conduct affects how they trust them:

There are good reasons why we feel more inhibited about talking to Facebook than we do with Google and YouTube. It's just my opinion, but Google and YouTube are not as brutally capitalist as Facebook. There's no way you can trust Facebook; I feel that Google manages this problem much better. For example, its adherence to data protection laws and its services for individuals allowing them to view their accounts and change settings. It's not that it's perfect, but they were much more open and offered more options a long time before Facebook ever did. [J4]

I think that Facebook's superfluous. Personally, I find Facebook's market and business practices abhorrent. And they way they communicate. I'm completely ambivalentabout Google.

\subsection{Interim summary: "community building" powered by Google}

The interviewees cited in this chapter are clearly of the opinion that the numerous events Google organises and sponsors make the company an important force for networking the media industry in Germany and Europe. As they 
say, Google has increased the opportunities for media companies to interact and contributed to strengthening the industry's network, in the process itself becoming a kind of platform for journalists and publishing managers.

The funds the company provides for training and development are another important factor. Since 2016, Google has funded at least 50 fellowships in the newsrooms and development departments of German publishers, which have helped launch a number of careers. In the process, both the editorial departments and the young journalists they take on benefit financially. Google pays the latters' salaries and also opens doors to prestigious potential employers.

In terms of the research questions, this means that Google's funding of conferences gives it a very strong hand in shaping opinion within the industry and in the context of training. This dominance may well arouse suspicions that the company has an indirect impact on journalists' independence.

At the individual level, it means that Google is helping to launch the careers of a new generation of journalists and ensuring continued loyalty through conferences. For the individuals concerned, this may not necessarily result in direct dependence, but it does work to shape their CVs in a way consistent with Google's aims.

By contrast, only a few interviewees had attended training organised by Google, and they see little risk of it posing a threat to their freedom of expression.

At the editorial level, there is growing acceptance of training positions funded by Google, of the company's training programmes, and its hosting of conferences. The positive effect of these elements can be seen in the interviewees' high opinion of Google compared to other companies such as Facebook.

At the editorial and publishing levels, it is clear that Google's training and conferences exert a clear influence. Google's pervasive presence at media conferences allows the company to take a leading role in industry conversations. These, of course, include discussions about Google's impact on journalism. The authors can assert that the tech corporation has de facto limited the media industry's ability to engage in self-reflection to some extent. This "community building" also creates what we might call an intimate relationship between Google, publishing managers, and journalists. 


\section{Economic and technological ties}

The complex ties binding Google and the news industry do not end with the company's altruism highlighted in the preceding chapters. Instead, for many publishers, Google is at once a technology provider, a business partner, and a competitor. This chapter is devoted to examining this complex of economic and technological ties, which will serve to answer the following two research questions:

4. To what extent do news media organisations and journalists in Germany use Google products as part of their technical infrastructure?

5. What threats do these ties pose to the independence of the news media and journalists - at individual, editorial, and publishing levels?

To this end, Chapter 7.1 begins by assessing the in-depth interviews with publishing managers and digital journalists, as well as the written survey on the use of Google products at German media organisations. Chapter 7.2 goes on to summarise observations from the in-depth interviews on the impact of these ties on the independence of the media.

\subsection{Google's services as infrastructure for the industry}

\section{Survey on use}

In order to understand the technological dependence of the German media on Google on the basis of empirical findings, an online survey of 173 German media organisations was conduct- ed for this study. As set out in Chapter 4.2, the survey took place during the coronavirus crisis; a total of $\mathbf{2 2}$ media companies ultimately chose to take part. The findings make no claim to be statistically representative, but they may be taken as a sign of how widespread Google's products and services are in the industry.

The survey was completed by smaller and regional news organisations and specialist media, as well as by a number of large national press publishers. None of the media companies can manage entirely without the use of one or more of the 30-plus Google products mentioned. The responses indicate that Google and its services are very important for digital audience acquisition, as well as for dayto-day newsroom workflows and the financing of media companies through advertising (see Table 9).

The product most commonly used is the Google search engine: just two of the 22 surveyed organisations say they do not use Google as their standard search engine. Other services, too, are an integral part of day-today editorial work. At 16 of the surveyed media companies, Google's Chrome browser is pre-installed on business devices or used by many employees out of choice. More than half of the respondents say they use Google Maps (13 respondents) and Google Translate (12 respondents) for visualisation and research purposes. Also widespread is collaborative work using Google services: nine media companies say that their employees use the Google Hangouts video messaging app at least occasionally; in each case at six companies, employees 
frequently or occasionally use the Gmail service and the Google Calendar service for communication and scheduling. Eleven organisations state that they use Google Docs or G Suite for collaborative work on articles. Eight media companies use Google Drive for in-house storing and sharing of data.

Among the respondents, 17 or around 77 percent say that their organisation has one or more employees whose work often or primarily involves optimising content to make it easier to find in the search engine, known in the business as search engine optimisation (SEO). In almost all cases, this means optimising content for the dominant market player Google Search - according to the EU Commission, Google accounted for more than 90 percent of all searches within the European Economic Area in 2016 (European Commission 2019). Eighteen of 22 surveyed organisations state that they use services such as Google Analytics, Google Tag Manager, and Google Search Console to analyse page views and user behaviour.

Ultimately, Google services help to generate revenue at the vast majority of news organisations we surveyed. Fifteen of twenty-two media companies, or more than two thirds, use Google Adsense, Google AdX, or a similar Google product for ad monetisation. Three institutions state they work with Google Publisher Center, which publishers and other providers can use to submit, manage, and monetise their content on Google News. With one exception, all of the organisations say that they also deliver content through YouTube. Ten of them take advantage of the opportunity to share in advertising revenues; another four did not provide any details. In addition, 17 organisations offer apps on the Google Play Store, some of which provide monetisation opportunities. Less widespread, however, is the use of Subscribe with Google or the conversion feature in Google Analytics for generating revenue through subscriptions - just two of the media companies say they use one of these two products. The answers suggest that Google services are not used at all to monetise content at only 5 of 22 surveyed media companies.

The corporation's services are also used to produce and deliver content. Fourteen organisations state that they use Accelerated Mobile Pages (AMP), PageSpeed Insights, or other Google services to optimise their websites. Two of these host their AMP sites directly on Google servers; seven respondents say they do not and another five provide no information. Four organisations state that they use Google Fonts, Google Hosted Libraries, or other Google libraries to deliver web content. By contrast, none of the surveyed organisations use Newspack, a content management system (CMS) developed by WordPress.com and the Google News Initiative, or other Google content management services to create and manage content on websites and social media.

Google is also involved in the technical security of news services: some respondents use Google Sign-In to identify website users (two respondents), Google Authenticator or a similar Google service for log-in security (four respondents), or reCaptcha or a similar Google 


\section{Table 9}

Use of Google products in German newsrooms

\begin{tabular}{|c|c|c|}
\hline Queried Google service & Category/use in journalism & Users (of 22 media companies) \\
\hline Google Search as standard & Content dissemination & 15 \\
\hline Search engine optimisation & Content dissemination & 17 \\
\hline Gmail & Content production & 6 \\
\hline Hangouts & Content production & 9 \\
\hline Calendar & Content production & 7 \\
\hline Drive & Content production & 8 \\
\hline Docs, G Suite & Content production & 12 \\
\hline Chrome as standard & Content production & 16 \\
\hline $\begin{array}{l}\text { Analytics, Tag Manager, } \\
\text { Search Console }\end{array}$ & Content dissemination & 18 \\
\hline AdSense, AdX & Monetisation & 15 \\
\hline $\begin{array}{l}\text { Subscribe with Google, } \\
\text { Conversion in Analytics }\end{array}$ & Monetisation & 2 \\
\hline Apps on Play Store & Dissemination, monetisation & 17 \\
\hline Content on YouTube & Content dissemination & 21 \\
\hline Advertising on YouTube & Monetisation & 10 \\
\hline Nest, Assistant (audio content) & Content dissemination & 1 \\
\hline Newspack (CMS) & Content production & 0 \\
\hline $\begin{array}{l}\text { News Publisher Center, } \\
\text { News Producer }\end{array}$ & Content dissemination & 2 \\
\hline $\begin{array}{l}\text { Accelerated Mobile Pages (AMP), } \\
\text { PageSpeed Insights }\end{array}$ & Content dissemination & 14 \\
\hline AMP hosted on Google & Content dissemination & 2 \\
\hline Fonts, Hosted Libraries & Content production & 4 \\
\hline Maps, Earth & Content production & 13 \\
\hline Translate & Content production & 12 \\
\hline Authenticator & Security & 4 \\
\hline Sign-In & Security & 2 \\
\hline reCaptcha & Security & 2 \\
\hline Google Shield & Security & 0 \\
\hline Google Cloud & Production & 1 \\
\hline
\end{tabular}


service to prevent bots from interacting with their site (two respondents). One of the surveyed media organisations used Google Shield, at least for a time, to protect itself from distributed denial-of-service (DDoS) attacks that disrupt websites by flooding them with requests.

\section{Interviews: a variety of relationships} with Google

Several interviewees attest to a wide-ranging business relationship between their companies and Google [P9, $\left.P_{10}, P_{11}\right]$. One manager of an outsourced innovation department summarises it like this:

Google is a marketing partner. But they're also a development partner, working closely with colleagues who trial new products, who are responsible for introducing new products to the German market. They're relatively fast when it comes to thinking about how we can deliver our services to specific platforms. We have very many different points of contact with Google. [P9]

One of the original objectives of the Digital News Initiative, to offer a discussion platform for Google and publishers, appears clearly fulfilled, at least in the eyes of some managers at larger media companies: they single out Google's willingness to engage in dialogue with the industry for praise $\left[\mathrm{P}_{1}, \mathrm{P}_{2}, \mathrm{P} 6, \mathrm{P}_{11}\right]$. The Digital News Initiative, as they say, has helped to establish a forum in which German publishers can tell Google about their needs and require- ments. One publishing manager characterises this as a concession on the company's part:

It's like this: if the big market players want to flex their muscles and punish digital publishers, they can do so without ever having to talk to us. An open ear, and the dialogue itself, are always useful.

One manager at a broadcasting media organisation sees this dialogue as a helpful process for Google itself. In their opinion, publishers' feedback is part of Google's own product development process:

We're user feedback for them. And if the user feedback is used to make their product better in some way, they do listen, too.

This willingness to take on feedback, however, has its limits, says the representative of a large national publisher. With the introduction of the General Data Protection Regulation (GDPR), for example, the corporation defined for itself the ways in which user consent to process data for the ad tech sector is obtained.

They simply set their own standards. And of course Google is pursuing its own strategy. So it's not like we're talking to each other as equal partners.

[P8]

Managers of smaller press publishers see less willingness on Google's part to engage in dialogue. The digital manager of a regional publisher states that they have never been in 
contact with Google representatives and have never attended any events organised by Google. Asked to name what they would like to see from Google in terms of products, they say:

I've never really thought about what l'd like because I always suspected that Google wouldn't be interested in knowing. Just like Facebook doesn't care about what the kids in the industry want; we're simply too minor-league for them to care.

[P4]

A similar sentiment is expressed by the manager of a small media organisation that received DNI project funding when asked about how Google responds to the needs of publishers:

The way I see it, Google wants to push something into the market. And that's when there's then money or a grant or some kind of workshop or something else along those lines. They simply buy their way to what they want.

The manager of a smaller national media organisation also says that they do not have a contact at Google. When an issue arose with the use of Google's ad services, because the organisation had temporarily been listed as untrustworthy, it took a long time to find a solution to the problem at Google [P12].

\section{Mistrust of subscriptions and job exchanges}

The rapid transformation of the media market is a topic that comes up in almost all of the interviews. There is considerable pessimism when discussing the long prevalent business model of online advertising. The manager of a largely advertising-financed media company $\left[\mathrm{P}_{5}\right]$ says that the main economic objective is to "maintain the status quo" - growth in the digital ad market is not expected. A similar opinion is voiced by the representative of a large German press publisher:

Our digital reach did keep on growing. [...] But that does not equate to higher online revenues. [P8]

Half of the interviewees from publishing houses describe their companies' efforts to boost income through subscriptions and paid content and make themselves less dependent on advertising $\left[\mathrm{P}_{1}, \mathrm{P}_{2}, \mathrm{P}_{4}, \mathrm{P}_{8}, \mathrm{P}_{10}, \mathrm{P}_{11}, \mathrm{P}_{14}\right]$. In the growth market of subscriptions, an ambivalent stance towards Google is apparent. Since 2018, when Subscribe with Google was launched, the corporation has offered a way to sign up and pay for subscriptions with a Google user account. According to Google, customers' data remains with the publishers; the company receives a 5 to 15 percent commission for each subscription (see Fanta/Dachwitz 2019). Several interviewees, who otherwise stress their good relationships with the company, are sceptical about Subscribe with Google, citing worries about their relationships with customers [P2, P8], a desire to retain control over their data $\left[\mathrm{P}_{1}, \mathrm{P}_{11}\right]$, and concerns about dependency on Google [ $\left.\mathrm{P}_{3}, \mathrm{P}_{4}\right]$. The publisher of a news media organisation primarily funded by subscription revenues puts it like this: 
We don't use Subscribe with Google because it makes you into a kind of feature in the Google universe. [...] We are of course present on other platforms, but we try not to do anything that would make us part of someone else's product. [P3]

There is also a great deal of mistrust towards the Google for Jobs enhanced search feature, which has been available in Germany since mid-2019. The small and classified ads sectors have traditionally been a bedrock of press publishers' businesses. In regional newspapers, printed birth, wedding, and death announcements are also a considerable source of reader loyalty. Most press publishers have been trying to adapt this business to the digital age for years. According to a list prepared by the German Newspaper Publishers Association (BDZV), 648 German newspapers maintain classified sections, with 225 of them also operating a job exchange (BDZV 2020).

With Google for Jobs, job vacancies on company websites can now be displayed directly in the search results by adding structured data to the source code. Even given technical hurdles to ensure it functions properly, this feature is threatening the livelihoods of media publishers. Operators of online job exchanges worry that users will be able to access company websites offering jobs directly via Google Search, with no need to use a search portal. The German Newspaper Publishers Association (BDZV) and Springer subsidiary Stepstone filed a complaint about Google for Jobs to the EU Commission back in 2018 (Hoffmeyer 2019).
In the interviews, three respondents $[\mathrm{P} 2$, $\mathrm{P} 4$, P8] name Google for Jobs as a potential threat to their own services. The digital manager of a regional publisher says this is "something we see with a rather critical eye, so when we work together, it's important to think about who is helping whom, and how much" [P4]. With regard to a service with which their company is involved, Google for Jobs is expected to result in a drop of 50 to 60 percent in page views. The representative of a large national press publisher states that Google is a strategic rival when it comes to comparison websites, small ads, and classified ads:

And then, of course, other price or store comparison sites, product aggregators, have a huge problem. It's the same with others. I'm sure that Google will keep doing this until they dominate every segment they can. Right now, it's just a question of capacity.

P8]

Some interviewees report that their companies deliberately avoid the corporation's products. This is particularly often the case with Google Analytics [ $\left.\mathrm{P}_{3}, \mathrm{P}_{10}, \mathrm{P}_{11}\right]$, which is used to measure visitor flows to websites. A manager of a large publishing house adds:

We recently did away with Google Analytics and switched over to Adobe Analytics. We always try to find the best possible service providers with the best terms and conditions at any one time. Google is just one player that you can work with on the internet because they provide a good service. But it's obvious, of course, that you 
shouldn't rely on one single provider. Not making yourself dependent is a basic rule of business.

[P10]

Personal level: everyone uses Google products The majority of publishing managers $\left[\mathrm{P}_{3}, \mathrm{P}_{5}\right.$, P6, P8, P10] and all of the interviewed digital journalists say they themselves use Google products in their everyday work. Even those who describe themselves as sceptics of the company find it hard to avoid using the company's services.

The sneaky thing about it is that the biggest Google critics I know still use a Google email address. [...] I'd say I was critical of Google, yet I still use their products.

\subsection{Impact on independence}

\section{The notion of partnership}

Google describes its relationship with the media as a "partnership," and likes to call media companies partners in its public communications. In interviews with us, respondents are frequently sceptical about this term. Rejecting the notion of a "partnership" with shared objectives, many of the journalists and publishing managers we spoke to prefer to speak of a purely business relationship [11, J4, J8, P8, P9, P10], criticise the term as euphemistic [J6, J10, $\left.P_{12}\right]$, or voice other objections to its use [J3, J7, J10, J11, P6].

They're not partners. The word itself is enough to get me going. At the end of the day, it's just $P R$. But they're not partners.
Partnerships work when people have common objectives. And there are times when that's true. There are, however, also many times when it isn't.

[P6]

It's no partnership. What it is, clearly, is a dependent relationship, and you have to accept it. [P12]

If they also had the status of publisher, with all the rights, obligations, and responsibilities that that entails, then the term would be justified. Otherwise, you'd have to say, Google is an internet company and, to me at least, not a media organisation in the usual sense. That's why I find the term a bit of a euphemism. [J10]

Statements from the interviews relating to economic relationships with Google are characterised by a certain ambivalence. Several respondents emphasise that Google is both a business partner and a competitor. The word "frenemy" to describe the corporation, a portmanteau of "friend" and "enemy," comes up in five interviews [ $\left.\mathrm{P}_{10}, \mathrm{P}_{11}, \mathrm{P}_{13}, \mathrm{~J}, \mathrm{~J}, \mathrm{~J}\right]$. The digital manager of a large national media company describes it as an "ambivalent relationship":

We're all interested in providing good journalism on the internet, and yet we're depending on sales revenues for our sites, which does put us in some competition with Google. So yes, it's a kind of partnership: together we try to reap the rewards of technology. But, on the other hand, we're also competitors.

[P11] 
Google as a threat to economic independence Several interviewees see the dangers, at least in the longer term, of a potential dependence on Google if technical requirements make the corporation an indispensable business partner.

In this area, yes, Google does try to make itself the onlyoption. And the more Google encroaches on these things, increasing dependence, so to speak, the greater the risk that the media will have nowhere else to turn.

I think there is an inherent tendency for platforms to keep getting bigger. And getting bigger often means providing an all-encompassing service so users can't or don't want to leave any more. And that's certainly a risk, but if we're being honest, it's going to happen whatever we do. We can't stop it anyway. [ [P10]

The latter interviewee, a manager at a large German media organisation, does, however, say that economic dependence is not yet today's reality:

We will never make business decisions relating to Google dependent on us having received funding from Google. We did receive a grant. Then we stopped using Google Analytics as our analytics tool. And Google didn't bat an eyelid or ever really complain about us dropping it, because that's not the relationship, that's not how they roll as business partners. At the end of the day, it's too linear a way of thinking about how relationships work.

[P10]
Several respondents are of the opinion that any business relationship with Google should be subject to clear limits. Three interviewees [P6, P8, P9] stress the importance of maintaining an independent platform to deliver their content. "You'd never stop publishing on your own site just so you could publish elsewhere," says the representative of a large publishing house [P8]. They see smaller competitors as particularly at risk of a dependent relationship:

With advertising customers, too, it's not a good idea to be too dependent on just one. It's a danger when small publishers are too dependent on one ad customer. Of course, the publisher will think twice: 'Well, should I run this exposé on my local advertising partner or not? If I do, they might stop placing ads with us. Big companies, fortunately, don't have this problem. [...] If you're dependent on a large company in some other way, that's also a danger. If they then say, I can't watch this any more, to tell you the truth, so we're going to cancel our service contract. These are all things that can happen. [P8]

Another representative of a large press publisher sees Google's dominance producing a potential dependence in the long term, but thinks it would be counterproductive for publishing houses to keep fighting the corporation:

I wouldn't say that everything's just fine. Not now, and not in the future. Google still has a lot of power in the market and can quickly change things, which might make life difficult for us. 
But not talking to each other in this situation is not an option.

A publishing manager who was involved in decisions concerning the Digital News Innovation Fund sees the situation in a more positive light:

I'd say that press publishers have become more independent because we have new ways to raise funds. We have made some progress in enabling a certain degree of independence, or at least financial viability. There are now more companies who have gone down the path of paid content online or turned to other new revenue sources who maybe wouldn't have, or not to the same extent. Who knows whether it'll work out in the long term? I do think, though, that it's had an effect.

\section{Impacts on day-to-day journalism}

One source of tension in the relationship between media companies and Google is how the search engine actually works. As set out above, many newsrooms devote considerable resources to search engine optimisation (SEO), adjusting their content to match Google's search algorithms. SEO is particularly relevant to services that aim to achieve maximum reach and are mainly funded by advertising. The editor of a high-circulation specialist magazine puts it like this:

It has to be said, unfortunately, that articles are no longer written with the reader clearly in mind. Instead, they're written to be as 'friendly' as possible for Google's algorithms. [...] It's a very dangerous trend, because at some point you have to ask yourself whom you're actually writing articles and doing journalism for. Is it for readers, for people who want to know more? Or am I doing it for an algorithm? I worry that we've already reached the point where we have to say, we're doing it for an algorithm. [J9]

Several interviews touch on surprising or puzzling changes to the search algorithms and their effects [ $\left.\mathrm{P}_{1}, \mathrm{P}_{2}, \mathrm{P}_{3}, \mathrm{P}_{7}, \mathrm{P}_{11}, \mathrm{~J}_{2}\right]$. The digital manager at a large national publisher describes it as an issue on which Google is not particularly willing to provide information:

If I could make a wish - we quickly reach the limits of [Google's; authors' note] willingness to communicate - it would be more transparency regarding how search results change when Google makes it major updates. It's still a complete mystery to us.

Another publishing manager describes changes to Google's search algorithms and the drop in visitor numbers that follows as a "punishment". They note with regret that Google, despite a "good partnership," does not give the publisher the chance to react in good time [P11].

Some journalists say they would not use Google products, or certainly consider not using them, when researching sensitive issues. One of the respondents, for example, states that their newsroom "avoids Google wherever possible" when doing research: 
Firstly, because when we're working on relevant projects, for example articles we want to publish, we don't trust Google, and secondly, quite simply, because we mention persons and maybe contacts, and we would never do it for privacy reasons.

Two further interviewees say they personally do not like to use Google products, at least when reporting on the corporation:

Let's say I need to research something that concerns Google. In that case, I definitely wouldn't use anything from Google to do so. But that's obvious. On the other hand, when I'm researching something that has nothing to do with Google, I wouldn't have such a problem using Google.

On lots of research, I do ask myself whether it's smart to be using this software. I haven't had the pleasure of doing investigative research that would seriously ruffle some feathers at Google, but if I did, I'd be sure not to take all my notes using Google Docs. I wouldn't be so stupid; l'd find an alternative. It's always there at the back of my mind.

\subsection{Interim summary: Google services are frequently essential}

Returning to the research question regarding the extent to which Google services and products are used, it may be stated that, overall, they may be considered essential to day-to-day journalism work. As set out above, the compa- ny has become a key element in the technical infrastructure of the news media.

From an economic standpoint, Google is important to publishers in several different ways. The corporation's products are used to produce, to disseminate, and to monetise news content and to protect and secure the websites on which it is hosted. Google Search and Google News are instrumental in driving traffic to the media companies' sites. The company's products are often used in the creation and evaluation of content, whether that be Google Analytics for measuring visitor flows, web hosting, or bespoke publishing services from Google. Google is also an important partner in the advertising market, providing media organisations with business worth billions through its Google Ad Network and Google Play app store. And finally, Google is also considered a competitor by a number of publishers, for example in the online classified ad market.

Concerning the question of independence at an individual level, some journalists worry about using Google products when doing research on particularly sensitive issues or on subjects relating to the corporation itself. In cases like these, the infrastructure of Google products otherwise used on a daily basis is swapped for services that are considered more trustworthy. This deliberate avoidance of Google products reveals that the company, at least in some specific cases, is seen as an actor whose infrastructure cannot be seen as neutral.

When it comes to independence at editorial level, the interviews show that Google's decisions may directly influence the nuts and 
bolts of news content in the light of the almost completely widespread practice of search engine optimisation. In this context, one journalist openly admits that they consciously optimise articles while writing to make them easier to find. That, they say, makes them feel they are now writing for algorithms, not readers.

At the publishing level, the corporation also directly influences revenues. Most of the media companies we spoke to use some form of monetisation strategy with Google advertising products; a few news media organisations are also already using the Subscribe with Google service. According to several interviewees, changes to the search algorithm may result in sharp economic losses if the visitors they need for ad monetisation can no longer find them.

Even if Google does describe publishers as partners, the majority of respondents reject this notion. Partnership implies equality, they argue, but relationships with Google are more about dependence. At the present time, however, hardly any of them believe there is a general technical and economic dependence on the corporation. Be that as it may, the ubiquity of the company's products and services raises the question, at least in the longer term, of infrastructural independence from Google. 


\section{Strategies to preserve independence}

Most of the interviews with digital journalists and managers also touched on the subject of potential ways to prevent Google's funding from interfering in editorial independence. Although the majority were unable to imagine how this might be possible, it may still be helpful for further research to summarise the actions that have or may conceivably be taken. Before summarising the findings of the study in Chapter 9, these strategies will be briefly set out below.

\subsection{Individual and political strategies}

\section{Organisational strategies}

Some of the interviewees state that measures already in place to ensure that newsrooms can work without influence are sufficient for their relationships with Google. The manager of a large national media organisation notes that, in economic terms, Google is a partner like any other:

We've often worked on very interesting projects with other companies. All down the line. But always taking care not to become dependent, either politically or economically. [...] It's interesting that people only ask us this when we work with Google. Microsoft runs all of our in-house office and cloud architecture. Does Microsoft have any influence on what we write? of course not. And no-one would ever think of asking that question. It's the same with Adobe, another major partner. Or, if we look to the analogue world, our paper makers. Of course we report on issues with recycled paper and deforestation.

[P10]
In this respect, the head of a regional publisher adopts a particular stance within the group of publishing managers [ $\left.\mathrm{P}_{14}\right]$. They say that the separation of publishers' and newsrooms' interests is essentially inadequate and see a "conflict of interest" when Google is both the subject of media coverage and its sponsor. This conflict cannot be resolved by setting up protections, they add, but requires legislation on media funding.

As Brecht said, grub first, then ethics. I think this is a very clear regulatory issue. The regulator needs to lay down rules, and these rules must be adhered to.

[P14]

When asked about protections from Google's influence, the interviewees predominantly point to the separation of editor and publisher roles $\left[P_{2}, P_{10}, P_{11}, P_{12}, J_{1}, J_{5}, J 8\right]$ as a guarantee of media independence.

We would never let Google meddle in our editorial reporting. Or even tolerate them trying to exert influence. From our point of view, it wouldn't be helpful, anyway. Credibility is our most precious asset. I don't think that we'd install safeguards, but we just wouldn't do projects where we sensed that they might impinge on our editorial independence. [P11]

The relatively recent model of editorial development teams is an interesting phenomenon in the present context, with some interviewees stressing that the development of new technologies for journalism demands the involvement of many different internal actors. 
In my experience, the journalists who write lengthy articles and set the tone for the paper, on the one hand, and those in the editorial development teams who literally benefit from the money - their job is financed by it, for example - are two completely different categories in the world of journalism. In other words, the development people never actually write about it.

As this study has shown, some editorial staff are, however, involved in technology projects (see Chapter 5.2), and even took a leading role at one media organisation. One journalist, who writes for a smaller media organisation, reports that editorial staff involved in a DNIfunded project continue to write about Google:

It's not as if the people who are involved in the project, whether directly or on the margins, have suddenly stopped reporting on Google. They do still write about Google. And I'm confident they can stay objective. There's no institutional guarantee that this is the case, however. [J7]

\section{Individual strategies}

Two interviewees are of the opinion that binding ethical guidelines may be one way to prevent unwanted interference, for example a code of conduct, an editorial statute, or journalist handbooks [P2, P7].

Some journalists claim that they already endeavour to counteract any influence or even the suggestion of such influence, with one reporting that they turned down the offer of a board position at an industry association on discovering that it was funded by Google [ $\left.\mathrm{P}_{3}\right]$. Other colleagues state that, at the very least, they would pay to attend Google events other than press conferences themselves. This does not always work out in practice, however, as the editor of an IT industry magazine admits [J9].

\section{Systemic strategies}

Three respondents cite Google's funding transparency as a necessary prerequisite to preventing undue influence $\left[\mathrm{P}_{1}, \mathrm{P}_{3}, \mathrm{P}_{7}\right]$. Two of them, however, work at media organisations that refused to disclose the specific sums of their DNI grants.

One journalist points to media journalism as a site of self-reflection and self-control, a field that can draw attention to potential conflicts of interest in the industry's self-regulation practices.

I think that critical media journalism is the way to go. If [media journalist Stefan; authors' note] Niggemeier and his cohorts continue to look over our shoulders and write some big article about what money is or could be changing hands when we publish a more uncritical report on Google, then that's a sufficient safeguard. Especially as I don't know what kind of internal safeguards could help. I really can't think of anything. So what are we supposed to do? Anything that involved safety precautions [in which potential conflicts of interest in the newsroom were investigated by outsiders; authors' note] would of course also involve a restriction 
of editorial secrecy and our editorial processes. I feel that's more dangerous than what is currently more the theoretical possibility of influence.

[j1]

\section{Political strategies}

When asked, several interviewees say that the issues raised by the growing dominance of Google and other digital companies cannot be solved by publishers alone. One representative from a public service media organisation passes on the question of the possible regulation of digital companies to politicians:

I believe that we, as societies, need a discussion [...] of how we want to deal with these platforms. What powers we do or do not want to give them. And how much of our data security we're willing to give up for the sake of convenience. This, in part, is a deficit in traditional journalism. These topics are considered too complex and too remote to really address. If I wanted to see regulation, then it would be as the result of a robust social discussion of the issue.

One respondent draws a connection between Google's funding initiatives and regulatory fears:

All the tech firms are under enormous political pressure. There's even now talk of breaking them up. Then there's the mountain of regulatory projects, all of which are directed at the corporations. And the journalists are still the public's eyes and ears. Tech companies would be stupid not to care about them or not to maintain understanding or some kind of dialogue with journalists. This they must do.

When asked to name specific regulatory steps, the interviewed publishing managers give only vague answers, but one perceived issue comes up again and again: Google's market power [P8, P10, P14]. Six interviewees - regardless of whether or not they express a view themselves - cite the possible reform of cartel and competition law in relation to the question of available regulatory options $\left[\mathrm{P}_{2}, \mathrm{P}_{4}, \mathrm{P}_{4}, \mathrm{P}_{9}\right.$, P10, P13].

\subsection{Interim summary: scant (institutionalised) protections against conflicts of interest}

The discussions relating to protections against Google's influence reveal that little thought has to date been given specifically to Google's "special relationship" with the German media.

As set out above, the authors of the study found no attempts by Google to influence media content at either the individual or editorial levels. Our conversations, however, brought to light at least one case in which journalists who were directly involved in a project funded by Google also report on Google, thus setting up a potential conflict of interest. Further discussion suggests that some managers are fully assured of their editorial independence and believe they would be able to resolve any potential issues as they arose. 
As becomes clear from research on foundation journalism, the awarding of funds by foundations - or corporations such as Google and Facebook - presently lacks established safeguards to ensure that editorial work is separated from the interests of financial backers. The prime model here would be the traditional separation of editorial and advertising departments. This is reflected in the interviews conducted for this study. Editorial independence is harder to maintain when given no-strings grants from corporations or foundations than is the case with advertising revenues, as the grants are usually directed at specific projects. The sponsor therefore directly influences how the funds are utilised.

In order to avoid conflicts of interest, some of the respondents cite external transparency and ethical guidelines, for example in the form of a code of conduct or editorial statutes, as a solution. Another option might be a voluntary commitment by those involved in funded projects not to report on the company providing funding. It is, however, uncertain whether these specific actions will actually be adopted. One of the interviewees also raises the possibility of an independent auditing body, which would examine the funded projects and their management from a outside perspective. At the same time, this interviewee maintains that an audit of this type could limit editorial secrecy or editorial processes, which would be highly undesirable. Another interviewee, however, points out that funding within the Google News Initiative cannot be understood using the existing categories of influence in the Press Code. This applies not only to undesired consequences of the data company's various financial grants but also and especially to its aim of becoming the infrastructure operator for online journalism.

It is noteworthy that several respondents desire a political response to the growing role of technology corporations such as Google. Ideas about what this response should be, however, remain extremely vague. Overall, the answers make clear that there is currently a void in the space where journalism should be protecting itself against the influence of Google. 


\section{Summary and outlook}

This study examines the relationship between the German news media and the tech corporation Google. Since 2015 at the latest, the company has funded the European industry to the tune of several hundred million euros. At the same time, Google is both a technology and business partner to many publishers, as well as an economic competitor. There is therefore a certain tension between Google's roles as a sponsor, partner, competitor, and subject of reporting. One key aim of this study was to investigate the impacts of these ties on the economic and reporting independence of the media.

Google's funding of the media must be seen in the light of two related developments: the economic crisis facing many news media organisations, and the growing role of technology companies and their founders within the media world. The study initially sets out how the news media have become a popular investment within the technology industry. With advertising revenues collapsing, this change threatens to destabilise the news industry's years-long efforts to balance their reporting and economic interests. A critical light is shone on the small number of scholarly works that address the relationships between press publishers and corporations such as Google and Facebook. These works suggest a lack of viable approaches to isolating newsrooms from the interests of financial backers on the traditional model of separate publisher and editor roles.

The present study draws on a range of sources and methods to shed light on Google's complex relationship with the news media. It uses a data analysis of over 600 media projects funded by Google in Europe and 25 interviews with German publishing managers and digital journalists. A written survey of 22 German media companies provides further insights into their day-to-day use of Google products.

\subsection{Summary of findings}

The first research question looked at the context in which Google's media funding programme came about. The study shows that the data giant's rise to become a patron of the media began in France, where, responding to political pressure, it set up a 60-million-euro fund to support press publishers' innovation projects in 2013. The French fund was the blueprint for the Digital News Initiative (DNI) that Google launched throughout Europe in 2015 and whose core element was the 150-million-euros Digital News Innovation Fund that the company used to promote innovation projects from 2015 to 2019. Examining the political context of these funding programmes reveals that Google's initiatives consistently came about in response to growing political pressure, which the company's managers describe as a “wakeup call" to the corporation. One key issue is the debate surrounding the introduction of a "Google tax" and an ancillary copyright law. Using publicly accessible sources, newspaper articles, press releases, and discussions with industry representatives and Google, the present study sets out how the French Fund and the European DNI became a global undertaking from 2018: the 300-million-dollar Google News Initiative (GNI). 
The second research question posed by this study addresses the distribution of money from the DNI Fund and the beneficiaries of that money in Germany. The data analysis of Google's European project grants initially shows that the money was not disbursed equally but instead reveals a number of disparities: the typical beneficiary of a DNI grant was an established, for-profit, western European publisher. Non-profit media and journalism start-ups were not the focus of funding. Across Europe, some three quarters of the funding millions went to commercial media organisations, the largest share - 21.5 million euros - to Germany. Only four of the 28 large projects to receive funding of more than 300,000 euros in Germany were at regional publishers. At the other end of the spectrum are major publishing empires such as Dieter von Holtzbrinck Medien, Funke Mediengruppe, and Gruner + Jahr, each of whom received between 3 and 10 million euros. More precise figures cannot be provided, since neither Google nor the majority of recipients espouse transparency regarding specific funding amounts. Of the 10 biggest beneficiaries in Germany, only Der Spiegel was happy to provide specific figures. It received some 1.5 million euros; the authors estimate that Google awarded a similar sum to the Frankfurter Allgemeine Zeitung. Overall, the data analysis suggests that Google's funding of the media industry is guided by existing economic structures and probably even works to reinforce them: the rich get richer.

At the same time, the interviews conducted for the study clearly reveal that Google's grants are plugging an urgent financing shortfall for technological development in the industry. Many publishing managers say that their innovation projects would have been impossible to accommodate without DNI funds. One media manager sees Google's initiative as giving the industry a much-needed chance to "catch up," while a journalist describes it as "development aid".

The all-important (fifth) research question regarding the impact of Google's involvement on press independence reveals a complex picture in terms of DNI funding: there is no indication from the interviews that Google may have misused its funding programme to directly influence media coverage in Germany. Nevertheless, interviewed journalists rate this funding as a threat to the independence of their profession. The traditional separation of editor and publisher roles is becoming blurred in the context of technology development projects: creating innovation that benefits journalism frequently requires close coordination with the newsroom. In one case, journalists who report on Google were actually in charge of the project financed by Google. Several journalists also express concerns about compromising ties and potential self-censorship - especially where Google provides large sums of money or multiple grants to one organisation.

This impression is reinforced by the findings relating to Google-funded industry events, fellowships, and training programmes, which the third research question of this study addressed. It is shown that Google's sponsorship has made it a platform for industry debate it- 
self, while giving young journalists a step up on the career ladder. There is barely an industry event in Germany and Europe that takes place without the involvement of the data corporation. In Germany alone, the company has also sponsored 50 fellowships, giving students of journalism the chance to spend time working at leading media organisations such as the Frankfurter Allgemeine Zeitung, Der Spiegel, and Zeit Online. This not only gives Google a seat at the table during industry discussions; it is also defining a generation of budding media professionals.

The fourth research question looked at the technology and economic ties that exist between media companies and Google. Discussions with publishing managers and journalists reveal an ambivalent relationship with the data giant. The results of the written survey make clear that none of the media companies asked can fully dispense with Google products. The corporation and its services are not just important for digital audience acquisition; they also play a part in newsroom workflows and the financing of media companies through advertising. Of 22 of the media surveyed by the study's authors, 18 use Google products such as Analytics to understand visitor flows; 15 use the Google advertising network to monetise their content. By contrast, the interviews also show that many press publishers are sceptics when it comes to the Subscribe with Google service and fear competition from the corporation in the classified ads sector. While Google describes publishers as "partners," a term many interviewees consider controversial, its actions paint it more as a "frenemy" - a portmanteau of "friend" and "enemy".

With regard to the protections that news media have or may yet set up to prevent any threat to press independence from their ever-closer ties to Google, the findings are unambiguous. The industry does not yet appear to have considered ways to emancipate itself from its obliging sponsor and technology partner. Affected publishers, newsrooms, and individuals are evidently little concerned with possible protections; instead, they rely on established approaches such as the separation of editor and publisher roles, refer to existing ethics guidelines, or seek out ad hoc solutions.

\subsection{Six hypotheses}

To conclude this investigation, the following sets out six hypotheses on the relationship between Google and the media industry.

\section{Google's media funding is a strategic instru-} ment serving the corporation's interests.

Even though Google's diverse media funding is now an often unquestioningly accepted part of the new normal in the industry, its involvement in journalism, seven years after the establishment of the first funding programme, still eludes rigorous inquiry. Managers at the company deny it is a means to embed its products within the media. At the same time, though, Google is reluctant to use terms such as philanthropy. But if they are neither pure self-interest nor no-strings handouts, then what purpose do Google's news initiatives serve? 
This study reveals the political pressure that compelled Google to develop the idea of funding the media in France. In the words of the manager responsible for the programme, it was designed to dispel "misunderstandings" between the corporation and the media industry. The news initiatives, then, clearly resemble a large-scale public relations exercise.

Whether this form of chequebook diplomacy has always been a success is a matter of debate - the corporation ultimately lost the political battle surrounding an ancillary copyright law for press publishers in Europe. But the surveys conducted for this study also show that Google has grown its standing with the industry through its grants and efforts to engage in dialogue.

Whatever else may be the case, Google's funding of journalism took on a different hue when the initiative went global in 2018. Whereas the French and pan-European DNI Fund primarily involved direct payments to press publishers, under the Google News Initiative only 30 million dollars, a fraction of the 300-million-euro budget, is provided to fund independent innovation projects at news media organisations. The GNI is far more directly geared towards Google's own interests than its predecessor, for example in the financing of new, high-quality YouTube formats or the optimisation of publisher's offers using the corporation's products and services.

The grants serve to tie media organisations more closely to Google's product ecosystem. The corporation now plays a significant role in the production, distribution, and monetisation of news, opening up the prospect of Google becoming the dominant "operating system" for digital journalism. Google's services have long been essential to the digital media. One interviewee rightly draws a parallel with the idea of platform capitalism: whoever provides infrastructure can exert an influence - especially if at some point they should become the sole provider.

\section{Google's money raises concerns among journalists of compromising ties.}

Google's new approach to funding the media threatens to upset the balance of press and economic interests, not least because of the difficulties in quantifying it: there is little reassurance in the fact that none of the interviews revealed signs that the company has attempted to or successfully exerted any direct editorial influence on the media organisations it supports. On the contrary, Google's millions for the news industry are by no means without consequence, with interviewed journalists expressing concerns about compromising ties and self-censorship.

This is especially true in the case of repeat or particularly high-value grants. This point is particularly important, given that the company not only continued its journalism funding programme following the ending of the European News Initiative in 2019 but has actually now rolled it out worldwide: the millions it provides are becoming a fixed element in the financing of technical advances on which media companies are increasingly dependent in their business development plans. The risk of self-censor- 
ship to avoid upsetting a key funding partner is likely to grow the more Google's funding becomes an established part of the ecosystem, practically indispensable for financing technological developments.

Compounding the problem is the fact that the digital giant, in addition to its media funding, has unleashed a kind of charm offensive: Google's conferences, free training courses for journalists, and fellowships for up-and-coming young journalists all help to showcase the company as a benevolent patron of journalism, but also as a powerful ally of publishers.

\section{Google's funding is worsening economic disparities among media companies.}

Google's project grants serve to reinforce existing economic structures throughout the media landscape. More than two thirds of its funds go to commercial publishers, many of which are old, established companies in western Europe. In Germany, journalism start-ups and regional publishers hardly benefit at all from the company's cash injections. Google is thus helping to decide who wins the battle for survival in the beleaguered media market. Its money helps publishers to catch up in the race to innovate and see off challenges from new competitors.

By contrast, there is no evidence to suggest that the DNI Fund is oriented mainly towards the common good - after all, financially weaker media organisations or non-profit journalists receive substantially fewer grants than their established for-profit rivals. Nor does the DNI fundhelp to close gaps in press coverage throughout Central and Eastern Europe to help bring about greater balance in European public life. On the contrary, existing disparities are widening.

Some start-ups do receive money from Google, but the DNI fund is clearly geared toward benefiting Google's former political opponents. Overall, then, the corporation is making a negative contribution to the development of media pluralism in Europe, as it primarily works to consolidate the market power of established publishers.

\section{The media industry is losing its powers of} self-reflection through Google's grants for research and conferences.

With its own events such as Newsgeist and its sponsorship of numerous conferences, Google supports many important platforms for industry debate. As interviewees questioned for this study stress, Google is in some cases the sole guarantor of regular exchanges between publishers. At the same time, the data corporation funds training organisations such as the European Journalism Centre and journalism research.

As commendable as the objectives of the funded institutions may be, accepting this money nevertheless works to constrain critical debate on the role of the sponsor in the industry: here, again, Google is positioning itself as a platform for industry discussion and community building. But a seat at the table takes the focus off yourself. A journalist who has just spoken to Google about innovation in journalism at a conference might feel less inclined to push for an investigation into the company's 
tax avoidance practices. With its strategic funding of discussion platforms at conferences, its promotion of young journalists, and its academic research, Google is restricting selfreflection within the industry.

\section{Google is trying to become the dominant} technology platform for the news ecosystem.

Today, Google is already subtly setting limits to the independence of the news media. The length of headlines in media articles, the length of the articles themselves - the corporation is already influencing these things with its incentive system of "search engine optimisation". Depending on the configuration of its search algorithm, the corporation decides which articles can be easily found from outside the news websites.

These infrastructural dependencies increase as Google products and services become the "operating system of journalism," a "JournalismOS". As shown in the present study, no publisher today can survive without the use of services such as Google Analytics or the Google advertising network. Google is constantly creating new tools for publishers, such as Subscribe with Google, thus creating dependencies even beyond its dominant position in the digital advertising market.

The risk that this "infrastructural monopoly" poses becomes clear from the history of the news media - whoever sets the conditions for producing, disseminating, and marketing information also has considerable leverage when it comes to content. The attempts by Google to influence the political positions of publishers on issues such as copyright law through its funding provide an indication of this situation. As it becomes increasingly dominant in the digital news business, Google's political voice is only likely to grow louder.

\section{Funding must be transparent; alternatives to Google money are needed.}

The study shows that the firewall between newsrooms and publishers is crumbling because of their need to cooperate on technology projects. New standards and mechanisms are required to bolster it in the face of ongoing pressure to innovate and technology advances in newsrooms. Further research that builds on this study is needed to explore how this might be done.

A clear minimum requirement to help rule out even the suspicion of undue influence is complete transparency regarding the project funding amounts, both from Google and the recipients of the money. The digital giant should disclose the exact sums paid out to media organisation in a database, and the media themselves should be open about their funds and business relationship with Google. Only this would allow us to fully understand the extent of the platform-publisher relationship.

At the end of the day, what is needed is a public debate: what does it say about the situation in journalism when it feels compelled to accept the help of a corporation that is at once a business partner, a competitor, and the subject of reporting? It seems just as ethically dubious as a situation in which publishers, employing the same arguments, were to finance their 
technology developments through car companies, their training courses through sports associations, or their conferences through the pharma industry.

Google is plugging a yawning financial gap with its funding programme. The challenge facing the news media in a democratic society is to find alternatives that are less likely to endanger their independence. The authors of this study therefore believe that the European and German debate on public innovation funding for the media must continue.

The present study is exploratory in nature and offers a number of jumping-off points for further research. One important issue to help understand Google's role in the industry is the transformation in how the corporation has been covered in the media over recent years. Also important is a closer look at the non-European News Initiative, a more in-depth investigation of Google's promotion of young journalists, and the corporation's influence on academic journalism research. In addition, a systematic investigation of the technology and economic ties between the news media and Google would also be of relevance to the research topic, for example by providing an estimate of the Google advertising network's financial share of corporate revenues. Only a precise, objective examination of Google's commitment to and influence on the news media will allow systematic steps to be taken to maintain the industry's independence in the long term. 


\section{Appendix}

Bibliography....................................................................................................... 97

Appendix A: Written responses from Google .......................................................107

Appendix B: Interview with Madhav Chinnappa,

Ludovic Blecher and Ralf Bremer....................................................................111

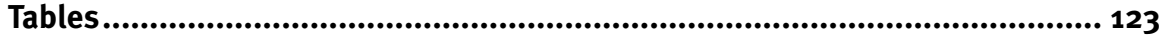

Notes on the authors............................................................................................ 123

\section{Online appendix}

The online appendix to the study contains further materials for viewing and free download. Go to www.otto-brenner-stiftung.de to find

- the list of media organisations contacted for the survey on product use, as well as the questionnaire and the accompanying cover letter (see Chapter 3.2),

- a list of all projects funded by the DNI and the (German and English) reply from the London School of Economics to an enquiry sent by the authors (see Chapter 3.3),

- the two interview guidelines for digital journalists and digital managers (see Chapter 3.4),

a the original transcript of the interview with Google managers and the written questions for Google (see Chapter 3.5),

- the list of all Google fellowships in Germany (to July 2020, see Chapter 6.1). 


\section{Bibliography}

John Baker, “A home-grown news site for Peterborough”, https://www.blog.google/outreach-initiatives/ google-news-initiative/home-grown-news-site-peterborough/ (14 February 2020), retrieved on 28 March 2020.

BDZV, “Leistungsschutzrecht für die Presse ist überfällig”, https://www.bdzv.de/nachrichten-und-service/ presse/pressemitteilungen/artikel/detail/leistungsschutzrecht_fuer_die_presse_ist_ueberfaellig-1/ (7 May 2009), retrieved on 27 March 2020.

BDZV, “Zeitungen und ihre Leser in Stichworten 2019”, https://www.bdzv.de/maerkte-und-daten/ marktdaten/zeitungen-in-zahlen-und-daten/ (2019), retrieved on 1 May 2020.

BDZV, “Rubriken-Portale deutscher Zeitungen”, https://www.bdzv.de/maerkte-und-daten/digitales/ rubrikenmarkt/ (2020), retrieved on 10 April 2020.

Klaus Beck, Das Mediensystem Deutschlands (Wiesbaden: Springer VS, 2012).

Charlie Beckett, “New powers, new responsibilities. A global survey of journalism and artificial intelligence”, https://blogs.lse.ac.uk/polis/2019/11/18/new-powers-new-responsibilities/ (18 November 2019), retrieved on 28 March 2020.

Nicolas Becquet, “Freiwillig in die Abhängigkeit: Facebook und die Medien”, https://de.ejo-online.eu/ qualitaet-ethik/freiwillig-in-die-abhaengigkeit-facebook-und-die-medien (22 November 2017), retrieved on 28 March 2020.

Emily Bell, “Do technology companies care about journalism?”, https://www.cjr.org/tow_center/googlefacebook-journalism-influence.php (27 March 2019), retrieved on 10 April 2020.

Brad Bender, "A new licensing program to support the news industry”, https://www.blog.google/outreachinitiatives/google-news-initiative/licensing-program-support-news-industry (25 June 2020), retrieved on 30 June 2020.

Rodney Benson, “Can foundations solve the journalism crisis?”, in Journalism, https://journals.sagepub. com/doi/abs/10.1177/1464884917724612 (31 August 2018), retrieved on 27 March 2020.

Oliver Bidlo, “Eine kurze Geschichte der Medien als Vierte Gewalt”, Tat-Ort Medien: Die Medien als Akteure und unterhaltsame Aktivierer, ed. Oliver Bidlo, Carina J. Englert, Jo Reichertz (Wiesbaden: Springer VS, 2012), 151-168.

Ludovic Blecher, “Digital News Innovation Fund: three years in, and 662 total projects supported”, https:// www.blog.google/around-the-globe/google-europe/digital-news-innovation-fund-three-years-and-662total-projects-supported/ (21 March 2019), retrieved on 28 March 2020.

Ludovic Blecher, "Sparking new ideas in news with global Innovation Challenges", https://blog.google/ outreach-initiatives/google-news-initiative/global-innovation-challenge/ (26 March 2019, retrieved on 28 March 2020.

Daniel Bouhs, “Ist Hamburg Media School zu nah an Facebook?”, https://www.ndr.de/nachrichten/netzwelt/ Ist-Hamburg-Media-School-zu-nah-an-Facebook,hamburgmediaschool102.html (16 October 2018), retrieved on 29 March 2020.

Hans-Bernd Brosius, Alexander Haas, and Friederike Koschel, Methoden der empirischen Kommunikationsforschung. Eine Einführung (7th ed.). (Wiesbaden: Springer VS, 2016). 
German Federal Government, “Rede von Bundeskanzlerin Dr. Angela Merkel beim Zeitungskongress des Bundesverbandes Deutscher Zeitungsverleger e.V. am 19. September 2011 in Berlin”, in Bulletin 92-2 (2011), https://www.bundesregierung.de/breg-de/service/bulletin/rede-von-bundeskanzlerin-dr-angelamerkel-802310, retrieved on 27 March 2020.

Christopher Buschow, Catherina Dürrenberg, and Carsten Winter, "Change Management in Tageszeitungsredaktionen”, Medieninnovationen. Wie Medienentwicklungen die Kommunikation in der Gesellschaft verändern, ed. Jens Wolling, Andreas Will, and Christina Schumann (Konstanz: Schriftenreihe der Deutschen Gesellschaft für Publizistik- und Kommunikationswissenschaft, Vol. 38, 2011), 195-210.

Christopher Buschow, Strategische Institutionalisierung durch Medienorganisationen. Der Fall des Leistungsschutzrechtes. (Cologne: Herbert von Halem Verlag, 2012).

Christopher Buschow, Christian Wellbrock, "Money for Nothing and Content for free? Zahlungsbereitschaft für digitale Inhalte”, https://www.medienanstalt-nrw.de/fileadmin/user_upload/lfm-nrw/Foerderung/ Forschung/Zahlunsbereitschaft/LFMNRW_Whitepaper_Zahlungsbereitschaft.pdf (Landesanstalt für Medien NRW, 2019), retrieved on 22 May 2020.

Dell Cameron, Kate Conger, “Google Is Helping the Pentagon Build Al for Drones”, https://gizmodo.com/ google-is-helping-the-pentagon-build-ai-for-drones-1823464533 (3 March 2018), retrieved on 24 May 2020.

Campaign for Accountability, “Google’s Media Takeover”, https://www.techtransparencyproject.org/sites/ default/files/GTP-Media-Takeover.pdf (2019), retrieved on 27 March 2020.

Madhav Chinnappa, “Google DNI e-mail on copyright”, https://cdn.netzpolitik.org/wp-upload/2018/o9/ google-dni-email-on-copyright.pdf (2018), retrieved on 26 April 2020.

Chung-yan Chow, "Alibaba's Jack Ma reveals why he bought the South China Morning Post and what he wants to do with it”, https://www.scmp.com/news/china/society/article/1937256/alibabas-jack-ma-reveals-whyhe-bought-south-china-morning-post (21 April 2016), retrieved on 29 March 2020.

Mark Coddington, “The Wall Becomes a Curtain: Revisiting Journalism's News-Business Boundary”, in Seth C. Lewis, Matt Carlson, Boundaries of Journalism. Professionalism, Practices and Participation. (Abingdonon-Thames et al.: Routledge, 2015).

Valérie Collet, Marie-Catherine Beuth, Paule Gonzalès, “Nicolas Sarkozy stigmatise Google”, https://www. lefigaro.fr/medias/2010/01/08/04002-20100108ARTFIG00006-nicolas-sarkozy-stigmatise-google-.php (8 January 2010), retrieved on 27 March 2020.

Corporate Europe Observatory, “Copyright Directive: how competing big business lobbies drowned out critical voices”, https://corporateeurope.org/en/2018/12/copyright-directive-how-competing-big-business-lobbiesdrowned-out-critical-voices (10 December 2018), retrieved on 22 May 2020.

Corporate Europe Observatory, “Shutting down ePrivacy: lobby bandwagon targets Council”, https:// corporateeurope.org/en/power-lobbies/2018/o6/shutting-down-eprivacy-lobby-bandwagon-targetscouncil (4 June 2018), retrieved on 22 May 2020.

Ingo Dachwitz, “News Initiative: Wohin Googles Millionen für die Medien in Deutschland fließen”, https:// netzpolitik.org/2018/news-initiative-wohin-googles-millionen-fuer-die-medien-in-deutschland-fliessen/ (2018), retrieved on 1 March 2020. 
Ingo Dachwitz, Alexander Fanta, "Wie Europa den Schutz gegen Tracking im Netz aufs Abstellgleis manövriert”, https://netzpolitik.org/2018/wie-europa-den-schutz-gegen-tracking-im-netz-aufs-abstellgleismanoevriert/ (15 October 2018), retrieved on 22 May 2020.

Charles R. Davis, “The Intercept, a billionaire-funded public charity, cuts back”, https://www.cjr.org/ business_of_news/layoffs-the-intercept.php (15 March 2019), retrieved on 29 March 2020.

Deutsche Presseagentur, “Digital Innovation Fonds: Google zahlte in vier Jahren über 20 Millionen Euro an deutsche Medien”, https://meedia.de/2019/03/21/digital-innovation-fonds-google-zahlte-in-vier-jahrenueber-20-millionen-euro-an-deutsche-medien/ (2019), retrieved on 5 April 2020.

Deutscher Presserat, “Pressekodex”, https://www.presserat.de/pressekodex.html, retrieved on 2 January 2020.

LaToya Drake, “Meet the 2018 Google News Initiative Journalism Fellows”, https://www.blog.google/ outreach-initiatives/google-news-initiative/meet-2018-google-news-initiative-journalism-fellows/ (22 June 2018), retrieved on 27 March 2020.

Élysée, “Déclarations conjointes de MM. François Hollande, Président de la République, Eric Schmidt, président de Google, Marc Schwartz, médiateur, et Mme Nathalie Collin, présidente de l’Association de la presse d'information politique et générale, sur l'accord entre Google et la presse française", https://www.elysee.fr/francois-hollande/2013/02/01/declarations-conjointes-de-mm-francois-hollande-president-de-larepublique-eric-schmidt-president-de-google-marc-schwartz-mediateur-et-mme-nathalie-collin-presidentede-lassociation-de-la-presse-dinformation-politique-et-generale-sur-laccord (1 February 2013), retrieved on 27 March 2020.

European Commission, “Antitrust: Kommission verhängt Geldbuße in Höhe von 1,49 Mrd. EUR gegen Google wegen Missbrauchs einer beherrschenden Stellung auf dem Markt für Online-Werbung”, https://ec.europa. eu/commission/presscorner/detail/de/IP_19_1770 (2019), retrieved on 15 July 2020.

Sophie Eyears, “How BBC News Built a More Engaged Audience on Instagram”, https://www.facebook.com/ journalismproject/bbc-news-instagram, (19 December 2019), retrieved on 29 February 2020.

Alexander Fanta, “Citizen Google: Wie ein Konzern den Journalismus dominiert”, https://netzpolitik. org/2018/citizen-google-wie-ein-konzern-den-journalismus-dominiert/ (26 September 2018), retrieved on 27 March 2020.

Alexander Fanta, Ingo Dachwitz, “Die Verlegerverleger: Google, Apple und Facebook wollen die Paywall kapern”, https://netzpolitik.org/2019/die-verlegerverleger-google-apple-und-facebook-wollen-die-paywallkapern/ (18 April 2019), retrieved on 10 April 2020.

Patrick Ferrucci, Jacob L. Nelson, “The New Advertisers. How Foundation Funding Impacts Journalism”, Media and Communications 7(4), 45-55, https://www.cogitatiopress.com/mediaandcommunication/article/ view/2251/2251 (2019), retrieved on 27 March 2020.

Adrienne Fichter, “Wie Google zum Medien-Mäzen wurde”, https://www.republik.ch/2018/10/15/wiegoogle-zum-medien-maezen-wurde (15 October 2018), retrieved on 21 May 2020.

Frederic Filloux, “Google vs. the press: avoiding the lose-lose scenario”, https://mondaynote.com/googlevs-the-press-avoiding-the-lose-lose-scenario-141258e6de33 (20 January 2013), retrieved on 27 March 2020. 
FINP, “Qu'est-ce que le FINP?”, https://web.archive.org/web/20131109092534/http://www.finp.fr/le-fonds (9 November 2013), retrieved on 27 March 2020.

Frederik Fischer, “\#Netzwende: Warum zahlen LeserInnen (nicht) für Journalismus im Netz?”, https:// medium.com/@FrederikFischer/netzwende-warum-zahlen-leserinnen-nicht-f\%C $3 \% B C r$-journalismus-imnetz-7ff43de5ff69 (12 April 2018), retrieved on 22 May 2020.

Richard Fletcher, Paying for News and the Limits of Subscription. Digital News Report. (Oxford: Reuters Institute for the Study of Journalism, 2019), http://www.digitalnewsreport.org/survey/2019/paying-for-newsand-the-limits-of-subscription/, retrieved on 27 March 2020.

Kerry Flynn, "LinkedIn now has a newsroom of 65 journalists. It's hiring more", https://edition.cnn. com/2019/10/23/media/linkedin-journalists/index.html (23 October 2019), retrieved on 29 March 2020.

Craig Forman, “McClatchy and Google partner on an experimental lab for local news”, https://www.blog. google/outreach-initiatives/google-news-initiative/mcclatchy-and-google-partner-experimental-lab-localnews/ (26 March 2019), retrieved on 28 March 2020.

Robert Fortner, “How Ray Suarez Really Caught the Global Health Bug. The Gates Foundation, global health, and the media”, https://archives.cjr.org/the_observatory/how_ray_suarez_really_caught_t.php (7 October 2010), retrieved on 10 April 2020.

FragdenStaat.de, “Auszuwertende Medien für die Kanzlermappe”, https://fragdenstaat.de/anfrage/ auszuwertende-medien-fur-die-kanzlermappe/ (16 August 2019), retrieved on 2 May 2020.

FragdenStaat.de, “Interactions with Google”, https://fragdenstaat.de/projekt/interactions-with-google/ (9 July 2019), retrieved on 2 May 2020.

Lutz Frühbrodt, “Content Marketing. Wie ‘Unternehmensjournalisten’ die öffentliche Meinung beeinflussen”, OBS-Arbeitsheft 86, Frankfurt am Main, 2016), https://www.otto-brenner-stiftung.de/wissenschaftsportal/ informationsseiten-zu-studien/studien-2016/content-marketing/, retrieved on 27 July 2020.

Matthes Garrahan, Mehreen Khan, “Google criticised for push against EU copyright reform”, https://www. ft.com/content/a8031d7a-78ao-11e8-bc55-5odaf11b72od (26 June 2018), retrieved on 26 April 2020.

Gates Foundation, “Awarded Grants”, https://www.gatesfoundation.org/How-We-Work/Quick-Links/ Grants-Database\#q/k=journalism \&page=1 (2020), retrieved on 29 March 2020.

GIJC, “Sponsors”, https://gijc2019.org/sponsors/ (2019), retrieved on 28 March 2020.

Richard Gingras, “GNI Subscriptions Lab expands to Europe to help publishers grow revenue”, https://www. blog.google/around-the-globe/google-europe/gni-subscriptions-lab-expands-europe-help-publishersgrow-revenue/ (12 February 2020), retrieved on 28 March 2020.

Astrid Girardeau, “La pub en ligne doit-elle soutenir la création?”, https://www.liberation.fr/ ecrans/2009/09/29/la-pub-en-ligne-doit-elle-soutenir-la-creation_951171 (29 September 2009), retrieved on 27 March 2020.

Astrid Girardeau, “Google : ‘taxer la publicité en ligne, c’est faire de la France un enfer fiscal numérique”, https://www.liberation.fr/ecrans/2009/o9/29/google-taxer-la-publicite-en-ligne-c-est-faire-de-la-franceun-enfer-fiscal-numerique_948624 (29 September), retrieved on 27 March 2020. 
Anna Goldenberg, “Gottes Werk und Googles Geld”, https://www.falter.at/zeitung/20180926/gottes-werkund-googles-geld/252318386e (26 September 2018), retrieved on 21 May 2020.

Google News Initiative, “Council members”, https://newsinitiative.withgoogle.com/dnifund/participate/ members/ (2016), retrieved on 31 March 2020.

Google News Initiative, “DNI Fund. Rules of Governance”, https://newsinitiative.withgoogle.com/dnifund/ documents/23/DNI-Governance-Rules-02082018.pdf (2 August 2018), retrieved on 2 May 2020.

Google News Initiative, “Courses”, https://newsinitiative.withgoogle.com/training/courses, retrieved on 31 March 2020.

Google News Initiative, “Selected Project”, https://newsinitiative.withgoogle.com/innovation-challenges/ funding/ (2020), retrieved on 28 May 2020.

Andreas Grieß, “'Spiegel’: Holger Friedrich bringt weitere Interessenkonflikte in die 'Berliner Zeitung”, https://www.turi2.de/aktuell/spiegel-holger-friedrich-bringt-weitere-interessenkonflikte-in-die-berlinerzeitung/ (22 November 2019), retrieved on 4 March 2020.

Handelsblatt, “EU plant Urheberrechtsabgabe im Internet”, https://www.handelsblatt.com/politik/ international/schutz-geistigen-eigentums-bis-2016-eu-plant-urheberrechtsabgabe-im-internet/10900130. html (28 October 2014), retrieved on 27 March 2020.

Handelsblatt Media Group, “Handelsblatt Media Group und Google Zukunftswerkstatt werden Bildungspartner-Gemeinsames Programm zur digitalen Weiterbildung in Deutschland”, https://handelsblattgroup.com/ Presse/handelsblatt-media-group-und-google-zukunftswerkstatt-werden-bildungspartner-gemeinsamesprogramm-zur-digitalen-weiterbildung-in-deutschland/ (2019), retrieved on 31 March 2020.

Thomas Hanitzsch, Josef Seethaler, Vinzenz Wyss, Journalismus in Deutschland, Österreich und der Schweiz (Wiesbaden: Springer VS, 2019).

Matthias Heim, “'In eigener Sache’ - Der journalistische Metadiskurs zu Medienvertrauen”, transfer - Kommunikationswissenschaftliche Nachwuchsforschung im Internet 23(4), http://transfer.dgpuk.de/abstracts/ in-eigener-sache-der-journalistische-metadiskurs-zu-medienvertrauen/ (2019), retrieved on 10 May 2020.

Jana Hensel, “Ostdeutscher Albtraum”, https://www.zeit.de/2019/52/holger-silke-friedrich-berlinerzeitung-stasi-vergangenheit-verleger/komplettansicht (11 December 2019), retrieved on 4 March 2020.

Javier C. Hernández, “A Hong Kong Newspaper on a Mission to Promote China’s Soft Power”, https://www. nytimes.com/2018/03/31/world/asia/south-china-morning-post-hong-kong-alibaba.html (31 March 2018), retrieved on 29 March 2020.

Miriam Hoffmeyer, “Googles nächste Attacke”, https://www.sueddeutsche.de/karriere/google-job-suchestellenmarkt-karriere-1.4537916 (31 July 2019), retrieved on 4 March 2020.

Aaron Horvath, Walter W. Powell, “Contributory or Disruptive: Do New Forms of Philanthropy Erode Democracy?", in Philanthropy in Democratic Societies. History, Institutions, Values, ed. Rob Reich, Chiara Cordelli, Lucy Bernholz (Chicago/London: University of Chicago Press, 2016), https://woodypowell.com/wp-content/ uploads/2016/02/Horvath_Powell_ContributoryOrDisruptive_Final.pdf, retrieved on 30 June 2020.

ICFJ, “International Center for Journalists - Past Programs”, https://www.icfj.org/our-work/past (2020), retrieved on 30 June 2020. 
Mathew Ingram, “Here's what happened inside The Markup”, https://www.cjr.org/analysis/the-markup.php (25 March 2019), retrieved on 29 March 2020.

Mathew Ingram, “Facebook says it plans to put \$300M into journalism projects", https://www.cjr.org/ the_new_gatekeepers/facebook-journalism-funding.php (15 January 2019), retrieved on 29 March 2020.

IVW, “IVW Ausweisung Digital-Angebote, Gemessene Nutzungsdaten”, http://ausweisung.ivw-online. $\mathrm{de} /$ index.php? $\mathrm{i}=116 \& \mathrm{mz} \_\mathrm{szm}=202003 \& \mathrm{pis}=0 \& \mathrm{az} \_$filter $=0 \& \mathrm{~kat} 1=0 \& \mathrm{~kat} 2=0 \& \mathrm{~kat} 3=0 \& \mathrm{~kat} 4=0 \& \mathrm{~kat} 5=0 \&$ kat6 $=0 \&$ kat7 $=0 \&$ kat $8=0 \&$ sort $=v g d \&$ suche $=(2020)$, retrieved on 27 February 2020.

Nils Jacobsen, “'Facebook haut seine Partner übers Ohr’: Social Network bezahlt Verlage 2018 nicht mehr für (Live-) Video-Produktion”, https://meedia.de/2017/12/13/facebook-laesst-bezahlte-video-kooperation-mitverlagen-auslaufen/ (13 December 2017), retrieved on 29 March 2020.

Journalism Fellowships in Europe, “Germany”, https://journalismfellowships.eu/country/germany (2020), retrieved on 10 April 2020.

Jacob Kastrenakes, "Elon Musk wanted The Onion; he got Thud", https://www.theverge.com/ 2019/7/2/18701197/elon-musk-thud-satire-startup-onion-launch-failure (2 July 2019), retrieved on 29 March 2020.

Patrick Kingsley, Benjamin Novak, "The Website That Shows How a Free Press Can Die”, https://www. nytimes.com/2018/11/24/world/europe/hungary-viktor-orban-media.html (24 November 2018), retrieved on 28 March 2020.

Rasmus Kleis Nielsen, Sarah Anne Ganter, "Dealing with digital intermediaries: A case study of the relations between publishers and platforms", new media \& society 20(4) (2017), 1600-1617.

https://journals.sagepub.com/doi/pdf/10.1177/1461444817701318, retrieved on 22 May 2020.

Guillaume Klossa, “Toward European Media Sovereignty. An Industrial Media Strategy to leverage Data, Algorithms and Artificial Intelligence”, https://ec.europa.eu/commission/sites/beta-political/files/ guillaume_klossa_report_final.pdf (28 March 2019), retrieved on 19 April 2020.

Katrin Kowark, “Qualitätsjournalismus und Stiftungen. Erfahrungen mit einer Initiative”, in Wissenschaft und Gesellschaft: Ein vertrauensvoller Dialog. Positionen und Perspektiven der Wissenschaftskommunikation heute, ed. Johannes Schnurr and Alexander Mäder (Berlin: Springer, 2020), 87-106.

Siegfried Lamnek, Qualitative Sozialforschung: Lehrbuch (Weinheim: Beltz PVU, 2005).

Corinna Laurer, Guido Keel, “Journalismus zwischen Unabhängigkeit und Einfluss”, in Journalismus in Deutschland, Österreich und der Schweiz, ed. Thomas Hanitzsch, Josef Seethaler, and Vinzenz Wyss (Wiesbaden: Springer VS, 2019), 103-134.

Edmund Lee, "Washington Post Finds Itself in the Middle of the Jeff Bezos Story", https://www.nytimes. com/2019/02/11/business/media/washington-post-jeff-bezos.html (11 February 2019), retrieved on 29 March 2020.

Jing Lee, “Liberating or Constraining? How technology capital is reshaping the media land-scape in China", https://reutersinstitute.politics.ox.ac.uk/sites/default/files/2018-01/Jing\%2oLee\%2opaper.pdf (2018), retrieved on 29 March 2020. 
Frank Lobigs, Christoph Neuberger, “Meinungsmacht im Internet und die Digitalstrategien von Medienunternehmen. Neue Machtverhältnisse trotz expandierender Internet-Geschäfte der traditionellen MassenmedienKonzerne. Gutachten für die Kommission zur Ermittlung der Konzentration im Medienbereich (KEK)”, Schriftenreihe der Landesmedienanstalten, Vol. 51 (Leipzig: Vistas Verlag, 2018).

Claudia Mast, Klaus Spachmann, Katharina Georg, Den Mächtigen auf die Finger schauen. Zur Zukunft von Tageszeitungen in der Region (Baden-Baden, 2019).

Philipp Mayring, Thomas Fenzl, “Qualitative Inhaltsanalyse”, in Handbuch Methoden der empirischen Sozialforschung, ed. Nina Baur and Jörg Blasius (Wiesbaden: Springer Fachmedien 2019), 633-648.

MediaPowerMonitor, “Google Bankrolls Oligarch-Owned Media Group in Hungary”, https://medium.com/ mediapowermonitor/google-bankrolls-oligarch-owned-media-group-in-hungary-8oc1981b7f1c (28 March 2019), retrieved on 28 March 2020.

Christian Meier, “Warum sich ein Ehepaar aus Berlin eine Zeitung kauft”, https://www.welt.de/kultur/ medien/article200440064/Dumont-stoesst-Berliner-Verlag-ab-Ehepaar-aus-Berlin-kauft-Berliner-Zeitung. html (17 September 2019), retrieved on 4 March 2020.

Klaus Meier, Journalistik (3rd ed.) (Konstanz: UVK Verlagsgesellschaft, 2013).

Ali Montag, “Jeff Bezos, Laurene Powell Jobs and now Marc Benioff: Why tech billionaires are buying media companies”, https://www.cnbc.com/2018/09/17/bezos-to-marc-benioff-why-billionaires-are-buying-mediacompanies.html (2018,17 September 2019), retrieved on 29 February 2020.

Efrat Nechushtai, “Could digital platforms capture the media through infrastructure?”, Journalism 19(8) (2017), 1043-1058.

newsgeist.org, “Exploring The Future Of News”, https://www.newsgeist.org/exploring-future-news/, retrieved on 31 March 2020.

News Impact, “Identity \& Inclusion: Local News With Diverse Voices”, https://newsimpact.io/summits/ news-impact-summit-munich, (2019), retrieved on 28 March 2020.

Marvin Oppong, “Ausverkauf der Journalismus? Medienverlage und Lobbyorganisationen als Kooperationspartner”, OBS-Arbeitspapier 21. (Frankfurt am Main), https://www.otto-brenner-stiftung. de/wissenschaftsportal/publikationen/titel/ausverkauf-des-journalismus/aktion/show/obspaec/ Publication/ (2016), retrieved on 27 July 2020.

Pier Luigi Parcu, “New digital threats to media pluralism in the information age”, EUI Working Paper 2019/19, https://cadmus.eui.eu/bitstream/handle/1814/61890/RSCAS\%202019_19.pdf, (2019), retrieved on 19 April 2020.

Sahil Patel, “Facebook plans to stop paying publishers to make news feed videos”, https://digiday.com/ media/facebook-plans-to-stop-paying-publishers-to-make-news-feed-videos/ (13 December 2017), retrieved on 22 May 2020.

Eric Pfanner, “A Clash Across Europe Over the Value of a Click”, https://www.nytimes.com/2012/10/31/ technology/european-newspapers-seeking-a-piece-of-google-ad-revenue.html (30 October 2012), retrieved on 27 March 2020. 
Nicola Pointner, In den Fängen der Ökonomie? Ein kritischer Blick auf die Berichterstattung über Medienunternehmen in der deutschen Tagespresse (Wiesbaden: VS Verlag für Sozialwissenschaften, 2010).

Nushin Rashidian, Pete Brown, Elizabeth Hansen, Emily Bell, Jonathan Albright, Abigail Hartstone, Friend and Foe: The Platform Press at the Heart of Journalism (Tow Center for Digital Journalism at Columbia Journalism School, 2018), https://www.cjr.org/tow_center_reports/the-platform-press-at-the-heart-of-journalism.php, retrieved on 27 March 2020.

Nushin Rashidian, George Tsiveriotis, Pete Brown, Emily Bell, Abigail Hartstone, Platforms and Publishers: The End of an Era. Tow Center for Digital Journalism at Columbia Journalism School, 2019), https://www.cjr. org/tow_center_reports/platforms-and-publishers-end-of-an-era.php, retrieved on 27 March 2020.

Reporters Without Borders, “Rangliste der Pressefreiheit 2020”, https://www.reporter-ohne-grenzen.de/ fileadmin/Redaktion/Downloads/Ranglisten/Rangliste_2020/Rangliste_der_Pressefreiheit_2020_-_RSF. pdf (2020), retrieved on 17 July 2020.

Reuters, “EU has 'serious doubts' about Italy's proposed Web tax”, https://www.reuters.com/article/ italy-webtax/update-1-eu-has-serious-doubts-about-italys-proposed-web-tax-idUSL6NoJY3D020131219 (19 December 2013), retrieved on 27 March 2020.

Reuters, “Italy cancels ‘Google tax’ on web companies”, https://www.reuters.com/article/us-italy-tax/ italy-cancels-google-tax-on-web-companies-idUSBREA1RoWM20140228, (28 February 2014), retrieved on 27 March 2020.

Reuters Institute, “Google and the University of Oxford agree extension in support for Digital News Project to August 2020", https://reutersinstitute.politics.ox.ac.uk/risj-review/google-and-university-oxford-agreeextension-support-digital-news-project-august-2020 (2018), retrieved on 30 June 2020.

Reuters Institute, “Google News Initiative and Oxford University agree extension in support for Digital News Project to August 2023”, https://reutersinstitute.politics.ox.ac.uk/risj-review/google-news-initiative-andoxford-university-agree-extension-support-digital-news (2020), retrieved on 30 April 2020.

Reuters Institute, “Our funders”, https://reutersinstitute.politics.ox.ac.uk/our-funders (2020), retrieved on 24 May 2020.

Jeff John Roberts, “Oracle is Funding a New Anti-Google Group”, https://fortune.com/2016/08/19/googletransparency-project-2/ (19 August 2016), retrieved on 27 March 2020.

Alan Rusbridger, Breaking News. The Remaking of Journalism and Why It Matters Now (Edinburgh: Canongate Books, 2018).

Noam Scheiber, Daisuke Wakabayashi, “Google Hires Firm Known for Anti-Union Efforts”, https://www. nytimes.com/2019/11/20/technology/Google-union-consultant.html (20 November 2019), retrieved on 26 May 2020.

Philipp Schindler, “The Google News Initiative: Building a stronger future for news", https://www.blog. google/outreach-initiatives/google-news-initiative/announcing-google-news-initiative/ (20 March 2018), retrieved on 27 March 2020.

Christine Schmidt, "Why did Google’s Digital News Innovation Fund offer up to $€ 50,000$ to a mouthpiece of Hungary’s authoritarian government?”, https://www.niemanlab.org/2019/o4/why-did-googles-digitalnews-innovation-fund-offer-up-to-e5000o-to-a-mouthpiece-of-hungarys-authoritarian-government/ (3 April 2019), retrieved on 27 March 2020. 
Eric Schmidt, “Google creates €6om Digital Publishing Innovation Fund to support transformative French digital publishing initiatives", https://www.blog.google/outreach-initiatives/google-news-initiative/ google-creates-6om-digital-publishing/ (1 February 2013), retrieved on 27 March 2020.

Thomas Schnedler, "Prekäre Arbeit im Journalismus" (PhD dissertation, University of Hamburg, 2017), https://ediss.sub.uni-hamburg.de/volltexte/2020/10196/pdf/Dissertation.pdf, retrieved on 22 May 2020.

Martin Scott, Mel Bunce, Kate Wright, "Foundation Funding and the Boundaries of Journalism”, Journalism Studies 20(14), 2034-2052, https://www.tandfonline.com/doi/full/10.1080/1461670X.2018.1556321(2019), retrieved on 27 March 2020.

Robert Seamans, Feng Zhu, "Responses to Entry in Multi-Sided Markets: The Impact of Craigslist on Local Newspapers", NET Institute Working Paper 10-11 (2013).

Damien Sharkov, “Google News Quits Spain After Tax Row”, https://www.newsweek.com/google-newsleaves-spain-after-new-tax-row-291030 (11 December 2014), retrieved on 27 March 2020.

Frank X. Shaw, “Teaming up to help journalism thrive in the digital age”, https://blogs.microsoft.com/ blog/2019/01/16/teaming-up-to-help-journalism-thrive-in-the-digital-age/ (16 January 2019), retrieved on 29 March 2020.

Ken Silverstein, “Where Journalism Goes to Die”, https://www.politico.com/magazine/story/2015/02/ ken-silverstein-the-intercept-115586 (27 February 2015), retrieved on 29 March 2020.

Society of Professional Journalists, "SPJ Training Program in association with Google News Initiative", https://www.spj.org/google.asp, (2020), retrieved on 31 March 2020.

Ravi Somaiya, “The New Republic Is Sold”, https://www.nytimes.com/2016/02/27/business/media/thenew-republic-is-sold.html (26 February 2016), retrieved on 29 March 2020.

Spiegel, “Verlage knicken vor Google ein”, https://www.spiegel.de/netzwelt/netzpolitik/leistungsschutzrecht-verlage-erteilen-google-recht-auf-gratisnutzung-a-998774.html (23 October 2014), retrieved on 27 March 2020.

David Streitfeld, “Craig Newmark, Newspaper Villain, Is Working to Save Journalism”, https://www.nytimes. com/2018/10/17/technology/craig-newmark-journalism-gifts.html (17 October 2018), retrieved on 30 June 2020.

Xavier Ternisien, "En conflit avec la presse belge, Google accepte de l'indemniser”, https://www. lemonde.fr/economie/article/2012/12/13/google-indemnise-la-presse-belge-pour-violation-du-droit-dauteur_1805881_3234.html (13 December 2012), retrieved on 27 March 2020.

Adam Thomas, “In Europe, Foundations Invest in News", Predictions for Journalism 2020, https://www. niemanlab.org/2019/01/in-europe-foundations-invest-in-news/ (2019), retrieved on 27 March 2020.

Marc Tracy, “After Long Wait, The Markup Is Ready to 'Show Our Work”, https://www.nytimes. com/2020/02/24/business/the-markup-tech-launch.html (24 February 2020), retrieved on 29 March 2020.

Jonas Trautner, “Die Berichterstattung über Google in den deutschen Medien im Zeitverlauf” (Master’s dissertation, University of Mainz, 2014).

Al Verney, “Let's work together to support quality journalism”, https://europe.googleblog.com/2015/04/ lets-work-together-to-support-quality.html (28 April 2015), retrieved on 27 March 2020. 
Daisuke Wakabayashi, Katie Benner, “How Google Protected Andy Rubin, the 'Father of Android”, https:// www.nytimes.com/2018/10/25/technology/google-sexual-harassment-andy-rubin.html (25 October 2018), retrieved on 24 May 2020.

Richard Waters, "Google turns on the charm in Europe", https://www.ft.com/content/o3d11b92-ecfo-11e4bebf-00144feab7de (27 April 2014), retrieved on 27 March 2020.

Jim Waterson, “Microsoft sacks journalists to replace them with robots”, https://www.theguardian.com/ technology/2020/may/30/microsoft-sacks-journalists-to-replace-them-with-robots (30 May 2020), retrieved on 1 June 2020 .

Stephan Weichert, Leif Kramp, Martin Welker, Die Zeitungsmacher: Aufbruch in die digitale Moderne (Wiesbaden: Springer VS, 2014).

Siegfried Weischenberg, Medienkrise und Medienkrieg (Wiesbaden: Springer, 2018).

Nicholas Whitaker, “Taking the initiative with data journalism”, https://www.blog.google/outreachinitiatives/google-news-initiative/taking-initiative-data-journalism/ (10 April 2019), retrieved on 27 March 2020.

Wikipedia, “Ökosystem”, https://de.wikipedia.org/wiki/\%C3\%96kosystem\#Verwendung_des_Begriffs_ au\%C3\%9Ferhalb_der_\%C3\%96kologie (2020), retrieved on 28 May 2020.

Chloé Woitier, “Les taxes YouTube et Netflix vont entrer en application”, https://www.lefigaro.fr/ medias/2017/09/15/20004-20170915ARTFIG00268-validees-les-taxes-youtube-et-netflix-devraient-aiderla-creation-en-france.php (15 September 2017), retrieved on 27 March 2020.

Armin Wolf, "Schlechte Nachrichten. Zur dreifachen Krise des Journalismus", https://www.arminwolf. at/2018/11/20/schlechte-nachrichten/ (20 November 2018), retrieved on 10 May 2020.

Julia Carrie Wong, “'I’ve paid a huge personal cost': Google walkout organizer resigns over alleged retaliation”, https://www.theguardian.com/technology/2019/jun/o7/google-walkout-organizer-claire-stapletonresigns (7 June 2019), retrieved on 26 May 2020.

YouTube Official Blog, "GNI YouTube innovation funding: supporting 87 news organizations in 23 countries to build video capabilities and innovate with new formats", https://youtube.googleblog.com/2018/12/ gni-youtube-innovation-funding.html (17 December 2018), retrieved on 27 March 2020.

Zeit Online, “Machen Sie mit bei 'Deutschland spricht'!”, https://www.zeit.de/gesellschaft/2018-07/ deutschland-spricht-2018-anmeldung (2018), retrieved on 31 March 2020.

Patrick Zelnik, Jacques Toubon, and Guillaume Cerutti, “Creation et Internet”, https://www.vie-publique.fr/ sites/default/files/rapport/pdf/104000006.pdf (2010), retrieved on 27 March 2020. 


\section{Appendix A: Written responses from Google}

Ralf Bremer, press spokesman for Google, responded to the questions via Email to the authors on March 25, 2020 and April 21, 2020.

The precursor to the DNI fund and the Google News Initiative was the Digital Publishing Innovation Fund in France, which pledged 60 million euros to publishers. Reports in the French media, by Frederic Filloux and others, put the fund in the context of the then-ongoing French debate about ancillary copyright. Is that correct?

This was a commitment that built on the commitments we made back in 2011 to increase our investment in France - including our Google Arts \& Culture Lab in Paris. As we have long said, we recognise the internet has changed the way we find and access information, and that publishers are facing challenging business environments as a result. News is important to Google, and as such we have worked with the industry for more than 20 years to help provide value to them.

Following the French debate about ancillary copyright, the French government suggested a round of negotiations between Google and the French publishers which led to the creation of Fonds pour l'Innovation Numérique de la Presse (FINP), a 60 million Euro fund over three years to support long term innovation for the French publishers. This agreement was signed by Google's CEO at the time, Eric Schmidt, and the General and Politic Press Association under the umbrella of the French government.

How it worked:

- About 180 news websites - both established legacy publishers and online only play- ers - were eligible to apply for projects that demonstrate innovation and new thinking in the practice of digital journalism.

- In terms of governance, the French fund was all about collaboration between Google and the French press through a specially-founded body (registered as an association) - The FINP or Digital Publishing Innovation Fund.

- The FINP was independent from both Google and the press regarding its daily operations and was overseen by a board composed by 7 members -3 press representatives, 1 Google's representative and 3 independent experts from the digital industry. The board was in charge of deciding which projects to be funded based on the FINP's Director recommendation. Projects were co-funded to up to $60 \%$ from the FINP with the remainder allocated in resources by the recipients. The cap for projects was $\mathrm{M} 2 €$ per year and per publisher.

- The list of selected projects was public and broadly shared (see example of article here reporting on the 2 first years of operation for $M_{31.8} €$ ).

Did the French fund pay out the full 60 million euro?

The French Fund allocated $55,985,112 €$ to projects. All projects were closely followed from both an execution and an accounting standpoint. Most of the projects are now finished and so the money is released. But a few are still being developed as the projects could last for up to 3 years. An independent accounting firm is in charge of the follow up. A very small proportion of the fund was allocated to operating 
and administration costs such as third party auditing and knowledge sharing (e.g. an event with Wan IFRA).

Was there ever a full list of projects for the French fund published?

The list was published on the FINP.FR website and details shared with publishers at a full day event. The website is now closed as the Fund came to an end (you can see the archive records here though the videos no longer play).

Tallying the French fund and the DNI fund, that would make a total of 200 million euro paid out to European media from 2013 to 2019, is that correct? Can you give an exact figure?

M210€ has been allocated in total for both separated initiatives Digital Publishing Innovation Fund in France (FNIP) and DNI fund. The vast majority went to publishers. As is normal for funds, a very small proportion was used for operating costs including third party auditing and knowledge sharing (e.g. ensuring insights gained from the programme were made accessible to all publishers). This was less than $5 \%$ for the DNI.

The DNI fund published an annual report for 2018, but not for 2019. Why?

The DNI Fund published a 2016 - 2017 report as well as a 2018 report.

The DNI Fund also:

- made all projects public once selected,

- produced some innovation stories in the spirit of sharing the knowledge,
- organised 2 DNI Fund EMEA events in Amsterdam and in Paris with +250 attendees from the entire news ecosystem to share the learnings or the projects and many local/regional events.

- When the DNI Fund came into an end we shared some of the learnings and reported on the last round here.

- As most of the projects take multi years to be developed we decided to wait until 2020 and to monitor the progress to publish a 2019-2020 when it will be the more relevant for the industry in terms of knowledge sharing.

- We are currently working on a 2019-2020 DNI Fund "final" report and we aim to publish it in the coming months. This report will actually cover all the duration of the DNI Fund and aim to share relevant learnings and resources for the entire news-ecosystem.

Does any of the 140 million euro paid out by the DNI fund contribute to the 300 mio. dollar pledged for GNI?

No. Those are two different initiatives with two different and specific budgets.

Is there a systematic overview over all GNI projects and recipients to be found somewhere?

- All GNI Programs and Initiatives are listed here: https://newsinitiative.withgoogle. com/programs/

- All GNI Challenges recipients are listed here: https://newsinitiative.withgoogle. com/innovation-challenges/funding/ 
- All DNI Fund recipients are listed here: https://newsinitiative.withgoogle.com/ dnifund/dni-projects/

- We will continue providing transparency and knowledge sharing reports regularly about both initiatives and we are currently working on a DNI Fund wrap up report. Most of GNI Challenges projects are still early stage as the initiative was launched about one year ago and we will share knowledge as soon as the recipients who own the projects, as well as the Intellectual property of the projects, will consider there is enough to be shared to make it relevant for the entire industry.

\section{How many funding applications were rejected} by the DNI council and for what reason?

- Over 6 rounds of application the DNI Fund:

> received 5,154 applications,

> shortlisted 1,315 for interview with applicants,

> selected 662 projects worth $€ 140,689,269$ in 30 european countries.

- All projects were reviewed by a project team made of Google employees and external assessors (For example, round 6 project team members listed here at the bottom including three external industry experts).

- All projects have been reviewed by at least three people, including one external industry expert.

- All projects were assessed against specific and public criteria:

$>$ Impact on news ecosystem

> Innovation \& use of technology
Feasibility

> For Round 4, 5 and 6, a monetisation opportunities component has been added and publicised for projects $=\mathrm{ts}>50 \mathrm{k}$.

> For each round of funding, specific T\&Cs were communicated broadly and published on our website (see example here).

- A Council made up of Googlers and external experts from the European news industry and beyond, intended to reflect diverse points of view, was in charge of making the final selection based on project team recommendations and to oversee the DNI fund operations (see rules of governance here and the list of DNI Fund's Council members here).

- In order to respect the integrity of the applicants, we didn't share the names of the applicants but only of the recipients.

- Also, to reiterate: the Funding was not about Google products and the recipients own the IP. The only purpose of both the French Fund and the DNI Fund was to stimulate innovation for the benefit of the entire news-ecosystem which was reflected in the diversity of recipients and the diversity of topics.

According to media scholar Emily Bell DNI funding was taken from Google's marketing budget. Is that correct and does it apply to the French fund and the global GNI as well?

We don't break out internal funding. However, I can confirm this did not come from a marketing budget. 
Google labels publishers as "Partners". Some of the people in the industry we talked to feel that is not a fitting term since they are your customers and you are subject to their coverage. What would you say to this perception? "Partner" is a term we use to refer to companies with which we have a business relationship or as it is the case in DNI and GNI with whom we develop innovative technologies like AMP or Subscribe with Google. That does not exclude that publishers are also our customers as we are their customers as well, e.g. when it comes to ads in their newspapers or on their websites.

Back in 2018, there was a story in the Financial Times about an e-mail by Madhav Chinnappa to a group of publishers on the DNI working group giving Google's position on the Copyright Directive, arguing why it was "bad for the internet". For our current study, we heard from German publishers that a similar e-mail was sent to publishers about the EU's upcoming ePrivacy Regulation, claiming it would affect both Google and the publishing industry negatively. Do you feel that e-mail constitutes a lobbying effort visavis the publishers?

The quote from Madhav's leaked email was about the Open Letter about Article 13 from many internet luminaries including Tim Berners Lee. It was a response to the DNI Working Group who asked for more information about the Copyright Directive and Google's position on it. If you read the email, it links to independent research and information as the group wanted to educate themselves more.

More generally, it is standard practice for governments and other relevant parties to ask companies for comments on proposed laws. We support updating copyright rules for the digital age and, along with many others, have provided, and continue to provide, feedback on how the law may impact the way people access news content online.

We build technology that helps people and creates economic opportunity. Our success in doing that means we have a responsibility to be an engaged and helpful partner to policymakers as they debate topics related to our products and partners. That also applies in regulatory enforcement cases - we have made our case to regulators and others involved in the process - and we'll continue to do so.

There is the European Innovative Publishers Council that opposes ancillary copyright. Many of the members in the Council are DNI recipients. Was Google somehow involved in creating this group or does it coordinate with it?

We support a number of interest groups and research programs around the world to help public and private institutions pursue research on important topics in computer science, technology, and a wide range of public policy and legal issues. That includes EIMP that helps give smaller publishers a voice.

Following Google's example, Facebook also announced a 300 million dollar fund for news. How do you feel about Google as a model for other companies? Do they live up to the model? We try to focus on what we can do given our role in the ecosystem and it's not our place to comment on how others operate. 


\section{Appendix B: Interview with Madhav Chinnappa, Ludovic Blecher and Ralf Bremer}

The interview took place on March 26, 2020 via Google Hangouts between the authors, Ingo Dachwitz and Alexander Fanta, as well as the Google Managers Madhav Chinnappa, Ludovic Blecher and press spokesman Ralf Bremer. The transcript was authorised by Google before publication.

n Let us start with a quick introduction, then move on to questions.

Madhav Chinnappa: I've actually worked in the news industry my whole career. I started at Associated Press television. That was a startup that was created out of AP on the television side. I worked on all parts of the business there. I was acting Asian editor during things like the Hong Kong handover, the Afghan civil war. I ended up moving to the more business side of it. I moved for a year to M\&A-role in a UK media company which I didn't really enjoy. Then I moved to $B B C$ and ended up being head of development and rights. So I actually come from a television background. At the $B B C$, I was working on the relationship that the $B B C$ had with news agencies and their partners like the EBU and Al Jazeera. I established a working relationship with $A$ l Jazeera after 9/11 and things like that. My job was working with all the people that provided news to the $B B C$ and also the people that the $B B C$ provided news to. Increasingly, what was happening was that the digital teams were coming to me and asking me questions like "Can we do this?". So I got involved more on the digital side. What I was realizing then, is that the job was changing so much and that technology and digital are really important. And I didn't know anything about technology. I often joke that I'm the technically dumbest person at Google. But I wanted to learn. Because the changes that were happening, I thought, were so profound. The story that I used to say at the $B B C$ was, if you're the editor of the 10 o'clock news, you never had to think about whether someone was watching it on a Sony television or a Panasonic. Whereas now you have to think about how this is going to look on Android or iOS, how is it going to look on this phone, how is it going to look on a tablet? It is just a much more complicated world that I wanted to go and learn about. Also, I used to deal a little bit with Google and Google was not the easiest company to deal with. I used to say two things to them. One is: “I don't think you quite get news," and two, "whenever you do something you're always doing it with the New York Times or the Washington Post". And I got called up nine years ago and somebody said: "Hey, you know these problems that you're talking about - we're trying to work on them. Would you like to come and work here?" Which I thought was offering me a job . I was so wrong. I had to go through all the Google interviews. It was crazy. But the career I've had at Google has been, I was the first person outside the US to work on what was called news product partnership and that was, at the time, just about Google News. We didn't have a lot of news products at the time. Then I worked on DNI and GNI. So everything that I have been doing has been on that cross between the technology and news. But very much from a news perspective because l'm a news person. 
I actually think that a lot of the friction that happened between Google and the news industry is cultural. They're two different cultures. But that's a little bit about me. I'll shut up and let Ludo talk. He's got a much more interesting background than me.

Ludovic Blecher: First, I would just say everything I do is with this journalist mindset. I'm a journalist who was always involved in digital transformation. Back in 1998, I was finishing journalism school. My dream was to be a reporter at Libération, which is a French daily paper, and be in charge of digital transformation. [That was] for one reason. Everyone was looking at digital as a way to display more of what you were doing in print and I was looking at it as a new medium. In 1998, I wrote some research called "Liberation, which strategy for new media". Three years after, I was hired by Libération. First as a reporter, then I joined the website of Libération, always wearing two hats. One was doing the classical reporting, politics, I covered terrorism, Corsica. Also, any kind of stuff including technology and political and social affairs. But I was always coming with new ideas to create new narratives using online. And at the age of 29, I became the youngest editor in chief of Libération, for one reason. I had wanted to leave the paper because I saw they were too low in achieving digital transformation. But then a new executive director of the paper was appointed. At the time the news room was voting for the guy, I voted against him. I had never met him before. He asked me to come to his place. I was with him the day after and he said: "Everyone says you have ideas for digital. You are going to be editor in chief and also in charge of digital." I became both editor in chief and CDO. To make the long story short, we went through this transformation. I set up the first subscription model by 2010 for Libération, together with someone coming from the music industry. So trust me, I know a lot about the decisions here, how to change the business and how to go through the massive complexity of dealing with change. And dealing with journalists, which is not easy even when you are a journalist. Dealing with business folks, you use words such as product. Because at the end of the day you have readers which are using the product. So I went through all that. I left Libération because I was kind of,- I felt to be in silos. Between the newsroom on one side and the product folks on the other side. I had the opportunity to become a Nieman fellow, at the Nieman Foundation for journalism at Harvard. I spent one year at the MIT working at the Media Lab on new narratives and new formats for journalism. And at the business school [working] on monetization of news, focusing on subscription. It was 2012, we were not that many to work on subscription. My field was to create a toolkit for small and medium newspapers that wanted to set up a subscription model. Then back to France, Google and the French publishers reached an agreement. I was not part of the negotiation but they decided to setup a fund for innovation in France. Both the publishers and Google reached out to me and said: "You are a journalist, you know a lot about innovation, you know the publishers; can you think about a meaningful 
way to operate and push the transformation?" I set up the French fund, I was the director of it. Then I joined DNI to work with Madhav on a very big, and maybe the biggest effort ever done to stimulate journalism and new thinking in the practice of digital journalism in Europe. I am someone who doesn't really care about the medium or device, but about journalism. I think there are no good or bad forms of media [meaning: paper, mobile, TV, assistant]. I'm not the one that is saying that paper will disappear or mobile will take over everything. I'm a more of an and-person than an or-person, I see there are different ways to write a story and to earn the relationship with the audience. Everything I have done was with this idea of what it is to be in the publisher's shoes, when you have to deal with complexity, in a very, very complicated time in terms of economy that doesn't give you that much room to do something that is massively important, which is trying new things. So I've done that with this spirit. I'm still a board member of a newspaper in Lebanon, where I try to keep an eye on what is the complexity on a day to day to deal with economics and stuff. Now I'm in charge of a new program called GNI Innovation Challenges, which has the same spirit to stimulate innovation, but at a more global level. We implement code for projects in every region of the world.

- How would you describe Google's European digital news initiative to a person that is not familiar with the matter.

Madhav Chinnappa: I'll take that [question] because I had to explain it to my family. The way that we used to explain DNI was that it was our initiative in Europe to try to help the overall news ecosystem across three pillars. We had product, training and research and innovation. And the DNI fund was the innovation piece of it. But the two other pillars are as important in my view. Indulge me for a moment on the origin of DNI. I'm a comic book fan, so I like a good origin story. About five years ago, we had a number of publishing partners we've worked with come to us and say: "Look, these are very, very difficult times. The Internet has fundamentally changed the business models. Everybody has access to information, everyone is getting access to the advertisers and access to audiences. That has been very, very difficult. And we think you should do more. We don't really understand what you're doing." Google at the time responded, they were saying: "Well, we do lots of things, we do care about the ecosystem. Look, we've got search that gives you all this traffic. We've got ad tech that gets you all the help for revenue. You've got Trends and stuff that give data and everything." It was very much a product-oriented view of it. And there were lots and lots of products. But if you were a news publisher, you would look at all these things like: “Where's the story? It doesn't really make sense to me." So what we tried to do is create DNI to be a bit more coherent both internally and externally. And don't underestimate how important being coherent internally is as well. With a small group of publishers, we said: "Look, we really do care and I can go into why we care. Tell us what we should be working on." That's where the three pillars came from, 
because they said: "We really need help on certain product things. We really need help on the kind of tools and training that will help the journalists be the journalist for the 21st century." A very different world from when I was in the newsroom. I'm that old, you can tell from my gray hair." Also we need help in innovation. Everybody talks about it, but it's very difficult to do." So on the product side, we create a product Working Group. One of the challenges they were facing was mobile, video, monetization. So we ended up developing AMP around mobile. What they were saying was: "There are all these problems, everyone's moving to mobile, and all these platforms are coming to us asking you for different things." We looked at that, the smart techies looked at that, and said: "Well, that's because the mobile web is too slow. And that is not a problem Google can solve." That is why they came up with an open source initiative for the ecosystem to work together on. With video, people said "everyone's moving to video, but it's so complicated." So we worked on the YouTube Player for Publishers program, which allows news publishers to basically use the YouTube back-end at no serving cost and all the YouTube infrastructure. On monetization, there were two things. One was getting more serious around ad blocking. And the most recent stuff has been around Subscribe with Google. So again, there's a big product piece that was under DNI, that's also going forward with GNI. The tools and training, quite similar. And the Innovation Fund, the discussions about why we should do an Innovation Fund were really interesting. Actually, in some of the beginning conversations, there were editors and CEOs who said, "look, we really know we need to innovate. But it's very hard to innovate, when you have to do your day job all the time." That really resonated with me because often when I was working for a news company I felt like I was trying today to do the job that I did yesterday better, rather than think about what I needed for tomorrow/the future. A publisher said to us, "honestly, we need funding, to be able to have that bandwidth in that space to try innovation. Some may succeed and some will fail because that's the part of innovation." That's actually where the DNI fund came from. Ludovic Blecher: If I may, I would summarize with three key words. I would say collaboration, solutions, stimulation. I would say it's first of all about collaboration, training to understand each other better. When you start, you take people, publishers and Google, tech and product person, at the same table. They speak about their issue, you try having this conversation, it leads to collaboration, and then you see what can be the solutions. When we are the product solution, we try to come up with it. And it should be in the most open approach possible, like AMP, open source. They had an issue with how you can speed things up, how things are displayed on mobile. When we can have a solution, we try to have it. Collaboration can lead to solution. But beyond collaboration and discussion, as Madhav explained, the day-today operations are killing all your bandwidth. So it goes to stimulation. We came up with this idea of saying, "we will try to give you time and come up with a kind of initiative that would be a 
forcing function for you to just to step back from the daily operation and think about something. For trying new things you would not have the bandwidth or the funding, sometime, to do." In some ways, the application process to the DNI fund became more important than the funding itself, because this was the stimulation, anyone to have the opportunity to come with idea and move forward with it, whether it was selected or not.

As you say, the DNI fund was funding innovation - what was your working definition of what media innovation actually means? And can you say a bit about in terms of the projects you saw, what worked and what didn't?

Ludovic Blecher: I will tell you about definition first and then I give you the rest. We had a lot of conversation with Madhav and there are two things we decided not to define. The first one was innovation. And the second one was quality. Who are we to define that? So we were thinking about original journalism. Of course, the aim at the end of the day is to produce quality and to defend journalism. And we have the patience, the soul and everything for that. And innovation. How would you define innovation? It depends on your starting point. It depends on your own starting point. In the media landscape, innovation is not the same for a small player as it is for a legacy player with hundreds of years of history and it is different depending on the country. So we asked people to explain to us why their project is innovative and to give us indicators to help us assess the level of innovation depending on their starting point.
Madhav Chinnappa: We did this in the craziest way possible. Because we didn't define innovation and we didn't even define what news was. We wanted people to do that. That was intentional, because we didn't want to be restrictive. We wanted to be as open as possible, and let people come to us. I think that's important, at least from my perspective, and I need to give huge kudos to Ludo who set up the process with the project team and the jury, letting all the people and experts actually look at this through the whole way. A process was designed without having an outcome in mind. What we're trying to do is stimulate but we didn't know what that would look like. The process was designed to try to do that intentionally.

\section{And how did that work out? What would you say after three years of funding?}

Madhav Chinnappa: Go for it Ludo. I'll let you speak for once.

Ludovic Blecher: It would be kind of odd to have just one outcome and one analysis. Because we saw many things, and many trends. So first, some surprises. So what surprised me first is [that] the best idea, the most disruptive is not necessarily the best outcome. Real innovation lies with execution and implementation and iteration. You can have an idea that is excellent, [but] if you don't implement it the right way, if you don't listen to the way people are using it, if you're not shifting, iterating, it can end up not being the right path. In the way we designed the process, we gave the flexibility to people to kind of shift and pivot. The second 
thing that really surprised me was - at the beginning, we were a bit shy because we wanted to make very clear that it was not about Google products, and it was not about us, that we are giving room to innovators. We said: "Of course you own the IP. You don't have to apply with Google products. And guess what, we're not going to speak about your project at all." And actually, the innovators came to us and said: "But we want to share, we want to learn from users - can you help us with that?" So this idea came from the ecosystem, to go into more collaboration. We saw after round two and three that the number of collaborative approaches in some way became the new disruption. It was fantastic to see this news ecosystem coming together with different publishers, that were sometimes competitors, with academics and publishers. There are many examples I can mention with startups and publishers, and so forth and so on, that came together to try to solve big things. And that also wanted to share the learning within the industry, so everyone can grow together. To me, that was the most important learning of this initiative.

Madhav Chinnappa: The learning I have from the beginning stage, we were - and this was my fault - we were very conscious that at that point, people would be very sceptical about why we were doing this. So we said, look, this is not a PR exercise. Of course you own the IP. The worry [among publishers] was, this was either a PR exercise or some kind of fishing exercise for IP. So we said: No, no, it is absolutely crystal clear, it is all your IP, it has got nothing to do with Google. You don't have to do anything with Google. And it's not a PR exercise. You don't need to talk about it, we're going to default to projects [being] confidential. As soon I said that, the feedback was people wanted to talk about it. We did it for those reasons. And we iterated through the rounds. We changed that as people did that. Also, we became more focussed via themes. I think the thing that has been really interesting to me has been a cultural change. This is the learning for me - it is that, yes, they were working on technological product innovation projects. Brilliant. But the really interesting learning for me is how that process created a cultural change within some of these organizations. And I'll give you one of my favourite examples. And it's with a local publisher in the UK, called Archant. They had a really good CTO, and she came with a project around voice and using their archive and some really clever things about monetization. She told me the story afterwards, it turns out she had taken this project to her board. And they had said no. Then she went to the DNI fund. We said yes. She went back to her board and said: Look, Google and the jury, and all the people in the jury think this is a good idea. They went and did it. She said it actually helped change the culture within the company. All of a sudden there was this light bulb that went off. They ended up restructuring some of the way in which they work in the company. One good thing is that she got more power, she's able to do more stuff. For me, those are the stories that are brilliant. Because projects are fantastic, not to do them down. But it is when that innovation project is bringing lasting change 
that it does what we've tried to do through DNI, GNI, which is help move the industry on.

I have another kind of definition question for you. Would you say that the DNI fund was or the GNI generally is philanthropy? How would you position it on the axis between a commercial activity and a philanthropic altruistic activity?

Madhav Chinnappa: I guess I put it somewhere in the middle. Because it's a bunch of different things, but I think we should understand the reason. It goes back to [the question]: “Why does Google do this stuff?" Why does Google cares about journalism? In my view there are two reasons for this. One, there is a values-based reason. Google is a company that is about trying to give access to information, to make information universally accessible. A huge part, and it's hugely important to that mission, is - if there is a degradation of the quality of information that is out there, what we do - trying to connect users with quality information - will become more difficult. So there's a values perspective on that. Including, that we think that - and we've been clear about this, Sundar [Pichai] has been clear about this from a values perspective, we share a lot of the same values as the news industry about how an informed citizen makes for a better society. But there also are business reasons behind this. Google is an ecosystem company. The way that it makes money is through the ecosystems it operates in. So it thrives when the ecosystems thrives. That's why, when you look at our businesses, especially the ones that relate to news, they're all revenue share-based. Our ad tech: revenue share-based. YouTube: revenue share-based. Play: revenue share-based. With the vast majority going to the publisher, the creator, the YouTuber. Therefore we're incentivized to help the ecosystem, and in this case, the news ecosystem, to thrive. That's why it's a bit of both. But also, I would say, going to the point that Ludo made earlier, which is about collaboration and dialogue. Publishers were asking us for that. And we have always tried to design things based on feedback. One of the things that l've seen culturally change is the company, in the time that l've been here. When I was at the $B B C$ complaining about Google, to Google people, it felt very much like a blackbox. I think we've spent a lot of effort and time trying to not be a black box, to listen to people, to understand things to communicate more, to communicate the way that we operate more. Look at the website "How News Works" and things like that. They are based on feedback from publishers. Publishers that say: "You need to be better at this, you need to be better at this." Also, going back to the point I made about culture: Google is a tech company. Technology has a culture, news people have a culture, and they are quite different. But news people like to talk to humans. So this is kind of a cultural thing, which is: Here, make the product. Let's see how it goes. Whereas news people want to go: Where does the product come from, what were you thinking, tell me more about that. I think that we have come a long way, including getting people like Ludo, like myself, like my boss Richard Gingras, who come from the news industry, to bring that kind 
of sense and balance to that discussion. So it's not just a purely technological discussion, we are thinking more broadly on that. But it's also about the opportunity and the ecosystems that we are involved in. And it's about the people that you work with as well.

Ralf Bremer: Let me just add one point. I think there's a third dimension. It's not just philanthropy or business. The third dimension is the social responsibility, doing the right thing, and not being ignorant to the things that are happening outside Google. We are seeing that movement outside our company, and we act in a way where we think it's the right thing to do. You can see it in the current crisis. But you can also see it when you look at our activities regarding environmental sustainability and climate change. And you can see it in the cultural space, you can see it on many social occasions and in our work with social organizations. I think that's part of Google's culture. So it is not either philanthropy or business. It's also about responsibility.

Madhav Chinnappa: People always ask me how it was to come from the $B B C$ to Google, they're like, wow, that must be so different. And yeah, there is a lot of differences. But one of the things that I find amusing is the similarities. One of the similarities is, in the $B B C$ speak, with the public service ethos. There is a public service ethos within Google. There's a third dimension beyond those two.

- Let me ask about another dimension. In 2015 , when the Digital News Initiative was first announced, Google was under a lot of pressure in Europe. Germany and Spain just introduced their forms of ancillary copyright. Italy had debated a web tax. Was it a coincidence or did the News Initiative correlate with this political situation that was tough for Google? It seems DNI was born under the wish to avoid tougher regulation.

Madhav Chinnappa: I would characterize it slightly differently. It's very easy sometimes to think there's a direct causal link. I think that the pressure and the things that were happening were a bit of a wake-up call to Google to go: "Wait a second, we seem to be very misunderstood here. Because we think we're doing all kinds of good stuff and then there's people saying these things. What's happening here?" And that's when we used this kind of trusted group, focus group with the founders of DNI to say: "Hold on a second, we feel that we're doing quite a lot, but we seem to be misunderstood. Can you help us do the things that you think we should be doing? Help us shape this in a better way." That is where DNI came from, it was talking to the publishers about: what are the right things and the ways that we should work within the ecosystem? What's good for the ecosystem? That is how I experienced it.

Before, you described the three pillars of DNI and how GNI is a larger thing now, how it has different pillars with a different emphasis. What would you say is the difference between DNI with the fund and the larger GNI initiative?

Madhav Chinnappa: That is one of the cultural things about technology companies, they like to experiment and iterate. So you always 
have to do something slightly different as you're moving forward. Whether it was product training or research and innovation. When you do something new, you don't stick with those, you make it something different. In terms of the differences, there's one other difference: GNI is global. DNI was European. But the reality of what we understood is that if you look at two of the three pillars of DNI, they were actually global without it being explicit. The product stuff was global, because we do global products. The tools and training was global. Our News Lab team, they operate globally. The training stuff, the Reuters report that we are one of the funders of, that was global. So there was a natural evolution that way. The other thing that is different is a deep focus on the business sustainability elements of it. This means we've gone deeper in certain ways on the GNI. We have things like these labs program, whether that is a subscriptions lab, or ads, where we are taking a small group of people in different regions, going deep with them on a lab. And I think that is much more focused around business sustainability. That's a different approach that we just definitely didn't have under DNI.

Ludovic Blecher: And we are learning. At some point, regarding funding for new projects, we say, should we just fund innovation for the sake of funding innovation? Or should we hear what the publishers have to say, what the ecosystem has to say, and then help them in the direction they're asking us to provide a support. The first Innovation Challenge we've done in Asia Pacific, we decided to have a spe- cific theme with a specific focus. It was not just about innovation, but about how can you innovate through revenue coming from readers, donations, subscriptions, membership, churn reduction, and so forth and so on. That goes to what Madhav was saying: this is really about sustainability. In another market, in Latin America we wrote [in the call for project] about what the market wanted from us, and we went for a new news product. In America, the big thing was about local, so we made a call for local projects only. The current call in North America is focused on business sustainability, which is a permanent concern, and diversity, equity and inclusion. So we are listening.

Madhav Chinnappa: Under the fund, we actually iterated as we went along. We started very open, then we heard the feedback that actually monetization is the big challenge. And through DNI funds, through previous rounds, we focussed around that. With GNI, we very much did a similar version of that, which is listen to the industry about what's right for their region. And, you know, the APAC one is a really good example of that. Because when we went out to Asia, we were talking to publishers about the challenges that they are facing and how we could help on the innovation side. They were saying, look, we are not anywhere near around reader revenue. We see what's happening in the US and in Europe. But we really need some help in that way. And I was like, okay, that'll be the theme for APAC round one. I think that the dialogue to understand the challenges has gone into a much deeper level with GNI than we had with DNI. 
Ludovic Blecher: We saw some similarities in terms of outcome. We started one year ago on a call for projects about reader revenue. Innovation takes time - that's one of the learnings as well - it takes time to implement. When I was still able to travel, about a month to go, I went back to Asia. I looked at the progress and I met with publishers. I was in Japan and I met with the person managing the project for Asahi Shimbun. Very legacy company, very powerful, with a very Japanese culture. What was interesting was to have him saying publicly the following, I'm going to read it to you: "We've learned, sharing ideas is better than hiding; once we share with others, including players in different industries, we became better and we came up with new interesting perspectives." While going through the process, we were suggesting they come up with this new mindset, the structural change - "maybe when we grow if we share more on that."

Madhav Chinnappa: For me, this is one of the really, really important learnings: The process can be almost as important [as the outcome]. And this process can lead to change that you wouldn't have expected. In the beginning days of the DNI fund, one of the things that I was absolutely petrified was that, frankly, we would disappoint more people than we would make happy just by the fact that we're not going to be able to say yes to everybody. But you know, thanks to Ludo and the project team, the process that people went through -, actually even people who didn't get money have gone out of their way to thank me and Ludo because it helped them thinking. That was just beautiful to see, because there are a lot of difficulties in the overall news ecosystem. At the end of the day, I think we will get to a healthy sustainable news ecosystem if we're able to tap into a lot of people that are working on stuff. Let them have the space to innovate to build what they want the news ecosystem for the 21st century to be.

Could you reflect a bit on the role that you and Google are playing for the news industry in the crucial phase that it is in now. You just described the fund, the fellowships and the conferences Google hosts and sponsors and so forth. How does it feel playing such an important role for such an important industry in this crucial time?

Madhav Chinnappa: It is something that we take very seriously. I always use the word ecosystem. In the old days, when I started, it was a news industry, it was very verticalized. It is now an ecosystem with lots of different parts and lots of different players in that. And I think we try to take our role in that very seriously. We understand that we are quite a significant player. You know, you look at on the digital side, if you look at the traffic sources, and the 20 billion clicks a month that we send to publishers and all that stuff, 14 billion in revenue that our ad tech does. We understand that we are a significant player. Well, you know, with great power comes great responsibility. We take these responsibilities very seriously. But we also try to do it in a way that is based around dialogue and collaboration. So it's not like there are six people who sit in a darkened room at Google and say we need to do XYZ. We spend a lot of effort 
trying to talk to people directly, trying to go out there. This is why we have these conferences, to hear from people. This is why we try to do them in both structured ways and unstructured ways, right. We do this in an open, transparent, collaborative way. Ideally, you know, based on dialogue.

Some media scholars, such as Emily Bell, argue that it could be an issue for journalistic independence when a company that is subject to coverage is also a major provider of product infrastructure and at the same time funds media products, trains journalists. Another scholar, Efrat Nechushtai, conceptualized “infrastructural capture," where a company becomes dominant for the distribution, for the monetization of news. Do you think that there is a threat, maybe even inadvertently, that Google could kind of capture media, arrest their autonomy?

Madhav Chinnappa: No. I believe in the power of journalism and the importance of independent journalism. Good journalists know what good journalism is. They're not going to be affected whether Google is their ad tech provider or whether someone else is. Journalists have had to deal with this from the beginning days. And it's evolved over time, if you look at the history of journalism. Modern journalism has always been about independence. I don't see that as a factor, because I believe in journalism.

Ludovic Blecher: Journalism is all about Chinese walls and church and state [separation], as they say in the US. This is something we have replicated in the way we were handling the DNI fund. We had Chinese walls. Everything that was discussed within the project team stayed within the project team, and couldn't be shared with anyone in product, in business, in marketing. I strongly believe, as a journalist, that the essence of journalism is the slogan of independence. You cannot kill that.

Madhav Chinnappa: Just to build on that, you know, just to be clear: On DNI, we made sure that our product people are away from the innovation stuff. Because we never want anybody to think we were using it to steal IP. We did a lot of Chinese walls. My team has signed actual contracts that said, you will not be talking with your other colleagues about this. This was over and above their regular employment contract.

- But wouldn't you agree that Google's brand among journalists profited from the News Initiative?

Madhav Chinnappa: I don’t know. You tell me.

- The Reuters Institute figures indicate that Google is the most popular of the tech companies among media organizations. But I guess the larger question is the infrastructural dimension. The Chinese wall is a concept from the era of classical advertising. But now Google not only is the intermediate for the advertiser, but it also drives traffic, it does monetization via subscriptions. And it helps to sustain journalism in other ways. Don't you think that there is an issue with having such a dominant effect on industry, even if that is not purposefully misused? 
Madhav Chinnappa: Going back to the Reuters stuff, when you dig into the data around things like traffic, you realize when you look at the search traffic, in almost fifty percent of that traffic where Google is the source, it is what they call direct. It is people searching " $B B C$ " because they're too lazy to put it " $B B C$. com". On the search dominance thing, from a news perspective, you always have to look one step below that. The other point about whether we're the most liked one - I think we are there not based on, "hey, everyone's nice there". We're based on our actions and the positive impact that those actions have. It's not just because we have a nice conference, and everyone's like, "hey, isn't this fun?”. Journalists and publishers are way too sceptical to do that. It's actually, publishers value the things that we have been doing. And they value it, not just because "hey, it's great". It's because they've helped build that. This is the collaborative dialogue about everything that we're doing. That is useful for the overall piece. In terms of the influence bit, I will come back to that the journalists are always going to be sceptical.

Madhav, you mentioned the internal separation of units. Like product people, they don't interfere with the DNI fund, for example. Are there other steps, other measures that that you've taken to prevent any forms of unwanted influence?

Madhav Chinnappa: From the DNI fund perspective, probably the most obvious one was the Council. It was a Council of twelve people. Three of them were from Google and nine of them weren't from Google. And it was a simple majority to take decisions. Even if there was a deadlock, the person who broke the deadlock was the chair who was a non-Google person. So we definitely tried to make sure. We were very, very conscious that people would perceive this in a certain way. So we tried to build it in a way that demonstrated the way that we wanted it to be done. The innovation fund was completely independent from the product working group. We said very specifically, if you are on our product working group, you cannot be on the innovation fund. Because we want to keep those two things completely separate. They have a very different purpose behind it. On the middle pillar of tools and training -, please feel free to talk to Reuters about whether we put any conditions upon them, which we didn't. Because that was about research which had to be independent. This goes slightly circular, back to the first round when we said we're going to default to not talking about your projects. That was done because we knew that people would think oh, they're just doing this for PR.

\section{- GNI was scheduled to run for three years until} the end of 2021. So what will happen after the three years, what will happen after 2021?

Ludovic Blecher: Innovation takes time. We still have a lot to do. Let's discuss that in six months or one year because I don't have the answer yet. We need to do the right thing. 


\section{Tables}

Table 1:

Table 2:

Table 3:

Table 4:

Table 5:

Table 6:

Table 7:

Table 8:

Table 9:
Overview of 25 respondents .24

Summary of Google funding programmes for news media.....................................27

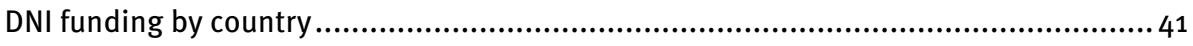

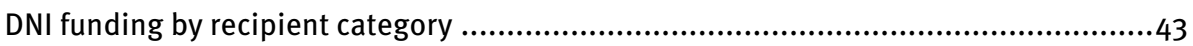

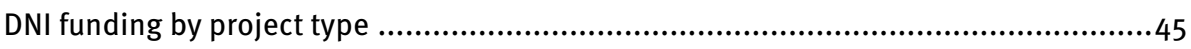

DNI projects in Germany by recipient category ..................................................... 46

All DNI grants over 300,000 euros in Germany ................................................. 48

The 10 biggest German recipients of grants from Google's DNI Fund ...........................50

Use of Google products in German newsrooms ...............................................76

\section{Notes on the authors}

Alexander Fanta is a Brussels-based journalist for German digital rights news website netzpolitik.org. He writes about tech policy in the European Union. In the past, he was a Google Digital News Fellow at at the Reuters Institute for the Study of Journalism at the University of Oxford. From 2011 to 2017, Alexander was a staff writer at the Austrian Press Agency (APA), where his beat included the OSCE and UN organizations in Vienna.

Ingo Dachwitz is a communications scholar and political journalist based in Berlin. He works for the award-winning investigative platform netzpolitik.org and as a guest lecturer on the political economy of digital media at German universities. Ingo writes and speaks about data policy, surveillance capitalism and the digital public sphere. 
OBS-Arbeitspapiere Infos und Download: www.otto-brenner-stiftung.de

Nr. 43 Streitfall Vermögenssteuer - Defizite in der Medienberichterstattung (Hendrik Theine, Andrea Grisold)

Nr. 42 Mauer in den Köpfen? - Einstellungen zur deutschen Einheit im Wandel (Ayline Heller, Ana Nanette Tibubos, Manfred Beutel, Elmar Brähler)

Nr. 41 Wählen mit 16? Ein empirischer Beitrag zur Debatte um die Absenkung des Wahlalters (Thorsten Faas, Arndt Leininger)

Nr. 40 Armutszeugnis. Wie das Fernsehen die Unterschichten vorführt (Bernd Gäbler)

Nr. 39 Stumme Migranten, laute Politik, gespaltene Medien - Die Berichterstattung über Flucht und Migration in 17 Ländern (Susanne Fengler, Marcus Kreutler)

Nr. 38 Rechte Allianzen in Europa - Wie sich NationalistInnen gegen die EU verbünden (Malene Gürgen, Patricia Hecht, Christian Jakob, Sabine am Orde [Redaktion])

Nr. 37 Zwischen „Flüchtlingskrise“ und „Migrationspakt“ - Mediale Lernprozesse auf dem Prüfstand (Michael Haller)

Nr. 36 Krimis, Kontroversen, Kochrezepte - Das Regionale in den Dritten der ARD - mit aktuellen Programmanalysen von rbb und SWR (Joachim Trebbe, Eva Spittka)

Nr. 35 Agenda-Setting bei ARD und ZDF? - Analyse politischer Sendungen vor der Bundestagswahl 2017 (Marc Liesching, Gabriele Hooffacker)

Nr. 34 Demoskopie, Medien und Politik - Ein Schulterschluss mit Risiken und Nebenwirkungen (Thomas Wind)

Nr. 33 Zwischen Fanreportern und Spielverderbern - Fußballjournalismus auf dem Prüfstand (Tonio Postel)

Nr. 32 Unsichere Arbeit - unsichere Mitbestimmung. Die Interessenvertretung atypisch Beschäftigter (Berndt Keller)

Nr. 31 Aufstocker im Bundestag III - Eröffnungsbilanz der Nebenverdienste der Abgeordneten zu Beginn der 19. Wahlperiode (Sven Osterberg)

Nr. 30 Netzwerk AfD. Die neuen Allianzen im Bundestag (Malene Gürgen, Christian Jakob, Sabine am Orde)

Nr. 29 Lindners FDP. Profil - Strategie - Perspektiven (Michael Freckmann)

Nr. 28 Unternehmensteuern in Deutschland. Rechtliche Grauzonen und zivilgesellschaftliche Alternativen (Christoph Trautvetter, Silke Ötsch, Markus Henn)

Nr. 27 Polarisiert und radikalisiert? Medienmisstrauen und die Folgen (Oliver Decker, Alexander Yendell, Johannes Kiess, Elmar Brähler)

Nr. 26 Aufstocker im Bundestag II - Bilanz der Nebenverdienste der Abgeordneten in der 18. Wahlperiode (Sven Osterberg)

Nr. 25 Unterhaltung aus Bayern, Klatsch aus Hessen? Eine Programmanalyse von BR und hr (Eva Spittka, Matthias Wagner, Anne Beier)

Nr. 24 \#MythosTwitter - Chancen und Grenzen eines sozialen Mediums (Mathias König, Wolfgang König) 


\section{Die Otto Brenner Stiftung ...}

... ist die gemeinnützige Wissenschaftsstiftung der IG Metall. Sie hat ihren Sitz in Frankfurt am Main. Als Forum für gesellschaftliche Diskurse und Einrichtung der Forschungsförderung ist sie dem Ziel der sozialen Gerechtig. keit verpflichtet. Besonderes Augenmerk gilt dabei dem Ausgleich zwischen Ost und West.

... initiiert den gesellschaftlichen Dialog durch Veranstaltungen, Workshops und Kooperationsveranstaltungen (z.B. im Herbst die OBS-Jahrestagungen), organisiert Konferenzen, lobt jährlich den „Brenner-Preis für kritischen Journalismus“ aus, fördert wissenschaftliche Untersuchungen zu sozialen, arbeitsmarkt- und gesellschaftspolitischen Themen, vergibt Kurzstudien und legt aktuelle Analysen vor.

... informiert regelmäßig mit einem Newsletter über Projekte, Publikationen, Termine und Veranstaltungen.
... veröffentlicht die Ergebnisse ihrer Forschungsförderung in der Reihe „OBS-Arbeitshefte“ oder als Arbeitspapiere (nur online). Die Arbeitshefte werden, wie auch alle anderen Publikationen der OBS, kostenlos abgegeben. Über die Homepage der Stiftung können sie auch elektronisch bestellt werden. Vergriffene Hefte halten wir als PDF zum Download bereit.

... freut sich über jede ideelle Unterstützung ihrer Arbeit. Aber wir sind auch sehr dankbar, wenn die Arbeit der OBS materiell gefördert wird.

... ist zuletzt durch Bescheid des Finanzamtes Frankfurt am Main V (-Höchst) vom 29. Mai 2018 als ausschließlich und unmittelbar gemeinnützig anerkannt worden. Aufgrund der Gemeinnützigkeit der Otto Brenner Stiftung sind Spenden steuerlich absetzbar bzw. begünstigt.

\section{Unterstützen Sie unsere Arbeit,}

\section{z. B. durch eine zweckgebundene Spende}

Spenden erfolgen nicht in den Vermögensstock der Stiftung, sie werden ausschließlich und zeitnah für die Durchführung der Projekte entsprechend dem Verwendungszweck genutzt.

Bitte nutzen Sie folgende Spendenkonten:

Für Spenden mit zweckgebundenem Verwendungszweck zur Förderung von Wissenschaft und Forschung zum Schwerpunkt:

- Förderung der internationalen Gesinnung und des Völkerverständigungsgedankens

$\begin{array}{ll}\text { Bank: } & \text { HELABA Frankfurt/Main } \\ \text { IBAN: } & \text { DE11 5005 } 00000090546003 \\ \text { BIC: } & \text { HELA DE FF }\end{array}$

Für Spenden mit zweckgebundenem Verwendungszweck zur Förderung von Wissenschaft und Forschung zu den Schwerpunkten:

- Angleichung der Arbeits- und Lebensverhältnisse in Ost- und Westdeutschland (einschließlich des Umweltschutzes)

- Entwicklung demokratischer Arbeitsbeziehungen in Mittel- und Osteuropa

- Verfolgung des Zieles der sozialen Gerechtigkeit

$\begin{array}{ll}\text { Bank: } & \text { HELABA Frankfurt/Main } \\ \text { IBAN: } & \text { DE86 5005 0000 } 0090546011 \\ \text { BIC: } & \text { HELA DE FF }\end{array}$

Geben Sie bitte Ihre vollständige Adresse auf dem Überweisungsträger an, damit wir Ihnen nach Eingang der Spende eine Spendenbescheinigung zusenden können. Oder bitten Sie in einem kurzen Schreiben an die Stiftung unter Angabe der Zahlungsmodalitäten um eine Spendenbescheinigung. Verwaltungsrat und Geschäftsführung der Otto Brenner Stiftung danken für die finanzielle Unterstützung und versichern, dass die Spenden ausschließlich für den gewünschten Verwendungszweck genutzt werden.

\section{Aktuelle Ergebnisse der Forschungsförderung} in der Reihe „OBS-Arbeitshefte“

\section{OBS-Arbeitsheft 103}

Ingo Dachwitz, Alexander Fanta

Medienmäzen Google

Wie der Datenkonzern den Journalismus umgarnt

\section{OBS-Arbeitsheft 102*}

Wolfgang Schroeder, Samuel Greef u.a.

Bedrängte Zivilgesellschaft von rechts

Interventionsversuche und Reaktionsmuster

\section{OBS-Arbeitsheft 101*}

Leif Kramp, Stephan Weichert

Nachrichten mit Perspektive

Lösungsorientierter und konstruktiver Journalismus in Deutschland

\section{OBS-Arbeitsheft 100*}

Tim Engartner

Wie DAX-Unternehmen Schule machen

Lehr- und Lernmaterial als Türöffner für Lobbyismus

\section{- OBS-Arbeitsheft 99*}

Tobias Gostomzyk, Daniel Moßbrucker

„Wenn Sie das schreiben, verklage ich Sie!“

Studie zu präventiven Anwaltsstrategien

gegenüber Medien

\section{OBS-Arbeitsheft 98*}

Lutz Frühbrodt, Annette Floren

Unboxing YouTube

Im Netzwerk der Profis und Profiteure

OBS-Arbeitsheft $97^{*}$

Wolfgang Schroeder, Stefan Fuchs

Neue Mitglieder für die Gewerkschaften

Mitgliederpolitik als neues Politikfeld der IG Metall

\section{OBS-Arbeitsheft 96*}

Rainer Faus, Simon Storks

Im vereinten Deutschland geboren -

in den Einstellungen gespalten?

OBS-Studie zur ersten Nachwendegeneration

- OBS-Arbeitsheft $95^{*}$

Bernd Gäbler

AfD und Medien

Erfahrungen und Lehren für die Praxis

OBS-Arbeitsheft $94^{*}$

Olaf Hoffjahn, Oliver Haidukiewicz

Deutschlands Blogger

Die unterschätzten Journalisten

\section{OBS-Arbeitsheft 93*}

Michael Haller

Die „Flüchtlingskrise“ in den Medien

Tagesaktueller Journalismus zwischen

Meinung und Information

* Printfassung leider vergriffen; Download weiterhin möglich. 


\section{OBS-Arbeitsheft 103}

\section{Google, the media patron}

How the digital giant ensnares journalism

www.otto-brenner-stiftung.de 